\title{
Rekam Kesehatan Elektronik
}

Kajian Model dan Prototipe Sistem Informasi Kesehatan untuk Industri 4.0

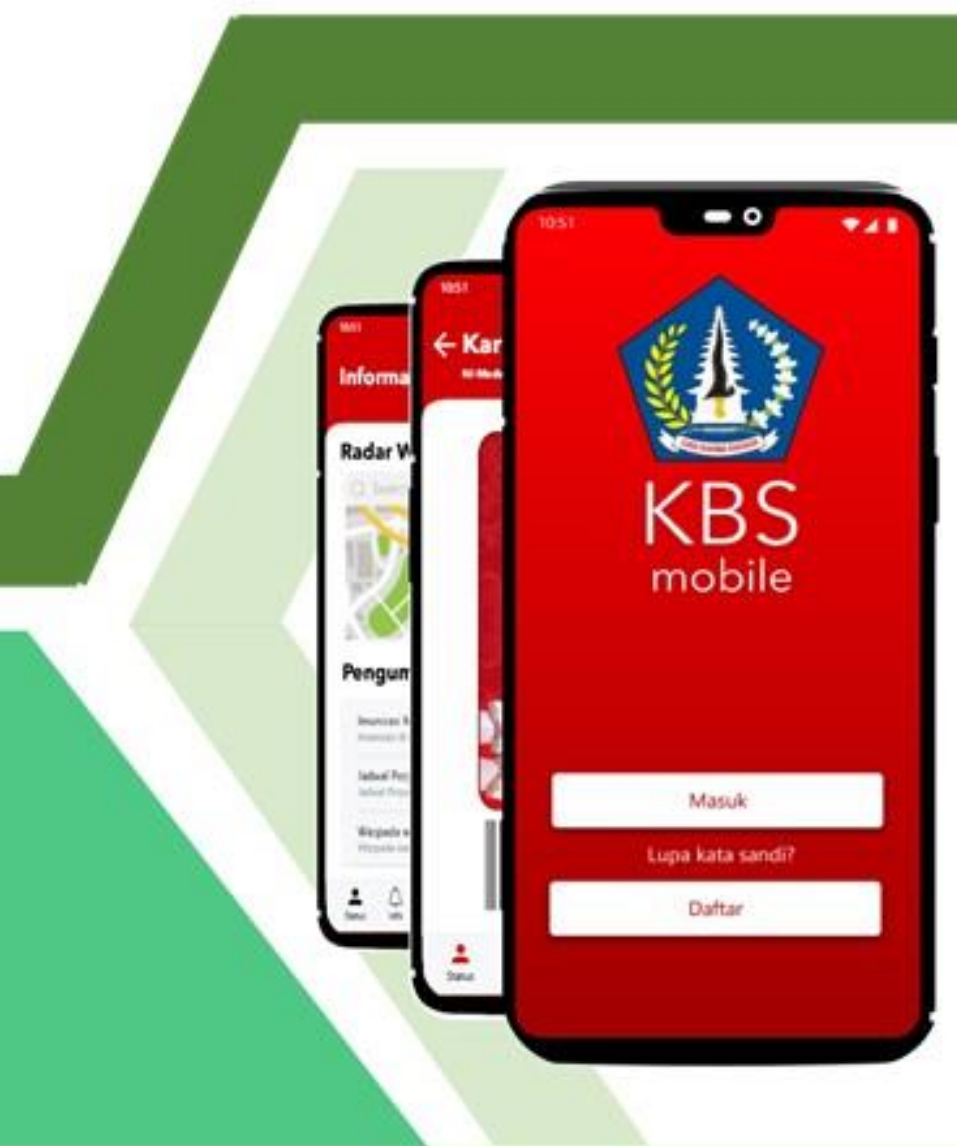




\section{Rekam Kesehatan Elektronik Kajian Model dan Prototipe Sistem Informasi Kesehatan untuk Industri $\mathbf{4 . 0}$}

\section{Penulis:}

Pande Putu Januraga

Gede Benny Setia Wirawan

Ngakan Putu Anom Harjana

Ni Putu Sintia Ulandari

\section{PENERBIT}

PANUDUH ATMA WARAS

Jl. ByPass Ngurah Rai Nomor: 888 xx, Denpasar, Bali - Indonesia (0361) 6209990 (+62)82236180725

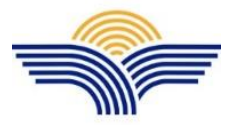

info@baswarapress.com

panuduhatmawaras@gmail.com 


\section{Rekam Kesehatan Elektronik Kajian Model dan Prototipe Sistem Informasi Kesehatan untuk Industri 4.0}

\section{Penulis:}

Pande Putu Januraga

Gede Benny Setia Wirawan

Ngakan Putu Anom Harjana

Ni Putu Sintia Ulandari

ISBN (PDF): 978-623-97473-2-9

Copyright (C) Agustus 2021

Hak Cipta dilindungi oleh Undang-Undang. Pertama kali diterbitkan di Indonesia dalam Bahasa Indonesia oleh PANUDUH ATMA WARAS. Penggunaan material dalam karya ini diatur dalam Lisensi Publik Creative Commons 4.0 Atribusi-NonKomersialTanpaTurunan (CC-BY-ND). Pengguna dapat mengutip konten dalam karya ini dengan memberi kredit yang sepantasnya kepada penulis asli karya ini. Dilarang menggunakan karya ini untuk kepentingan komersial dalam bentuk apapun. Dilarang mengubah dan menyebarluaskan isi karya ini dalam bentuk apa pun tanpa izin tertulis dari penulis.

\section{PENERBIT}

PANUDUH ATMA WARAS

Jl. ByPass Ngurah Rai Nomor: 888 xx, Denpasar, Bali - Indonesia (0361) 6209990; (+62)82236180725

info@baswarapress.com

panuduhatmawaras@gmail.com 


\section{Kata Pengantar}

Om Swastiastu.

Dunia, dan Indonesia, sedang melalui Revolusi Industri 4.0. Teknologi informasi berkembang pesat. Dewasa ini, perkembangan teknologi telah mendorong digitalisasi beberapa sistem layanan kesehatan. Salah satu contoh yang paling kongkrit adalah penerapan rekam medis elektronik (electronic medical record/EMR) dalam layanan kesehatan di berbagai fasilitas. Dari sisi pasien atau masyarakat individualized medicine adalah konsep sedang pesat berkembang. Dalam hal pemerintahan, konsep big data digunakan sebagai penuntun dalam pengambilan kebijakan strategis.

Dalam iklim perkembangan teknologi seperti ini, kami menyambut kerja sama yang dilakukan antara Center for Public Health Innovation (CPHI) dari Fakultas Kedokteran Universitas Udayana dengan Pemerintah Daerah Kabupaten Badung dalam pengembangan model sistem rekam medis kesehatan elektronik atau electronic personal health record (E-PHR) ini. Diharapkan kajian ini dapat menjadi rujukan bagi para pemangku kebijakan dan pengambil keputusan strategis dan juga menjadi rujukan bagi akademisi yang bergerak dalam bidang kesehatan dan teknologi informasi kesehatan.

Akhir kata, saya mengucapkan selamat pada peneliti di CPHI, Fakultas Kedokteran Universitas Udayana dan juga Bupati Badung dan jajarannya di Pemerintah Daerah Kabupaten Badung atas rampungnya kajian mengenai pengembangan model rekam kesehatan elektronik atau E-PHR ini.

Om Shanti Shanti Shanti Om.

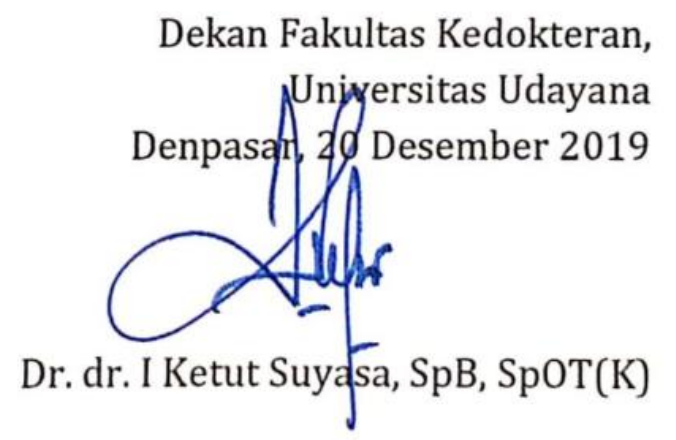




\section{Daitar Isí}

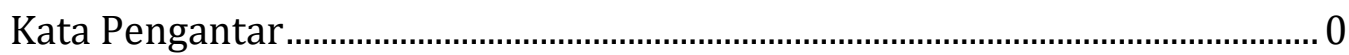

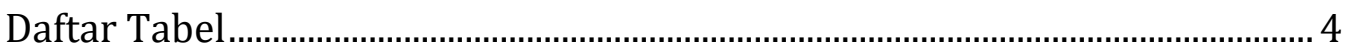

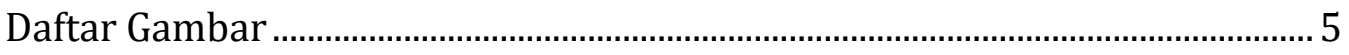

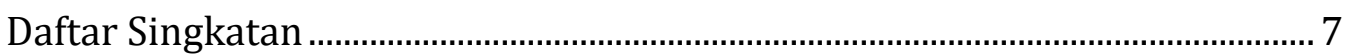

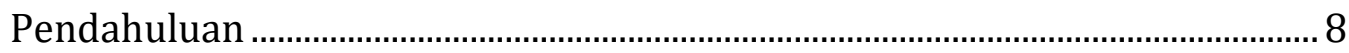

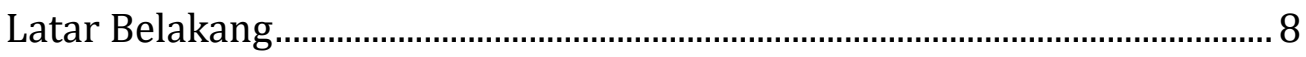

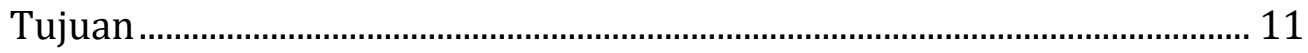

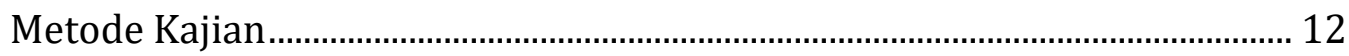

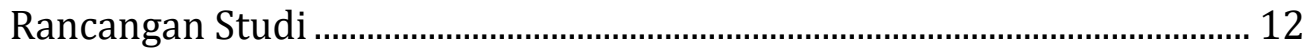

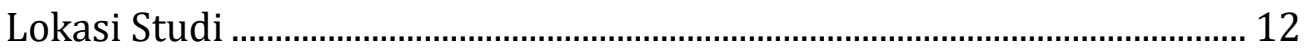

Tahapan Studi ..................................................................................... 12

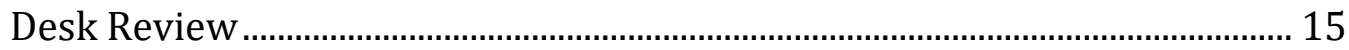

Latar Belakang Pengembangan E-PHR ....................................................... 15

Model dan Arsitektur Sistem E-PHR ............................................................. 16

Cakupan Perekaman Informasi.................................................................... 18

Evaluasi dan Indikator Keberhasilan Sistem E-PHR...................................... 21

Perbandingan Model E-PHR......................................................................... 23

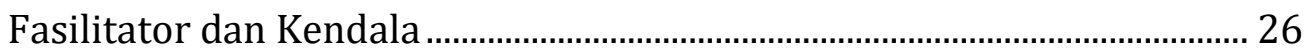

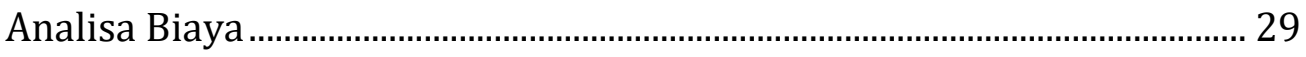

Pengembangan E-PHR untuk Promosi Kesehatan ......................................... 31

Studi Kasus Implementasi E-PHR di Australia................................................. 35

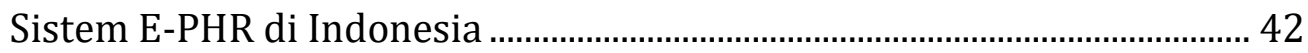

Feasibilitas penerapan E-PHR................................................................... 50

Kelayakan Produk (Product feasibility) .......................................................... 50

Kelayakan Pasar (Market feasibility) .......................................................... 74

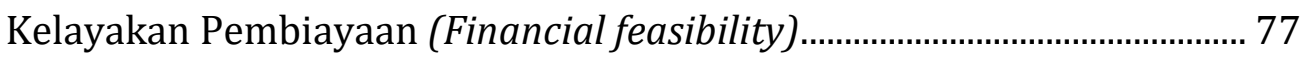

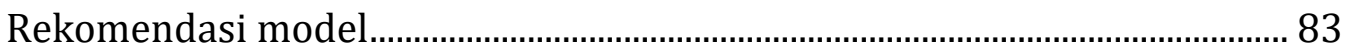

Ucapan Terima Kasih...................................................................................110

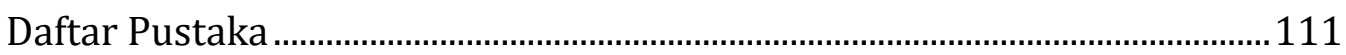




\section{Daitar Tabel}

Tabel 1. Instrumen kajian penerapan E-PHR.................................................13

Tabel 2. Rangkuman jenis informasi yang tersedia.........................................20

Tabel 3. Kendala-kendala Pengembangan dan Adopsi ...................................28

Tabel 4. Tingkat akses pengguna MyHR ............................................................39

Tabel 5. Peraturan yang relevan dalam pengembangan ................................44

Tabel 6. Peraturan yang relevan dalam akses informasi ................................45

Tabel 7. Faktor-faktor fasilitator dan kendala..............................................48

Tabel 8. Kekuatan dan kelemahan e-Puskesmas............................................50

Tabel 9. Kekuatan dan kelemahan P-Care.......................................................57

Tabel 10. Kekuatan dan kelemahan V-Claim ...............................................61

Tabel 11. Kekuatan dan kelemahan Mobile JKN............................................63

Tabel 12. Kekuatan dan kelemahan Krama Bali Sehat..................................67

Tabel 13. Fitur-fitur dalam Krama Bali Sehat Provinsi Bali...........................68

Tabel 14. Perhitungan biaya pengembangan E-PHR .....................................78

Tabel 15. Budgeting Maintanace Sistem E-PHR .............................................81

Tabel 16. Budgeting Operasional Sistem E-PHR ............................................81

Tabel 17. Prediksi Total Kebutuhan Biaya ....................................................82

Tabel 18. Kebutuhan Personil untuk Pengembangan Sistem .................... 104 


\section{Daitar Gambar}

Gambar 1. Ilustrasi arus informasi dalam sistem E-PHR ................................18

Gambar 2. Arus informasi dalam sistem E-PHR Denmark ...........................24

Gambar 3. Alur arus informasi HealthConnect Australia. .............................25

Gambar 4. Tampilan aplikasi WYhealth Due Date Plus ...................................32

Gambar 5. Ilustrasi arus informasi dalam HealthVault .................................34

Gambar 6. Arsitektur sistem sistem E-PHR Australia .....................................37

Gambar 7. Tampilan akun pengguna MyHR saat rilis ....................................38

Gambar 8. Tampilan pendaftaran pasien baru di e-Puskesmas....................51

Gambar 9. Tampilan laman antrian sistem e-Puskesmas................................52

Gambar 10. Tampilan laman awal layanan ....................................................53

Gambar 11. Flagging penyakit khusus dan riwayat kunjungan.....................53

Gambar 12. Sub-laman anamnesis dalam laman layanan...............................54

Gambar 13. Sub-laman body map interaktif ..............................................55

Gambar 14. Laman diagnosis pasien dalam e-Puskesmas.............................55

Gambar 15. Laman peresepan obat dan tindakan medis ..............................56

Gambar 16. Tampilan laman awal PCare BPJS Kesehatan .............................58

Gambar 17. Tampilan layanan pendaftaran dalam PCare..............................59

Gambar 18. Tampilan layanan rekam medis terbatas PCare .........................60

Gambar 19. Tampilan riwayat kunjungan pasien.........................................61

Gambar 20. Tampilan laman pembuatan SEP VClaim ...................................62

Gambar 21. Laman awal sebelum registrasi aplikasi ......................................64

Gambar 22. Tampilan menu peserta dan pelayanan ........................................65

Gambar 23. Tampilan riwayat pelayanan dan review layanan ....................66

Gambar 27. Rancangan Model Sistem E-PHR dalam KBS...............................85

Gambar 28. Halaman Login dan Pendaftaran KBS Mobile .............................90

Gambar 29. Dashboard dan Halaman Status KBS Mobile................................91

Gambar 30. Catatan Medis pada Aplikasi KBS Mobile .....................................92

Gambar 31. Fasilitas Kesehatan pada Aplikasi KBS Mobile............................93

Gambar 32. Halaman informasi kesehatan KBS Mobile..................................94

Gambar 33. Fitur chat pada Aplikasi KBS Mobile ..........................................95

Gambar 34. Tampilan halaman login pada KBS Vision...................................96

Gambar 35. Tampilan dashboard pada KBS Vision...........................................97

Gambar 36. Tampilan Pencarian Data Pasien pada Dashboard ...................98 
Gambar 37. Tampilan Registrasi Pelayanan pada Dashboard......................99

Gambar 38. Tampilan Menu Pasien pada KBS Vision .................................... 100

Gambar 39. Menu Catatan Medis Pasien ........................................................ 100

Gambar 40. Menu Informasi Kesehatan ....................................................... 101

Gambar 41. Tampilan Menu Informasi Kesehatan......................................... 102

Gambar 42. Menu Kesehatan Ibu dan Anak (KIA) ........................................... 103

Gambar 43. Fitur Radar Wabah ...................................................................... 103 


\section{Daitar Singkatan}

$\begin{array}{ll}\text { E-PHR } & \text { : Electronic Personal Health Record } \\ \text { PHR } & \text { : Personal Health Record } \\ \text { eHR } & : \text { Electronic Health Record } \\ \text { EMR } & : \text { Electronic Medical Record } \\ \text { JKN } & \text { : Jaminan Kesehatan Nasional } \\ \text { UHC } & : \text { Universal Health Coverage } \\ \text { KBS } & : \text { Krama Badung Sehat } \\ \text { APBD } & : \text { Anggaran Pendapatan dan Belanja Daerah } \\ \text { PBI } & : \text { Penerima Bantuan Iuran } \\ \text { BPJS Kesehatan } & : \text { Badan Penyelenggara Jaminan Sosial Kesehatan } \\ \text { Diskominfo } & : \text { Dinas Komunikasi dan Informatika } \\ \text { Disdukcapil } & : \text { Dinas Kependudukan dan Catatan Sipil } \\ \text { FGD } & : \text { Focus Group Discussion } \\ \text { IT } & : \text { Information Technology } \\ \text { MyHR } & : \text { My Health Record } \\ \text { FKTP } & : \text { Fasilitas Kesehatan Tingkat Pertama } \\ \text { FKRTL } & : \text { Fasilitas Kesehatan Rujukan Tingkat Lanjutan }\end{array}$




\section{Pendahuluan}

\section{Latar Belakang}

Perkembangan teknologi digital dan internet membawa banyak dampak pada kehidupan masyarakat, salah satunya pada bidang kesehatan. Bebasnya penyebaran informasi melalui internet menyebabkan bergesernya tren pada masyarakat dalam mengakses informasi kesehatan. Sebelum berkembangnya internet, informasi terkait kesehatan hanya bisa diperoleh dari praktisi kesehatan. Saat ini, masyarakat sudah bisa mengakses informasi melalui internet terkait dengan gejala penyakit, keluhan, hingga metode pengobatan terhadap sakit yang dideritanya. Di sisi lain, kecanggihan teknologi ini juga menyebabkan masyarakat cenderung ingin sesuatu yang serba praktis, termasuk dalam mengakses layanan kesehatan. Hal ini mendorong semakin banyaknya teknologi digital yang berkembang dalam layanan kesehatan guna memenuhi tuntutan kebutuhan masyarakat tersebut.

Electronic Medical Record (EMR) atau yang lebih dikenal dengan sebutan rekam medis elektronik adalah salah satu teknologi yang berkembang dalam bidang kesehatan. Rekam medis adalah suatu keterangan baik yang tertulis maupun terekam terkait identitas, anamnesa, penentuan fisik, laboratorium, diagnosa segala pelayanan, dan tindakan medis yang diberikan kepada pasien. Di Indonesia, penerapan EMR sudah dilakukan pada sebagian besar rumah sakit karena telah memberikan banyak kemudahan serta manfaat bagi pelayanan kesehatan. Sistem catatan medis yang terintegrasi dan terkomputerisasi menyebabkan pelayanan kesehatan menjadi lebih efektif dan efisien dalam memberikan pelayanan kesehatan kepada masyarakat.

Meskipun memberikan banyak kemudahan, penerapan EMR dinilai masih belum berjalan dengan efektif karena belum semua fasilitas kesehatan mampu menerapkannya. Setiap rumah sakit memiliki sistem EMR tersendiri dan belum bisa terintegrasi dengan rumah sakit atau fasilitas kesehatan lainnnya dalam hal penyediaan data pasien. Hal ini akan menjadi masalah jika pasien berpindah-pindah dalam berobat. Data rekam medis yang tercatat pada rumah sakit sebelumnya tidak akan bermanfaat 
karena rumah sakit tempat pasien berobat berikutnya tidak memiliki akses terhadap data rekam medis pasien tersebut.

Di era penerapan Jaminan Kesehatan Nasional (JKN) seperti saat ini, keberadaan teknologi EMR sangat bermanfaat terutama dalam perhitungan pembiayaan kesehatan yang diperlukan. Upaya pembiayaan melalui JKN adalah upaya pemerintah untuk menjamin seluruh warga negara memperoleh akses ke pelayanan kesehatan sesuai dengan kebutuhan dan berkeadilan (Universal Health Coverage-UHC). Pelayanan kesehatan pada era JKN seperti saat ini tidak hanya berfokus pada upaya pengobatan, tetapi juga mengutamakan upaya preventif dan promotif (pencegahan). Oleh sebab itu, di era JKN masyarakat akan didorong untuk berperan aktif dalam mengelola kesehatannya sehingga dapat terhindar dari penyakit.

Meskipun era JKN memberi ruang kepada pasien untuk berpartisipasi aktif dalam menjaga kesehatannya, pasien belum bisa memanfaatkan layanan dengan optimal, terutama dalam pengelolaan data kesehatan pribadi. Hal ini dikarenakan belum adanya sarana bagi pasien untuk bisa mengakses data kesehatan dasar yang sudah tersimpan di EMR masing-masing layanan kesehatan. Data kesehatan dasar yang dimaksud seperti riwayat pengobatan, riwayat imunisasi, serta beberapa data kesehatan dasar lain yang penting untuk diketahui oleh pasien. Idealnya, pasien hendaknya dapat mengakses informasi kesehatan pribadinya kapan saja dan di mana saja sehingga memudahkan petugas kesehatan untuk memberikan pelayanan. Oleh sebab itu, perlu dikembangkan suatu sistem yang dapat menjembatani antara pelayanan kesehatan dengan pasien, sehingga data-data kesehatan dasar pasien yang terekam pada EMR di masing-masing layanan agar bisa diakses oleh pasien. Salah satu sistem yang dapat dikembangkan untuk menjembatani antara pasien dengan layanan kesehatan adalah rekam kesehatan elektronik atau Electronic Personal Health Record (E-PHR).

Selain sebagai jembatan antara komponen EMR dan pasien sebagai pengguna, penggunaan rekam kesehatan elektronik juga membuka peluang yang sangat besar bagi pemangku kebijakan publik. Seperti diketahui, saat ini dunia memasuki Revolusi Industri 4.0 yaitu revolusi teknologi informasi. Informasi, atau data, telah menjadi komoditas yang sangat berharga dan data science serta konsep big data telah digunakan berbagai perusahaan 
untuk mengambil keputusan strategis yang membantu mereka mengembangkan perusahaannya.

Di sisi lain, pemerintah justru terlambat untuk menjajal tekonologi big data dan data science ini. Sebagai regulator dan pemangku kebijakan, pemerintah memiliki potensi data yang sangat besar yang dikumpulkan melalui jenjang-jenjang birokrasi pemerintahan. Akan tetapi, informasi ini tidak dapat dioptimalkan untuk diolah dalam konsep big data untuk menarik kebijakan public yang didasari bukti empiris.

Rekam kesehatan elektronik atau E-PHR yang dikelola pemerintah dapat membantu pemerintah mengoptimalkan potensi informatika yang besar ini. E-PHR atau rekam kesehatan elektronik dapat berfungsi sebagai modalitas pengumpul data individual dari seluruh masyarakat. Database yang dihasilkan dapat diolah untuk membantu pemerintah mengembangkan kebijakan-kebijakan publik di bidang kesehatan yang didasari data empiris sehingga diharapkan lebih efektif. Pemerintah juga dapat menggunakan database ini untuk melakukan pemetaan risiko kesehatan, sehingga dapat mengantisipasi masalah-masalah kesehatan masyarakat yang dapat terjadi. Lebih lanjut lagi, pemerintah dapat meniru yang dilakukan perusahaan-perusahaan seperti Google dan Facebook yang menggunakan alogritma berdasarkan big data untuk menyajikan iklan-iklan layanan masyarakat yang tepat sasaran pada lapisan-lapisan masyarakat yang paling membutuhkan.

Saat ini, kami berkesempatan mengembangkan suatu model rekam kesehatan elektronik untuk Pemerintah Daerah Kabupaten Badung. Kabupaten Badung adalah salah satu daerah di Provinsi Bali yang sudah aktif memperjuangkan tercapainya UHC bagi masyarakatnya. Tidak hanya untuk mendukung tercapainya program nasional JKN, Pemerintah Kabupaten Badung juga berupaya mewujudkan visi dan misi pembangunan daerah yaitu meningkatkan kualitas kesehatan masyarakat melalui Program Krama Badung Sehat (KBS). Program KBS adalah jaminan pelayanan kesehatan yang diberikan kepada seluruh penduduk Kabupaten Badung dengan perolehan manfaat dibagi menjadi (1) Seluruh penduduk Kabupaten Badung yang belum menjadi peserta Jaminan Kesehatan Nasional (JKN) sebagai Penerima Biaya Iuran (PBI) APBD; (2) Seluruh penduduk Kabupaten Badung yang sudah memiliki JKN agar dapat memperoleh 
manfaat tambahan selain manfaat yang sudah diterima dari JKN; (3) Seluruh penduduk Kabupaten Badung yang belum memiliki JKN karena belum terdaftar, bayi baru lahir, atau karena pernikahan; dan terakhir (4) Seluruh penduduk Kabupaten Badung peserta JKN Mandiri yang tidak aktif.

Sebelum sebuah sistem besar seperti rekam kesehatan elektronik atau E-PHR ini dikembangkan, terlebih dahulu harus disusun arsitektur sistem yang ideal dan sesuai dengan kondisi di mana sistem ini akan diterapkan. Sistem yang disusun ini harus mampu mencapai fungsi dan tujuan utama sistem E-PHR yaitu 1) sebagai jembatan antara informasi dalam EMR dan pasien sebagai pemilik informasi dan 2) memberdayakan pasien untuk mengelola kesehatannya sendiri sebagai individual. Selain itu, sistem ini pun harus mencapai cita-cita inisiator sistem, dalam kesempatan ini adalah Kabupaten Badung, yaitu menghasilkan UHC dengan added value atau nilai tambah dibandingkan dengan yang diperoleh dari sistem Jaminan Kesehatan Nasional (JKN) standar. Berdasarkan cita-cita ini, kami melakukan kajian situasi Kabupaten Badung dan, berdasarkan data yang tersedia, menyusun model sistem rekam kesehatan elektronik yang ideal untuk situasi yang tersedia.

\section{Tujuan}

Memepertimbangkan rekomendasi berdasarkan hasil evaluasi pelaksanaan Program KBS tahun 2018 serta mengidentifikasi potensi penerapan teknologi terkini guna peningkatan kualitas pelayanan Program KBS, maka kegiatan kajian ini bertujuan untuk:

a. Menyusun Model Elektronic Personal Health Record (E-PHR) yang sesuai dengan kebutuhan Pelayanan Kesehatan

b. Mengkaji Kebutuhan Biaya Minimal Pengembangan Elektronic Personal Health Record (E-PHR) sesuai dengan Model yang dirumuskan. 


\section{Metode Kajian}

\section{Rancangan Studi}

Kajian penerapan E-PHR dirancang sebagai studi kuantitatif dan kualitatif yang bersifat deskriptif dengan menggunakan kelompok beneficiary seperti pemerintah daerah dalam hal ini Dinas Kesehatan Kabupaten Badung, fasilitas kesehatan, dokter pemberi layanan, serta masyarakat sebagai populasi target. Data yang dikumpulkan meliputi dokumen pendukung penerapan sistem E-PHR, dokumen ketersediaan sarana dan prasarana pendukung sistem E-PHR, dokumen ketersediaan sumber daya manusia pendukung penerapan sistem E-PHR, dan data primer hasil wawancara berupa data kualitatif di fasilitas kesehatan serta kelompok masyarakat.

\section{Lokasi Studi}

Kajian secara kualitatif dilakukan melalui wawancara mendalam pada 6 orang serta melalui Focus Group Discussion (FGD) pada 89 orang. Data kualitatif terutama menyaring pendapat, persepsi, serta aspirasi para stakeholder mengenai sistem rekam kesehatan elektronik yang akan dikembangkan. Informasi yang disaring berupa aspirasi mengenai fitur dan isi dari sistem yang dianggap ideal serta kekhawatiran dan harapan yang dimiliki mengenai penerapan sistem E-PHR ini. Wawancara mandalam dilakukan pada 2 orang dari Dinas Kesehatan Kabupaten Badung, 2 orang dari Dinas Komunikasi dan Informasi, 1 orang dari BPJS Kesehatan, serta 1 orang dari Dinas Kependudukan. Sedangkan FGD dilakukan pada 12 orang perwakilan dokter umum/gigi pemberi layanan di rumah sakit, 15 orang perwakilan dokter umum/gigi pemberi layanan di FKTP, 6 orang dokter umum praktik mandiri, 6 orang dokter gigi praktik mandiri, 25 orang kelompok masyarakat pedesaan (Desa Carangsari), serta 25 orang kelompok masyarakat perkotaan (Kelurahan Kuta).

\section{Tahapan Studi}

Tahapan pelaksanaan kajian kesiapan penerapan E-PHR ini dimulai dari desk review, pengembangan instrument kuantitatif dan kualitatif, persiapan pengumpulan data, pengumpulan data, analisis data, 
pengembangan prototipe E-PHR, uji coba prototipe E-PHR, dan penyusunan laporan. Pelaporan dilakukan dalam dua tahap, yaitu laporan pendahuluan dan laporan akhir.

\section{A. Desk Review}

Analisis terhadap beberapa penelitian dan prototipe E-HPR yang sudah diterapkan di beberapa negara dilakukan untuk mengidentifikasi sistem E-PHR yang cocok diterapkan di Kabupaten Badung.

\section{B. Pengembangan Instrumen}

Instrumen dikembangkan dengan memerhatikan ketersediaan data di tempat pengumpulan data. Berikut adalah instrument kajian kesiapan penerapan E-PHR:

Tabel 1. Instrumen kajian penerapan E-PHR

\section{Instrumen Kualitatif}

1 Wawancara mendalam dengan Dinas Kesehatan, BPJS Kesehatan, Kominfo, Disdukcapil, dan pemberi pelayanan kesehatan (di puskesmas, rumah sakit, klinik, dokter umum, dan dokter gigi) serta instrument FGD untuk masyarakat

\section{Pengumpulan Data}

Pengumpulan data primer berupa data kualitatif dilakukan dengan in depth interview (IDI) atau wawancara mendalam dan juga focused group discussion (FGD) dengan berbagai stakeholder yang akan terpengaruh dari pengembangan E-PHR di Kabupaten Badung. Diskusi dan wawancara mendalam direkam lalu ditelurkan dalam bentuk transcript atau notulensi yang kemudian dianalisa secara kualitatif untuk dapat menyaring inti-inti ide yang relevan dalam pengembangan E-PHR.

\section{Pengolahan dan Analisis Data}

Data kualitatif dari wawancara mendalam serta FGD dianalisis secara kualitiatif dengan menggunakan metode tematik analisis. Seluruh data yang dihasilkan kemudian digunakan untuk menyusun rancangan model sistem E-PHR yang cocok diterapkan sesuai dengan kondisi di Kabupaten Badung. Rancangan model sistem E-PHR ini bermanfaat untuk proses perencanaan untuk pengembangan maupun implementasi sistem E-PHR di Kabupaten 
Badung di masa yang akan datang guna meningkatkan kualitas layanan Program KBS. 


\section{Desk Review}

\section{Latar Belakang Pengembangan E-PHR}

Terdapat beberapa pertimbangan dalam pengembangan sistem EPHR dalam satu negara atau komunitas kesehatan lainnya. Salah satu pertimbangan yang paling sederhana adalah keniscayaan. Perkembangan teknologi informasi telah memicu komputerisasi berbagai sistem kesehatan, mulai sistem rekam medis, hingga alat-alat kesehatan seperti alat laboratorium bahkan alat-alat pemeriksaan fisis. Beberapa pelaku kesehatan menganggap komputerisasi berbagai sektor kesehatan yang terjadi secara sporadic dapat menjadi masalah di masa depan akibat kurangnya integrasi informasi kesehatan yang dihasilkan. Pengembangan sistem eHR, yang dibarengi dengan sistem PHR menjadi E-PHR, dianggap sebagai keniscaayan dan keharusan dalam rangka menyikapi komputerisasi berbagai aspek layanan kesehatan yang tidak terbendung (Pearce and Bainbridge, 2014).

Dalam pengembangan sistem E-PHR di Australia, Pearce dan Bainbridge (2014) juga menyatakan pergeseran paradigma layanan kesehatan menjadi salah satu alasannya. Dalam paradigma layanan kesehatan yang baru, hubungan antara penyedia layanan kesehatan dan pasien adalah hubungan kemitraan yang setara. Dalam hubungan kemitraan yang setara, diperlukan kesetaraan dalam akses terhadap informasi mengenai masalah yang akan dipecahkan, dalam hal ini masalah kesehatan dari pasien itu sendiri. Oleh karena itu, pasien diharapkan untuk mengerti masalah kesehatan setidaknya mengenai kesehatannya sendiri. Meningkatkan akses pasien terhadap informasi kesehatan pribadinya dan mempermudah komunikasi informasi tersebut antara penyedia layanan kesehatan satu dan penyedia layanan kesehatan lain melalui E-PHR dilihat sebagai salah satu pendorong pengembangan E-PHR, termasuk di Australia (Pearce and Bainbridge, 2014).

Selain alasan-alasan filosofis di atas, terdapat juga alasan-alasan pragmatis dalam pengembangan sistem E-PHR. Komunikasi antar penyedia layanan kesehatan merupakan aspek penting dalam menyediakan layanan kesehatan yang berkualitas bagi pasien. Dalam hal ini, komunikasi 
tradisional yang dilakukan secara tertulis memiliki kelemahan tersendiri. Sudah menjadi rahasia umum bahwa kesalahan medis dapat terjadi akibat kesalahan dalam membaca dan menulis rekam medis ataupun sarana komunikasi antar penyedia layanan kesehatan tertulis lainnya. Selain itu, waktu juga dapat terbuang dalam proses pembuatan dan ekstraksi informasi dari rekam medis tertulis. Dalam hal ini, pengembangan eHR dinilai sebagai solusi atas masalah tersebut. eHR yang terintegrasi memiliki keunggulan dalam hal akses tenaga medis terhadap informasi yang terkandung dalamnya, kemudahan pembuatan, dan kemudahan memindahkan informasi ini antara tenaga medis satu dan lainnya (Gunter and Terry, 2005).

Pengembangan E-PHR terkait dengan keunggulan dari eHR tersebut. Dalam prinsip etika kesehatan, informasi dalam sistem eHR tetap menjadi milik pasien. Oleh karena itu, pemberian kuasa pada pasien atas akses terhadap informasi dalam eHR menjadi keniscayaan (Gunter and Terry, 2005). Selain itu, integrasi pasien dalam sistem eHR menjadi sistem E-PHR ini juga diperkirakan dapat menghemat dana secara signifikan melalui peningkatan efisiensi sistem pendaftaran, perujukan, dan peresepan obat terhadap pasien (Kaelber and Pan, 2008).

\section{Model dan Arsitektur Sistem E-PHR}

Terdapat beberapa paradigma mengenai Electronic Personal Health Record (E-PHR). Paradigma dari 10 tahun yang lalu masih mengklasifikasikan electronic health record (eHR) dan personal health record (PHR) sebagai dua konsep berbeda. Sedangkan penelitian lain mendefinisikan PHR sebagai sistem informasi kesehatan dan rekam medis di mana kontrol atas informasi dan rekam medis berada pada individual pasien atau pengguna layanan informasi kesehatan dan rekam medis tersebut (Tang et al., 2006). Sementara itu, Gunter dan Terry (2005) mendefinisikan eHR sebagai suatu sistem informasi kesehatan dan rekam medis yang berbasis platform elektronik.

Dari dua definisi ini, kita dapat melihat konsep dan PHR dan eHR menekankan pada dua aspek berbeda: PHR menekankan pada kontrol individual atas arus dan akses informasi mengenai kesehatannya sendiri sementara eHR menekankan pada metode penyimpanan dan pengaturan 
arus informasi tersebut dengan menggunakan sarana dan prasarana elektronik. Pada perkembangannya, dengan kemajuan teknologi informasi. Dalam paradigm terbaru, PHR dan eHR dilihat sebagai dua ekstrem dari spektrum teknik pengelolaan informasi kesehatan di mana eHR dilihat sebagai sistem yang memberikan kontrol pada penyedia layanan kesehatan dan PHR sebagai sistem yang memberi kontrol pada individu sebagai pengguna layanan kesehatan (ISO, 2012).

Pendekatan ini kemudian berkembang untuk menggunakan sarana dan prasarana elektronik, menggabungkan konsep PHR dan eHR menjadi Electronic Personal Health Record (E-PHR) (Quaini et al., 2018). Dalam pemodelan E-PHR ini, PHR dan eHR dapat berfungsi secara beriringan. Informasi kesehatan dari sistem eHR masing-masing layanan kesehatan digabungkan dengan informasi kesehatan yang dimasukkan oleh individual pasien sendiri melalui piranti elektronik seperti komputer, laptop, atau smartphone kemudian disajikan kepada pengguna yang memiliki kontrol atas informasi individual ini (Quaini et al., 2018).

Pemodelan dan arsitektur model E-PHR yang berkembang dapat diklasifikasi menjadi 3 jenis: E-PHR yang berdiri sendiri, E-PHR yang terikat dengan sistem eHR dan eMR, dan E-PHR yang dikelola pihak ketiga (Kaelber and Pan, 2008). Klasifikasi ini memandang PHR dan EHR sebagai dua komponen terpisah dari sistem informasi kesehatan di mana PHR merupakan komponen informatika kesehatan yang menyajikan informasi rekam medis dan riwayat kesehatan ke pasien dan EHR merupakan komponen yang menyajikan informasi pada penyedia layanan kesehatan dan memfasilitasi komunikasi antar-penyedia layanan kesehatan. Pada EPHR dengan arsitektur yang berdiri sendiri, sistem PHR tidak terhubung dengan sistem EHR dari penyedia layanan kesehatan. Informasi, seperti rekam medis dan hasil pemeriksaan penunjang, harus dimasukkan secara manual oleh pasien sebagai pengguna layanan kesehatan. Pada arsitektur terikat (tethered), informasi yang dimasukkan ke dalam sistem EHR secara ototmatis tersaji dalam sistem PHR, tanpa kecuali. Titik tengah antara arsitektur berdiri sendiri (standalone) dan terikat adalah arsitektur terhubung (interconnected) di mana informasi yang dimasukkan ke dalam EHR secara otomatis tersaji pada PHR, akan tetapi pasien sebagai pengguna dapat menambah atau mengurangi informasi dalam PHR itu sendiri. 
Sementara itu, pada arsitektur pihak ketiga informasi dari sistem EHR dan PHR disimpan, dikelola, dan disajikan oleh pihak ketiga (misalnya, Google pada aplikasi Google Health).

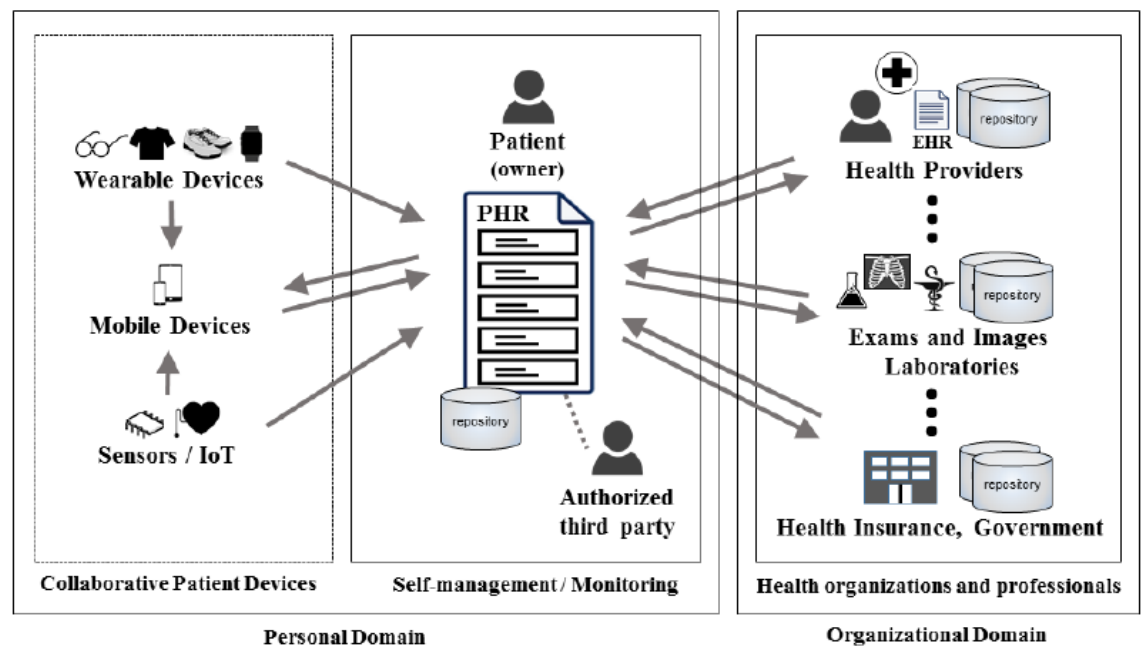

Gambar 1. Ilustrasi arus informasi antara dalam sistem E-PHR (Quaini et al., 2018)

\section{Cakupan Perekaman Informasi}

Dalam model-model yang disebutkan di atas, dapat dilihat terdapat variasi dalam pendekatan metode perekaman informasi termasuk dalam memilih jenis informasi yang direkam dalam sistem E-PHR. Dalam sistem yang diterapkan di Denmark, sistem E-PHR menyimpan seluruh informasi dalam interaksi pasien dengan penyedia layanan kesehatan (Kierkegaard, 2013). Pendekatan yang sama digunakan di Taiwan (Rau et al., 2010) walaupun dalam sistem E-PHR Taiwan data tersebut tidak selalu disimpan dalam repositori terpusat. Sementara itu, sistem HealthConnect di Australia menyimpan data kesehatan pasien secara episodic dengan satu kunjungan disimpan sebagai satu entry dalam sistem (Kolachalam, 2006).

Variasi juga ditemukan dalam jenis dan bentuk informasi kesehatan pribadi yang dapat diakses individual pasien. Pada sistem Denmark, pasien dapat mengakses kelengkapan informasi kesehatan pribadinya secara leluasa melalui situs web terbuka yang dapat diakses di mana saja dan kapan saja (Kierkegaard, 2013). Pada sistem Taiwan, pasien dapat meminta informasi kesehatan pribadinya secara lengkap dalam bentuk piranti lunak dari penyedia layanan kesehatan manapun yang bekerja sama dengan 
sistem E-PHR (Jian et al., 2011). Sementara itu, pasien di Australia hanya dapat mengakses informasi kesehatannya melalui penyedia layanan kesehatan yang dikunjungi, umumnya melalui dokter keluarga (Kolachalam, 2006). Variasi pendekatan tersebut adalah representasi dari variasi dalam sepktrum akademis pengembangan sistem E-PHR.

Di sisi lain, (Tang et al., 2006) menyatakan bahwa data yang terekam dalam sistem eHR tidak serta-merta sama dengan data yang disajikan pada pasien dalam sistem E-PHR. Harus diingat bahwa eHR merujuk pada sistem penyimpanan informasi dalam sistem layanan kesehatan yang relevan bagi penyedia layanan kesehatan sementara PHR merujuk pada akses pasien terhadap data-data tersebut (ISO, 2012). Akan tetapi, (Tang et al., 2006) juga menyatakan bahwa E-PHR diharapkan dapat menyajikan sebanyakbanyaknya informasi kesehatan yang relevan kepada pasien dengan harapan data yang lebih komprehensif yang disajikan kepada pasien akan lebih bermanfaat bagi pasien dalam pengelolaan kesehatan pribadinya.

eHR yang informasinya di-input oleh penyedia layanan kesehatan sudah seharusnya komprehensif meliputi berbagai data kesehatan yang dilayani pada penyedia layanan kesehatan terkait. Pengembangan sistem eHR dibandingkan sistem electronic medical record (EMR) atau rekam medis elektronik adalah sifatnya yang multidisiplin dan melibatkan informasi dari berbagai penyedia layanan kesehatan yang melayani individual pasien (Häyrinen, Saranto and Nykänen, 2008). Informasi dari sistem eHR ini kemudian disadur untuk disajikan pada pasien dalam sistem E-PHR. Pada sistem E-PHR yang terintegrasi dengan sumber data lain, seperti gawai kesehatan, sistem input informasi mandiri oleh pasien, dan lain-lain, maka informasi-informasi ini juga dapat diintegrasikan dalam sistem E-PHR untuk disajikan dan dikelola secara mandiri oleh pasien (Quaini et al., 2018). 
Tabel 2. Rangkuman jenis informasi yang tersedia dalam E-PHR menurut beberapa hasil penelitian yang sudah dilakukan di beberapa negara

\begin{tabular}{|c|c|c|c|}
\hline Jenis Informasi & $\begin{array}{l}\text { Tang dkk. } \\
(2006)\end{array}$ & $\begin{array}{l}\text { Bouayad dkk. } \\
(2017)\end{array}$ & $\begin{array}{l}\text { Roehrs dkk. } \\
\text { (2017) }\end{array}$ \\
\hline Identitas dan Demografi & $\mathrm{X}$ & $\mathrm{X}$ & $\mathrm{X}$ \\
\hline \multicolumn{4}{|l|}{ Data Kunjungan } \\
\hline Daftar keluhan & $\mathrm{X}$ & - & - \\
\hline Diagnosis & $\mathrm{X}$ & $\mathrm{X}$ & $\mathrm{X}$ \\
\hline Pengobatan & $\mathrm{X}$ & $\mathrm{X}$ & $\mathrm{X}$ \\
\hline Tindakan/operasi & $\mathrm{X}$ & - & - \\
\hline $\begin{array}{l}\text { Pemeriksaan } \\
\text { Penunjang }\end{array}$ & $\mathrm{X}$ & $\mathrm{X}$ & $\mathrm{X}$ \\
\hline
\end{tabular}

Riwayat Kesehatan

$\begin{array}{lccc}\text { Riwayat alergi } & \text { X } & - & \text { X } \\ \text { Riwayat imunisasi } & \text { X } & - & \text { X } \\ \text { Riwayat keluarga } & \text { X } & - & \text { X } \\ \text { Asuransi } & - & - & \text { X } \\ \text { Gaya hidup } & \text { X } & \text { X } & \text { X } \\ \text { Genetik } & - & - & \text { X }\end{array}$

Monitoring Pribadi

$\begin{array}{llll}\text { Gula darah sewaktu } & \mathrm{X} & - & \mathrm{X} \\ \text { Tekanan darah } & \mathrm{X} & - & \mathrm{X}\end{array}$

Layanan Kesehatan

$\begin{array}{llll}\text { Pendaftaran online } & - & \text { X } & \text { X } \\ \text { Riwayat fasyankes } & - & \text { X } & \text { X } \\ \text { Komunikasi } & - & \text { X } & -\end{array}$

Tang dkk (2005) juga menjabarkan beberapa jenis informasi yang diharapkan akan dapat disajikan pada pasien. Informasi ini mencakup daftar keluhan, riwayat penyakit, riwayat tindakan, riwayat alergi, riwayat penyakit keluarga, riwayat pengobatan, imunisasi, dan hasil pemeriksaan penunjang. Roehrs dkk (2017) sebagian besar sependapat dengan 
pernyataan di atas tetapi menambahkan potensi penambahan informasi riwayat fasilitas layanan kesehatan yang dikunjungi. Rangkuman jenis informasi yang diharapkan tersedia dalam sistem E-PHR dari beberapa sumber dapat dilihat dalam tabel di atas.

Dari tabel di atas dapat dilihat bahwa sebagian besar sumber sepakat mengenai penyajian beberapa tipe informasi. Informasi riwayat kunjungan ke fasilitas layanan kesehatan yang diharapkan muncul meliputi diagnosis, pengobatan, dan hasil pemeriksaan penunjang. Riwayat kesehatan pribadi yang diharapkan muncul meliputi riwayat alergi, imunisasi, riwayat penyakit keluarga, dan gaya hidup. Riwayat monitoring pribadi, seperti gula darah sewaktu dan tekanan darah juga dianggap penting untuk disajikan untuk membantu pengelolaan penyakit kronis. Sementara itu, sistem E-PHR juga diharapkan memfasilitasi layanan-layanan seperti pendaftaran online di fasilitas layanan kesehatan serta daftar layanan-layanan kesehatan langganan pasien.

\section{Evaluasi dan Indikator Keberhasilan Sistem E-PHR}

Manfaat utama dari sistem E-PHR adalah peningkatan efisiensi sistem layanan kesehatan. Dalam beberapa kajian, peningkatan efisiensi ini dikuantifikasi dalam bentuk uang di mana setiap percepatan proses dalam layanan kesehatan, misalnya percepatan proses rujukan, divaluasi dalam bentuk uang yang kemudian diakumulasikan (Cannaby et al., 2004). Akan tetapi, evaluasi dalam hal ini sulit dilakukan akibat memerlukan pemodelan matematika yang rumit.

Pendekatan lain dalam mengevaluasi keberhasilan sistem E-PHR adalah dengan melihat penggunaan E-PHR oleh tenaga medis dan pasien yang menjadi sasaran sistem E_PHR tersebut. Terkait dengan efisiensi, penggunaan dapat menjadi pendekatan yang baik akibat adanya asumsi mendasar dalam memperkirakan efek E-PHR terhadap efisiensi yaitu kemampuan E-PHR dalam menggantikan sistem informasi tradisional berbasis kertas.

Penggunaan E-PHR sendiri dapat dinilai melalui beberapa pengukuran. Pengukuran pertama adalah dengan melihat jumlah anggota yang terdaftar dalam sistem E-PHR tersebut. Evaluasi ini dlakukan oleh public dan media Australia pada bulan dan tahun segera setelah dimulainya 
program My Health Record di Australia. Dalam salah satu liputan pada tujuh bulan pasca diluncurkannya My Health Record, salah satu media di Australia melaporkan bahwa pendaftaran akun My Health Record hanya mencapai 50 ribu akun, jauh di bawah target 500 ribu akun dalam 12 bulan (Hilvert, 2013).

Akan tetapi, pendaftaran akun sendiri tidak melulu dapat dijadikan indikator bermakna terhadap penggunaan suatu sistem E-PHR. Hal ini dapat dilihat dari studi kasus di Australia di mana setelah lambatnya pertumbuhan akun terdaftar, pemerintah mewajibkan kepesertaan dalam sistem $M y$ Health Record dengan mengubah kebijakan kepsertaan dari opt-in menjadi opt-out. Perubahan kebijakan seperti ini akan menambah jumlah pengguna terdaftar tanpa meningkatkan penggunaan bermakna oleh masyarakat dan tenaga medis.

Oleh karena itu, indikator penggunaan alternatif adalah dengan melihat traffic atau arus informasi yang beredar dalam suatu sistem E-PHR. Arus informasi ini dapat dinilai dari jumlah dokumen yang diunggah dan diunduh dari sistem E-PHR. Secara tidak langsung, penggunaan bermakna juga dapat dinilai dari seberapa banyak layanan elektronik dalam sistem EPHR mampu menggantikan bentuk layanan konvensional.

Sebagai contoh, dalam studi kasusnya terhadap sistem e-Kesehatan Denmark, Kierkegaard (2013) mencantumkan peningkatan jumlah komunikasi dalam sistem E-PHR sebagai salah satu indikator keberhasilan. Jumlah pesan dalam sistem pengiriman pesan per bulan dalam sistem EPHR Denmark meningkat secara konsisten sejak diluncurkan pada 1994 dan mencapai plateau pada 2010 dan seterusnya. Indikator keberhasilan lain yang dicantumkan adalah tingginya penggunaan telemedicine atau konsultasi kesehatan dengan email yang disediakan dalam sistem E-PHR (Kierkegaard, 2013). Sementara itu, laman web My Health Record Australia juga menyediakan laporan yang diperbaharui secara berkala mengenai jumlah data yang diunggah dalam sistem, meliputi dokumen klinis dan dokumen pengobatan yang diunggah tenaga medis, serta dokumen yang diunggah pengguna (MyHR, 2019a). 


\section{Perbandingan Model E-PHR}

Terdapat beberapa percontohan sistem E-PHR yang dibangun di beberapa negara, sebagian sudah memulai inisiatif ini sejak dekade 2000an. Denmark adalah salah satu negara yang sudah lama mengembangkan sistem E-PHR dalam sistem kesehatan nasionalnya. Sistem E-PHR di Denmark dikarakterisasi dengan integrasi repositori informasi kesehatan pasien dari pusat-pusat layanan kesehatan, termasuk dokter keluarga, spesialis, dan rumah sakit. Dalam sistem E-PHR Denmark, masukan informasi masih dilakukan dari penyedia layanan kesehatan primer. Inisiasi masukan informasi bisa berawal dari dokter keluarga ataupun dari instalasi gawat darurat. Segala bentuk komunikasi antar penyedia layanan kesehatan berbeda (misalnya antar dokter keluarga dan spesialis, dokter keluarga dan rumah sakit, dll) dilakukan secara digital. Dokter keluarga juga menerima notifikasi digital jika ada kliennya yang masuk instalasi gawat darurat (Kierkegaard, 2013). Aspek PHR dari sistem E-PHR Denmark adalah pemberdayaan pasien untuk mengakses informasi riwayat kesehatannya melalui situs web Sundhed.dk. Melalui situs web ini, pengguna layanan kesehatan di Denmark dapat mengakses informasi riwayat kesehatannya, memesan jadwal pemeriksaan, memantau ketaatan minum obat, dan lainlain. Akan tetapi, pengguna non-tenaga medis tidak dapat mengubah isi, baik seluruhnya atau sebagian, dari isi informasi kesehatan dalam sistem tersebut (Sundhed.dk, 2019). 


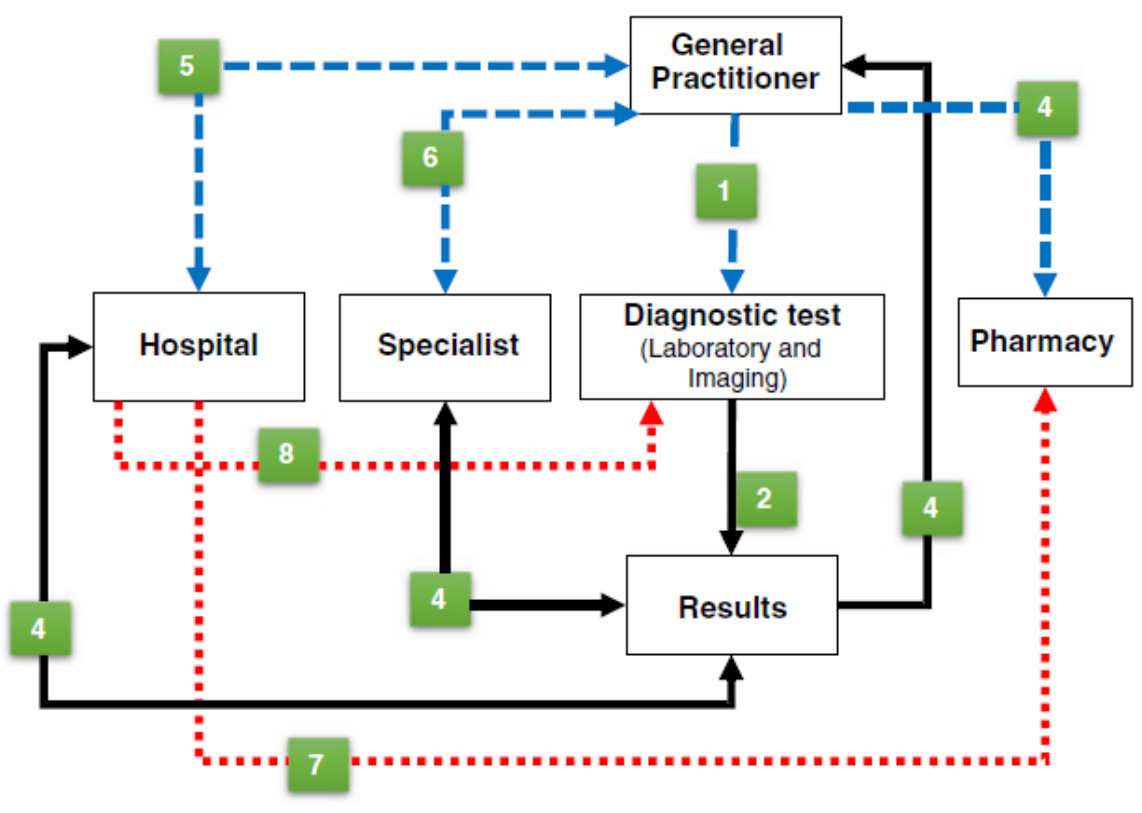

Gambar 2. Arus informasi dalam sistem E-PHR Denmark. 1 dan 8) permintaan pemeriksaan penunjang, 2) Pemeriksaan penunjang, 3 dan 7) pesanan resep ke apotek, 4) pengambilan hasil pemeriksaan penunjang, 5 dan 6) pembuatan rujukan atau resume pulang

Negara lain yang telah menginisiasi program E-PHR adalah Australia melalui inisiatif HealthConnect. Inisiatif ini serupa dengan program E-PHR Denmark yaitu berupa repositori informasi rekam medis elektronik terpadu. Sama dengan E-PHR Denmark, masukan data dalam HealthConnect diinisiasi oleh penyedia layanan kesehatan baik dokter keluarga, spesialis, ataupun rumah sakit. Rekam medis direkam secara episodik, yaitu masingmasing kunjungan dimasukkan sebagai satu entry dalam sistem (Kolachalam, 2006).

Perbedaan terletak pada pemberdayaan pasien dalam menyimpan dan mengakses informasi. Dalam HealthConnect, semua proses yang melibatkan informasi kesehatan pasien harus dilakukan dengan izin dari pasien. Proses yang dimaksud meliputi masukan data rekam medis ke repositori bersama, pengiriman data rekam medis ke layanan kesehatan lain, hingga akses penyedia layanan kesehatan terhadap data rekam medis tersebut (Kolachalam, 2006). Perkembangan terbaru dari HealthConnect adalah diluncurkannya layanan My Health Record (MyHR), sebuah platform 
E-PHR dengan model serupa dengan sundhed.dk di Denmark. Prinsip kuasa pasien tetap diterapkan dengan adanya fitur yang memampukan pasien mengunggah informasi kesehatan sendiri yang dianggap relevan serta menghapus informasi-informasi yang diunggah oleh penyedia layanan kesehatan (MyHR, 2019b)

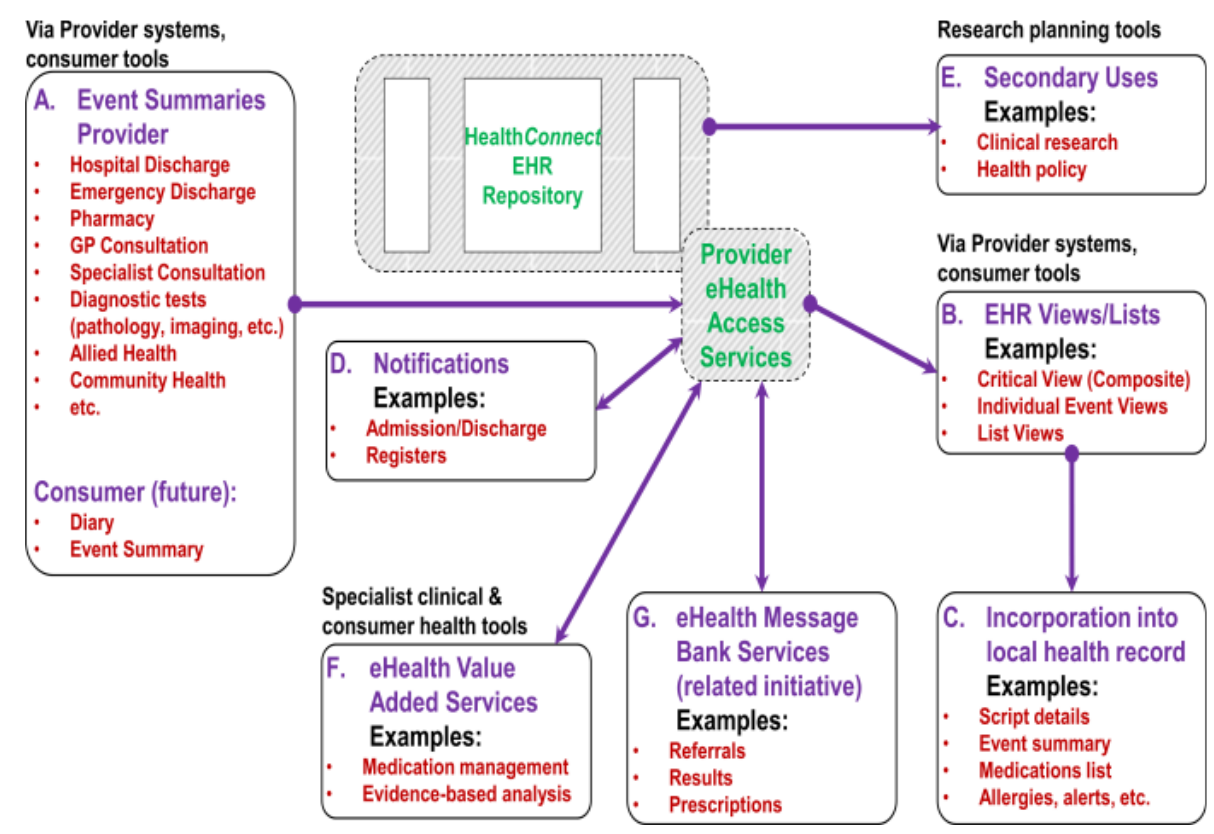

Gambar 3. Alur arus informasi dalam HealthConnect Australia (Kolachalam, 2006).

Inisiasi E-PHR juga dilakukan Taiwan. Dalam mengembangkan sistemnya, Taiwan berusaha mengintegrasikan sistem-sistem eHR yang sudah banyak digunakan di rumah sakit. Heterogenitas sistem-sistem eHR menjadi kendala komunikasi informasi kesehatan yang efektif dan informasi kesehatan. Perbedaan dari sistem Australia dan Denmark adalah tidak adanya repositori atau bank data terpusat untuk informasi kesehatan. Kecuali atas izin pasien, data rekam medis disimpan dalam reposiotori lokal di rumah sakit masing-masing. Penyeragaman sistem informasi dan teknologi konversi data dikemabangkan untuk menunjang komunikasi kesehatan antar fasilitas layanan kesehatan yang tidak tergantung pada repositori terpusat (Rau et al., 2010). Selain itu, sama seperti di Australia, pasien dapat mengakses informasi kesehatan pribadinya hanya melalui 
penyedia layanan kesehatan yang merupakan anggota sistem E-PHR tersebut (Jian et al., 2011).

\section{Fasilitator dan Kendala}

Fasilitator dan kendala dalam pengembangan dan pelaksanaan sistem E-PHR dapat dikategorikan ke dalam dua aspek: aspek teknis dan aspek personel atau pengguna. Aspek teknis meliputi kesiapan infrastruktur, sarana, dan prasaran teknologi informasi yang digunakan dalam sistem E-PHR. Sementara aspek pengguna meliputi kesiapan dan kesanggupan tenaga kesehatan serta pasien untuk menggunakan sistem EPHR yang akan dikembangkan.

\section{Fasilitator dan Kendala Teknis}

Asumsi dasar pengembangan sistem E-PHR adalah ketersediaan infrastruktur teknologi informasi untuk menunjang penggunaan sistem EPHR di lapangan. (Steele, Min and Lo, 2012) menjabarkan kebutuhan infrastruktur teknologi informasi dasar sesuai dengan jenis PHR yang dikembangkan. Untuk E-PHR terintegrasi, yang mengintegrasi informasi dari sistem eHR beberapa penyedia layanan kesehatan pada wilayah tertentu, memerlukan infrastruktur dasar yang meliputi piranti keras, piranti lunak, dan sambungan internet yang stabil. Piranti keras diperlukan terutama untuk penyimpanan data dan dapat diaktualisasikan sebagai server fisik berbasis web atau aplikasi ataupun dengan memanfaatkan teknologi cloud computing. Piranti keras juga diperlukan untuk mengakses informasi dalam sistem E-PHR tersebut, oleh karena itu pengembangan dan adopsi sistem E-PHR secara luas memerlukan cakupan penggunaan komputer, laptop, ataupun smartphone yang cukup luas pada populasi target.

Sementara itu, piranti lunak yang digunakan menjadi dasar pengelolaan dan akses data dalam sistem E-PHR. Pada sistem E-PHR yang diakses melalui web, maka piranti lunak yang diperlukan cukup browser web sederhana. Sementara itu, sistem E-PHR yang dikembangkan dengan aplikasi terdedikasi memerlukan penyebarluasan dan adopsi aplikasi tersebut oleh populasi target. Setelah pengembangan sistem, syarat terpenting penggunaan sistem E-PHR tersebut oleh pasien dan tenaga medis adalah ketersediaan sambungan internet yang stabil untuk menghubungkan 
piranti keras pengguna dan server tempat tersimpannya informasi kesehatan (Steele, Min and Lo, 2012).

Dalam pengembangan piranti lunak di atas, terdapat beberapa kendala tersendiri. Tidak jarang pengembangan sistem eHR dan EMR berlangsung sporadic pada masing-masing fasilitas layanan kesehatan. Selain itu, alat-alat yang digunakan dalam sistem informasi masing-masing fasilitas layanan kesehatan tidak selalu menggunakan piranti lunak dengan program yang sama. Variasi bahasa pemrograman antar piranti keras dan sistem-sistem eHR yang akan diintegrasikan ini menjadikan interoperabilitas suatu kendala teknis yang besar (Quaini et al., 2018).

Masalah interoperabilitas didasari kendala teknologi dan kendala budaya kerja. Adopsi teknologi informasi kesehatan secara sporadis dan tanpa perencanaan jangka panjang untuk integrasi membatasi kemampuan integrasi di masa depan. Oleh karena itu, pengembangan sistem E-PHR harus dilakukan secara bertahap, diawali dengan standarisasi sistem informasi eHR pada berbagai fasiltias layanan kesehatan yang akan diintegrasikan. Secara budaya, masalah interoperabilitas didasari adanya kompetisi antara produsen-produsen sistem eHR yang saling berlomba mengembangkan dan mempromosikan sistem eHR yang dikemabangkan sendiri. Kolaborasi yang erat antar berbagai pemangku kepentingan, mulai pemgembang sistem, pengembang program, tenaga kesehatan, dan masyarakat umum, diperlukan untuk mengembangkan sistem E-PHR yang dapat digunakan secara integratif dan komprehensif (Reisman, 2017).

Berdasarkan uraian di atas, beberapa sistem kesehatan yang sudah memiliki baseline yang baik dalam aspek teknologi seperti dijabarkan di atas akan memiliki kemudahan dalam mengembangkan sistem E-PHR. Salah satu contohnya adalah Denmark yang sudah memiliki sistem informasi kependudukan terpadu sebelum mengembangkan sistem E-PHR. Sistem informasi kependudukan ini dijadikan dasar pengembangan E-PHR yang universal dan meliputi semua penduduk. Contoh lain adalah Singapura yang, pada awal pengembangan E-PHR, sudah memiliki cakupan penggunaan teknologi yang tinggi pada sistem kesehatannya. Dengan cakupan penggunaan piranti keras yang luas, maka pengembangan E-PHR dapat dimulai dari pengembangan sistem informasi yang interoperable (NEHTA, 2016). 
Tabel 3. Kendala-kendala Pengembangan dan Adopsi Sistem E-PHR

\begin{tabular}{lll}
\hline \multicolumn{1}{c}{ Kendala Teknis } & Kendala Tenaga Medis & \multicolumn{1}{c}{ Kendala Pasien } \\
- Cakupan komputerisasi & - Kekhawatiran tidak & • Demografi yang lambat \\
pada fasiltias layanan & tepatnya informasi & mengadopsi teknologi: \\
kesehatan & dalam sistem E-PHR & ○ Usia tua \\
- Variasi piranti lunak & - Kehawatiran & ○ Sosioekonomi \\
antara fasilitas-fasiltias & penambahan beban & rendah \\
layanan kesehatan & kerja tanpa & ○ Pendidikan rendah \\
- Kurangnya & penambahan insentif & - Iliterasi kesehatan \\
interoperabilitas antar & finansial & - Kekhawatiran akan \\
piranti lunak yang & Belum jelasnya & kebocoran informasi \\
bervariasi & tanggung jawab hukum & kesehatan pribadi dalam \\
- Perlunya cakupan luas & tenaga medis terhadap & sistem E-PHR \\
sambungan internet & isi informasi dalam & \\
pada pusat-puusat & sistem E-PHR & \\
layanan kesehatan & &
\end{tabular}

\section{Fasilitator dan Kendala Pengguna}

Pengguna E-PHR meliputi tenaga medis dan pasien, dan masingmasing pemangku kepentingan ini memiliki sudut pandang yang berbeda mengenai fasilitator dan kendala dalam penggunaan E-PHR. Sistem E-PHR yang telah dikembangkan tidak selalu serta merta digunakan secara luas oleh pasien dan tenaga kesehatan. Temuan ini ditemukan di Inggris Raya. Pemerintah Inggris, melalui sistem kesehatan nasional mereka, mengembangkan sistem E-PHR yang akhirnya dibatalkan pada 2011 akibat kesulitan penggunaan. Masalah di Inggris Raya bermula dari implementasi sistem E-PHR yang kurang persiapan, tidak diawali dengan usaha standarisasi program untuk meningkatkan interoperabilitas, mengurangi manfaat bagi tenaga kesehatan dan pasien sehingga mengurangi minat penggunaan (NEHTA, 2016).

Faktor-faktor yang menghambat penggunaan E-PHR pada tenaga medis meliputi ketidakpercayaan terhadap ketepatan informasi dalam EPHR, kekhawatiran mengenai tidak jelasnya tanggung jawab hukum terhadap isi E-PHR, serta kekhawatiran terhadap peningkatan beban kerja tanpa diiringi peningkatan pendapatan dari penggunaan E-PHR (Vance et al., 2015). Peningkatan beban kerja dapat dikaitkan pada kenyataan bahwa sebagian besar fasilitas layanan kesehatan yang mengadopsi sistem E-PHR 
tidak menghilangkan sistem pencatatan rekam medis berbasis kertas. Akibatnya tenaga medis sering kali harus melakukan kerja ganda, mencatat informasi kesehatan dalam sistem eHR dan dalam media kertas (Quaini et al., 2018).

Sementara itu, dari sisi pasien hambatan penggunaan E-PHR dipengaruhi kelompok demografis dan sikap terhadap pengembangan teknologi E-PHR itu sendiri. Berkaitan dengan demografis, pasien berusia tua, status sosioekonomi rendah, dan pendidikan rendah diidentifikasi sebagai kelompok yang lebih lambat menggunakan E-PHR. Selain itu, ketidakmampuan memanfaatkan E-PHR yang ditandai dengan iliterasi kesehatan juga menghambat penggunaan E-PHR (Showell, 2017). Sementara itu, sikap yang negatif terhadap E-PHR dipengaruhi kekhawatiran mengenai keamanan data dalam sistem E-PHR. Banyak pasien mengkhawatirkan kemungkinan kebocoran data informasi kesehatan pribadi seharusnya bersifat rahasia. Pasien juga mengkhawatirkan pihak mana saja yang memiliki akses terhadap informasi kesehatan mereka Pasien juga mengkhawatirkan pihak mana saja yang memiliki akses terhadap informasi kesehatan mereka (Vance et al., 2015).

Seperti disebut di atas, Inggris Raya gagal menerapkan sistem E-PHR yang dibatalkan pada 2011 akibat kegagalan memitigasi kendala-kendala adopsi E-PHR. Sementara itu, negara yang berhasil menerapkan E-PHR umumnya melakukan langkah-langkah mitigasi. Implementasi E-PHR di Singapura dilakukan secara bertahap selama 10 tahun dengan evaluasievaluasi dilakukan secara berkala diiringi pelatihan teknologi informasi secara rutin (NEHTA, 2016). Sementara itu, penerapan sistem di Denmark menginkorporasi insentif finansial bagi tenaga medis untuk mengkompensasi peningkatan beban kerja terkait E-PHR (Kierkegaard, 2013).

\section{Analisa Biaya}

Analisa biaya E-PHR masih belum bisa dilakukan secara jelas. Variasi yang ada dalam pemodelan dan arsitektur sistem informasi E-PHR menyebabkan estimasi biaya dan nilai manfaat E-PHR secara finansial sulit dilakukan (Gunter and Terry, 2005). Untuk analisa ini, estimasi biaya dan manfaat dilakukan dengan pendekatan model berbasis penyedia layanan 
kesehatan. Dalam model ini, data yang disajikan pada pasien diperoleh dari data yang disediakan sistem informasi penyedia layanan kesehatan. Alternatif sistem ini adalah sistem E-PHR berbasis asuransi, di mana data kesehatan pasien disimpan dan diolah oleh penyedia-penyedia layanan asuransi, dan sistem E-PHR berbasis pihak ketiga, di mana data kesehatan pasien disimpan dan diolah oleh penyedia jasa sistem informatika seperti Google atau Microsoft (Shah et al., 2008). Pendekatan estimasi biaya berdasarkan sistem E-PHR berbasis penyedia layanan kesehatan melihat dari keadaan di Indonesia, dan Badung khususnya, di mana sistem layanan kesehatan umum yang direpresentasikan puskesmas dan rumah sakit daerah berperan besar dalam penyediaan layanan kesehatan pada masyarakat.

Estimasi biaya yang dilakukan di Amerika Serikat mengestimasi biaya yang diperlukan untuk memulai pengembangan sistem E-PHR mencapai USD 2,8 juta. Komponen terbesar dari estimasi biaya ini adalah pengadaan pusat data atau server sebagai piranti keras penyimpanan dan pengolah data dan program dalam sistem E-PHR. Dalam estimasi tersebut, biaya yang diperlukan untuk menyiapkan pusat data mencapai USD 1,7 juta, atau lebih dari setengah dari total estimasi biaya yang diperlukan (Shah et al., 2008). Selain itu terdapat biaya tahunan untuk penyelenggaraan sistem E-PHR ini yang diperkirakan mencapai USD 1,2 juta setiap tahunnya (Kaelber and Pan, 2008).

Akan tetapi, harus disadari bahwa dengan berkembangnya teknologi sejak estimasi biaya tersebut diterbitkan pada 2008, biaya yang diperlukan untuk mengembangkan sistem E-PHR juga berkurang. Salah satu kemajuan teknologi yang dapat menghemat biaya adalah teknologi cloud computing yang diperkirakan dapat meningkatkan interoperabilitas sistem dengan biaya yang lebih murah dibandingkan menyiapkan piranti keras untuk pusat data (Ahmadi and Aslani, 2018). Akan tetapi, belum terdapat studi yang menyediakan angka estimasi biaya untuk pengembangan sistem E-PHR berbasis cloud computing ini.

Sementara itu, manfaat yang diperoleh dari penerapan sistem E-PHR terutama diperoleh dari efisiensi pelayanan kesehatan. Peningkatan efisiensi terkait E-PHR ini terutama terlihat dari efisiensi waktu yang diperoleh dalam pemberian pelayanan seperti perujukan dan pemeriksaan. 
Diasumsikan dengan sistem E-PHR beberapa layanan kesehatan tidak memerlukan lagi pertemuan tatap muka antara penyedia layanan kesehatan dan pengguna layanan kesehatan, sehingga menghemat waktu dan biaya perjalanan, serta waktu yang diperlukan untuk pelayanan itu sendiri. Peningkatan efisiensi dengan cara ini diperkirakan menghemat USD 14 miliar per tahun untuk cakupan layanan yang mencapai $80 \%$ penduduk Amerika Serikat (Kaelber and Pan, 2008).

Evaluasi pelaksanaan program E-PHR di Denmark sendiri menghasilkan data serupa. Dari segi perujukan secara elektronik saja, pengehmatan sudah dapat dicapai. Pada situasi di mana rujukan sudah seluruhnya dilakukan secara elektronik, maka dapat dicapai penghematan sebesar EUR 3,5 juta (Cannaby et al., 2004).

\section{Pengembangan E-PHR untuk Promosi Kesehatan}

\section{Fitur-fitur Dalam Aplikasi e-Kesehatan untuk Promosi Kesehatan}

Sistem E-PHR berbasis aplikasi bersinggungan dengan konsep ekesehatan. Konsep ini merujuk pada penggunaan teknologi informasi elektronik (e-kesehatan) sebagai sarana yang dapat digunakan dalam pengembangan program kesehatan masyarakat. Konsep e-kesehatan dalam promosi kesehatan bersifat luas dan melingkupi semua bentuk komunikasi elektronik. Laporan WHO untuk wilayan Eropa menemukan bahwa 81\% dari negara anggota WHO di Eropa menggunakan media sosial dalam kampanye promosi kesehatan nasional (WHO, 2016).

Dari tinjauan pustaka, sebagian besar program-program e-kesehatan untuk promosi kesehatan bertujuan promosi program diet dan olahraga atau gaya hidup sehat secara umum. Aplikasi promosi kesehatan ini umumnya memiliki fitur penyampaian informasi kesehatan, sebagai 'diari' kesehatan di mana pengguna bisa mengukuti capaian perubahan gaya hidup yang diharapkan, serta memberi timbal balik mengenai status kesehatan pengguna. Untuk tujuan promosi diet dan gaya hidup sehat, penggunaan aplikasi dengan fitur-fitur ini ditemukan efektif dalam memperbaiki pola makan pengguna serta menghasilkan luaran penurunan berat badan yang signifikan. Pengguna juga memperoleh peningkatan pengetahuan tentang nutrisi seimbang serta faktor risiko penyakit kardiovaskuler. Bisa dikatakan 
bahwa promosi kesehatan dengan pendekatan aplikasi e-kesehatan ini efektif dalam mencapai tujuannya (Lee et al., 2018).

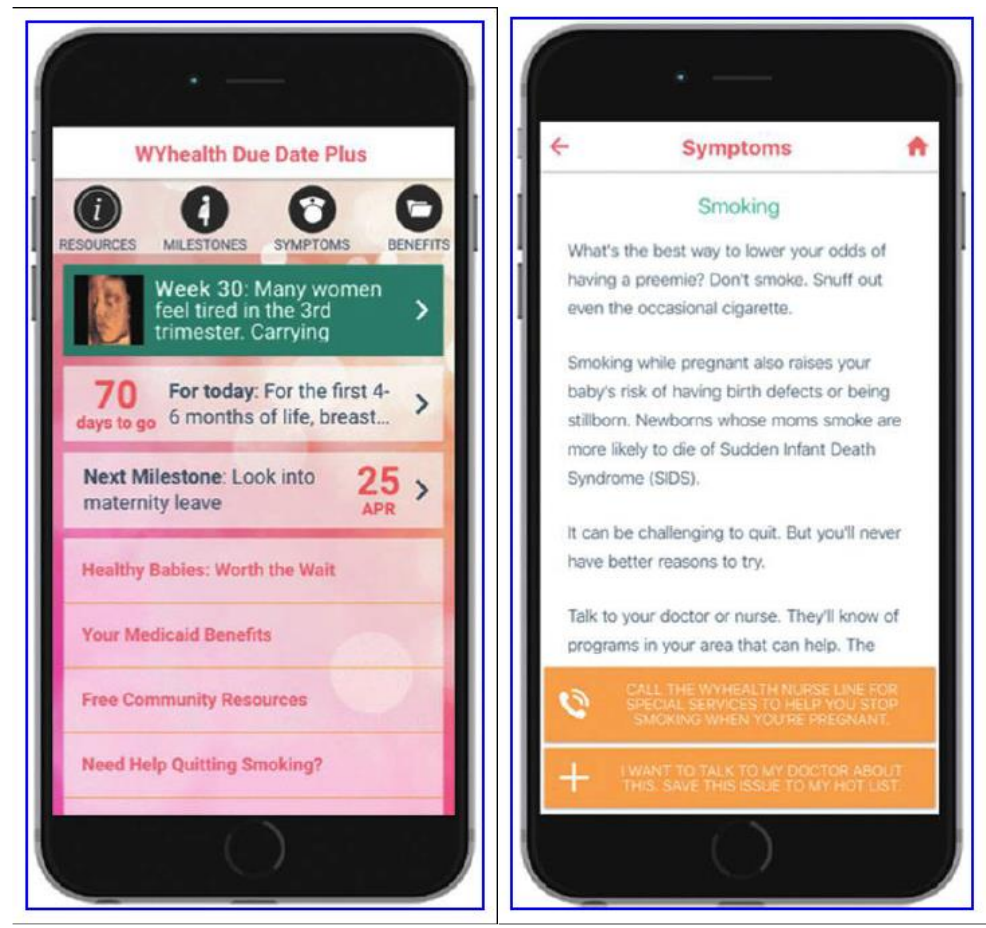

Gambar 4. Tampilan aplikasi WYhealth Due Date Plus di Wyoming, Amerika Serikat (Bush et al., 2017).

Promosi kesehatan yang dilakukan dengan kerangka e-kesehatan tidak terbatas pada program diet dan penurunan berat badan. Beberapa aplikasi e-kesehatan dikembangkan dengan tujuan promosi kesehatan maternal dan juga imunisasi. Aplikasi kesehatan maternal dapat memiliki fitur penyampaian informasi mengenai informasi kesehatan, kejadiankejadian penting yang dapat ditemukan dalam perjalanan kehamilan, faktor-faktor risiko untuk membantu ibu hamil mengidentifikasi diri sendiri, serta fitur interaktif untuk pelacakan perubahan berat badan selama kehamilan. Aplikasi juga memiliki fitur pengingat jadwal pemeriksaan kehamilan untuk ibu hamil. Studi percontohan aplikasi kesehatan maternal di Wyoming, Amerika Serikat menunjukkan interaksi pengguna yang tinggi dan menghasilkan luaran penurunan risiko berat badan lahir rendah (Bush et al., 2017). Sementara itu aplikasi imunisasi dapat memiliki fitur komunikasi satu arah seperti informasi terkait berbagai jenis vaksin dan 
pengingat jadwal imunisasi. Aplikasi serupa di Amerika Serikat ditemukan mampu menarik minat pengguna dan menghasilkan interaksi pengguna yang tinggi, akan tetapi belum ada hasil konklusif mengenai efektivitasnya dalam meningkatkan capaian imunisasi (Bednarczyk et al., 2017).

Penelitian pada pelaku pasar menemukan bahwa terdapat beberapa fitur yang diinginkan oleh pengguna aplikasi promosi kesehatan. Fitur yang diingkan ini berbeda untuk jenis aplikasi e-kesehatan dengan tujuan yang berbeda pula. Misalnya, populasi dewasa dengan gaya hidup sedentary, target pasar untuk aplikasi diet dan olah raga, menginginkan aplikasi ekesehatan yang memiliki fitur pengukuran capaian olah raga (misalnya penghitungan langkah kaki atau jarak lari yang ditempuh), pelacakan capaian penurunan berat badan, aplikasi musik yang terintegrasi, serta sistem antar muka (interface) yang mudah digunakan (Rabin and Bock, 2011). Sementara itu, untuk aplikasi kesehatan maternal, ibu hamil mengharapkan aplikasi yang memiliki fitur-fitur seperti pelacakan perkembangan kehamilan, penyimpanan data seperti foto dan video untuk pelacakan perkembangan kehamilan, serta notifikasi dan pengingat untuk pemeriksaan (Hughson et al., 2018).

\section{Peran Pemerintah dalam Pengembangan e-Kesehatan untuk Promosi Kesehatan}

Berbeda dengan perkembangan eMR, eHR, dan E-PHR, pemerintah tidak berperan besar dalam pengembangan aplikasi e-kesehatan untuk promosi kesehatan. Denmark dan Australia, dua negara dengan sistem EPHR berbasis internet yang ekstensif, tidak memiliki program ataupun aplikasi e-kesehatan untuk promosi kesehatan. Program Sundhed.dk dari Denmark dan My Health Record dari Australia hanya memiliki fitur perekaman dan komunikasi informasi kesehatan pribadi dan tidak memiliki fitur promosi kesehatan seperti yang dijabarkan di atas.

Contoh keterlibatan pemerintah dalam e-kesehatan adalah dengan melakukan kurasi dan review terhadap aplikasi e-kesehatan yang dikembangkan oleh swasta. Sebagai contoh, pemerintah Negara Bagian Victoria di Australia merilis daftar aplikasi e-kesehatan yang telah direview dan dipromosikan untuk digunakan oleh publik. Aplikasi e-kesehatan yang dipromosikan meliputi aplikasi untuk penurunan berat badan, aplikasi 
untuk olah raga, aplikasi kesehatan mental, dan aplikasi untuk pecandu rokok dan alcohol (VicHealth, 2019).

\section{Integrasi Promosi Kesehatan Berbasis e-Kesehatan dalam Sistem E- PHR}

Kendala dalam integrasi fitur e-kesehatan untuk promosi kesehatan dalam sistem E-PHR adalah beragamnya tujuan promosi kesehatan yang dapat dicapai. Masing-masing tujuan promosi kesehatan memiliki kerangka dan fitur-fitur spesifik yang hanya berlaku untuk tujuan tersebut. Seperti disebutkan di atas, fitur yang diharapkan dari aplikasi e-kesehatan maternal berbeda dari fitur yang diharapkan dalam aplikasi diet dan penurunan berat badan. Oleh karena itu, sulit untuk mengintegrasikan berbagai tujuan promosi kesehatan dalam satu aplikasi. Kesulitan ini akan bertambah jika aplikasi tersebut juga diintegrasikan dalam aplikasi E-PHR.

Pendekatan alternatif yang lebih memungkinkan adalah mengembangkan berbagai aplikasi e-kesehatan untuk tujuan-tujuan promosi kesehatan yang spesifik dengan penyimpanan data yang terintegrasi atau dapat diakses oleh sistem E-PHR. Seperti dapat dilihat dalam Gambar 1, smartphone dan alat-alat e-kesehatan merupakan salah satu sumber informasi untuk sistem E-PHR (Quaini et al., 2018).
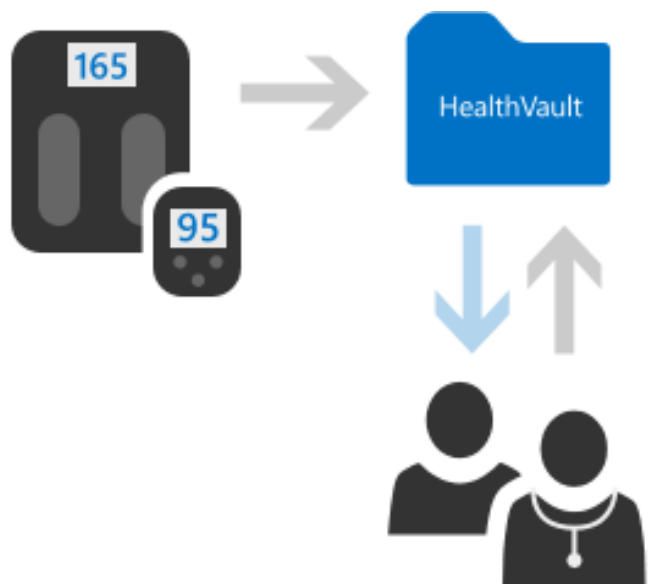

Gambar 5. Ilustrasi arus informasi dalam sistem E-PHR HealthVault dengan aplikasi promosi kesehatan elektronik (e-kesehatan) sebagai salah satu sumber (HealthVault, 2019). 
Contoh dari integrasi E-PHR dan aplikasi e-kesehatan adalah sistem Microsoft HealthVault. HealthVault adalah sistem E-PHR swasta yang dikembangkan oleh perushaan informatika Microsoft. HealthVault sendiri merupakan sistem penyimpanan dan akses data kesehatan pribadi, suatu sistem E-PHR, yang menjadi tulang punggung, dan ditunjang oleh, berbagai aplikasi dan alat kesehatan lain yang menjadi sumber informasi dan data dalam HealthVault itu sendiri. Jaringan e-kesehatan HealthVault meliputi 111 aplikasi meliputi promosi kesehatan nutrisi, penyakit tidak menular, kehamilan, dan kesehatan mental (HealthVault, 2019).

\section{Studi Kasus Implementasi E-PHR di Australia}

\section{Persiapan: Peraturan, Standarisasi, dan Pengadaan Infrastruktur}

Pada 2012, Australia meluncurkan program E-PHR daringnya yang bertajuk My Health Record atau MyHR. Penerapan MyHR, yang diundangundangkan pada tahun 2012, dilakukan hampir satu dekade setelah inisiasi program integrasi teknologi informasi kesehatan Australia, yaitu HealthConnect pada 2004. Sebelum diundangkan, parlemen dan pemerintah Australia lebih dulu mencanangkan strategi nasional untuk implementasi sistem e-kesehatan di negaranya. Salah satu luaran dari HealthConnect adalah disepakatinya kerangka standardisasi dalam sistem informasi kesehatan Australia (Bott, 2004).

Dalam masa persiapan ini juga disiapkan infratruktur informasi kesehatan nasional. Salah satunya adalah penerbitan Healthcare Identifiers Act of 2010 (Undang-undang Identitas Layanan Kesehatan tahun 2010). Undang-undang ini memandatkan pembentukan sistem identifikasi individual dalam sistem informasi kesehatan nasional yang kemudian menjadi dasar pembentukan sistem eHR yang terintegrasi. Selain persiapan infrastruktur kesehatan dari segi peraturan perundang-undangan, dilakukan juga persiapan infrastruktur secara fisik.

Dalam dokumen Strategi e-Kesehatan Nasional tahun 2008 dimandatkan persiapan infrastruktur komputer yaitu pengadaan personal computer dan koneksi internet untuk penyedia layanan kesehatan. Bagi penyedia layanan kesehatan swasta, Strategi Nasional tersebut memandatkan insentif agar pihak swasta juga berinvestasi dalam pengadaan piranti keras tersebut. Strategi Nasional tersebut juga 
memandatkan penguatan layanan koneksi internet pita lebar untuk menjamin koneksi internet yang stabil bagi pengguna dan penyedia layanan kesehatan. Salah satu prinsip pengadaan ini menurut Strategi Nasional tersebut adalah pengadaan secara serentak pada semua daerah Australia, untuk mencegah perlunya perbaikan-perbaikan susulan akibat piranti keras yang diadakan terlebih dahulu kemudian menjadi using saat menunggu pengadaan di tempat lain (AHMC, 2008).

\section{Implementasi: Arsitektur Sistem MyHR}

Setelah ditetapkan berdasarkan Personally Controlled Electronic Health Record Act tahun 2012, sistem ini menerapkan arsitektur E-PHR terhubung. Dalam sistem ini data yang dimasukkan dalam sistem eHR penyedia layanan kesehatan tidak serta merta diikutsertakan ataupun disimpan dalam penyimpanan informasi yang terpusat. Hanya sebagian data dalam eHR yang disimpan dalam pusat penyimpanan data yang terhubung dengan sistem pusat MyHR yang dapat diakses melalui MyHR. Pasien berkuasa penuh dalam menentukan data mana yang dimasukkan dalam penyimpanan data terhubung (repository) ini (Pearce and Bainbridge, 2014).

Kenyataan ini dapat dilihat pada gambar di bawah (Nøhr et al., 2017). Dapat dilihat bahwa penyedia layanan kesehatan masing-masing memiliki pusat piranti keras untuk penyimpanan data. Penyimpanan data yang terdistribusi ini terhubung dengan pusat data MyHR. Penambahan atau perubahan data yang tersimpan pada pusat penyimpanan data yang tersebar tersebut secara otomatis tercatat, walaupun secara fisik data tersebut tidak tersimpan, dalam sistem antamuka (interface) MyHR. 


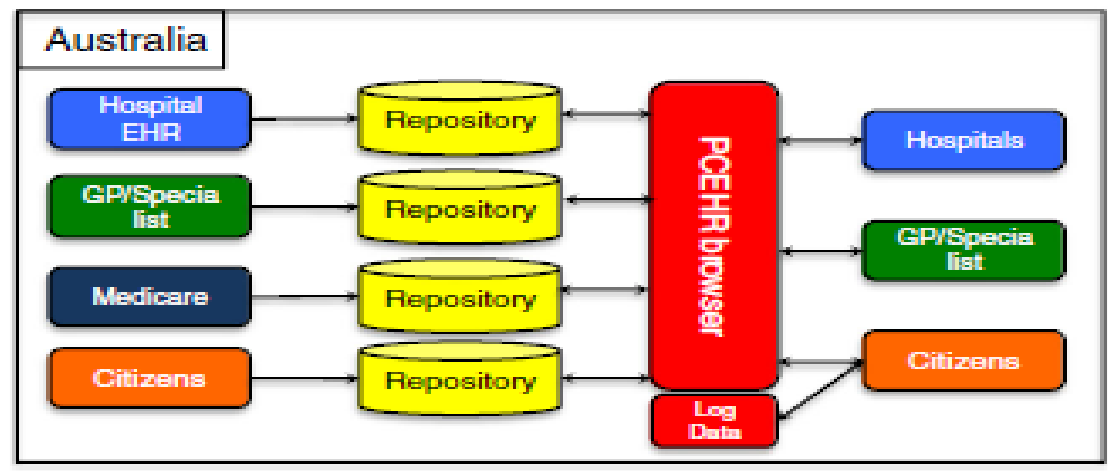

Gambar 6. Arsitektur sistem input, penyimpanan, dan penyajian data dalam sistem E-PHR Australia (Nøhr et al., 2017).

Kemampuan untuk mengumpulkan data-data kesehatan yang tersebar pada beberapa pusat penyimpanan data ini diakomodasi oleh identitas layanan kesehatan individu (Individual Health Identifier/IHI) yang telah disebutkan di atas. Nomer IHI ini berfungsi sebagai penanda pada sistem MyHR pusat yang juga disematkan pada semua data-data milik individual yang sama yang tersebar pada pusat-pusat data lain. Pada saat nomer IHI ini diakses pada sistem MyHR pusat, sistem secara otomatis menghubungkan data-data yang tersebar tersebut untuk disajikan pada pasien (Pearce and Bainbridge, 2014).

Agar dapat terhubung dengan sistem MyHR, sistem eHR dari berbagai penyedia layanan kesehatan tersebut harus memenuhi standar yang ditetapkan peraturan dan undang-undang di mana standar ini mengacu pada kerangka standarisasi informasi kesehatan Health Level Seven (HL7) dan disimpan serta dikomunikasikan antar-sistem dalam format XML (ADHA, 2015). 


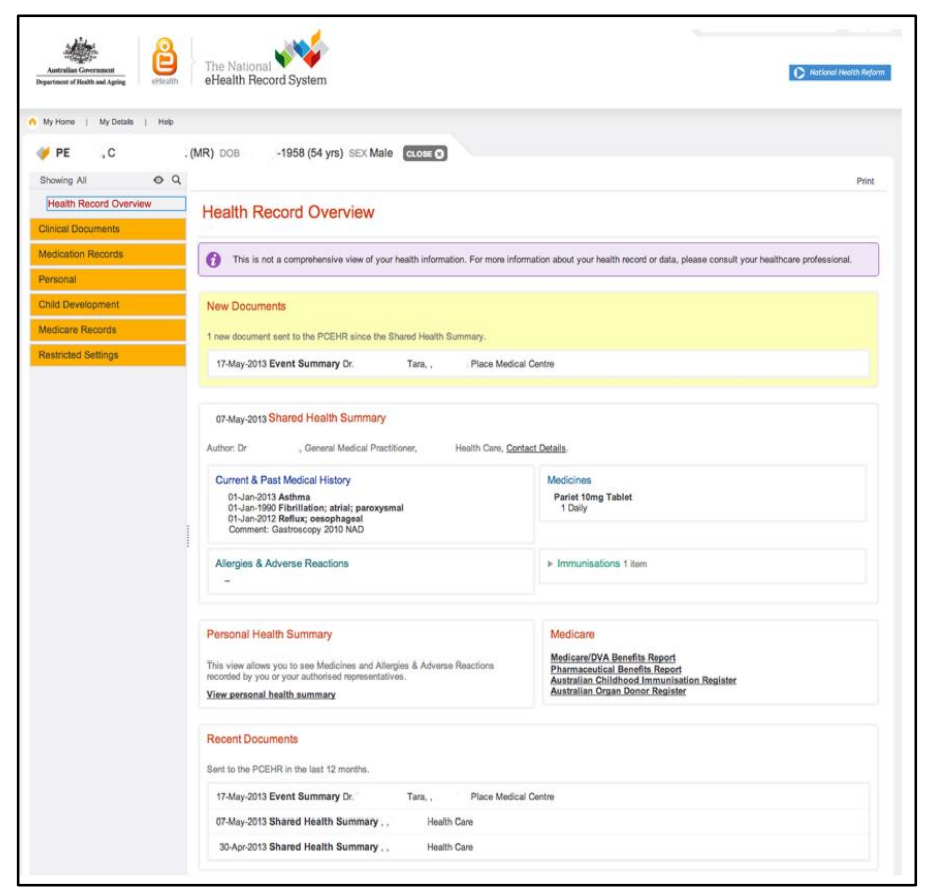

Gambar 7. Tampilan akun pengguna MyHR saat rilis (Pearce and Bainbridge, 2014).

\section{Konten dan Fitur}

Pada saat dilansir tahun 2012, MyHR menerapkan keanggotaan dengan sistem opt-in atau tidak adanya kewajiban bagi individual dan penyedia layanan kesehatan untuk ikut serta dalam program MyHR. Pada 2018, dengan perubahan undang-undang, keanggotaan MyHR berubah menjadi opt-out. Dengan sistem baru ini, semua individu di Australia akan mendapatkan akun MyHR secara otomatis. Warga yang tidak berkenan menjadi anggota, dapat mengajukan pengecualian dalam batas waktu tertentu.

Bagi pengguna MyHR sendiri, program ini menyediakan layanan penyajian informasi rekam medis pribadi, dan terdapat fitur kendali akses terhadap akun dan dokumen-dokumen spesifik yang tersaji dalam akun MyHR mereka. Mekanisme penyajian informasi sendiri dibagi menjadi dua: beberapa informasi disajikan sebagai read only atau tidak dapat dimodifikasi oleh pengguna, sementara beberapa informasi lainnya bersifat modifiable atau dapat dimodifikasi oleh pengguna (Nøhr et al., 2017). 
Informasi yang bersifat modifiable adalah informasi pribadi yang dapat meliputi riwayat alergi, efek samping obat yang pernah dirasakan, obat-obatan yang dikonsumsi saat ini, monitoring kesehatan pribadi, riwayat diet, dan informasi lain yang relevan dalam layanan kesehatan. Informasi pribadi ini tidak otomatis dapat dilihat oleh tenaga medis yang melayani pasien, akan tetapi pasien dapat membagi akses terhadap informasi tersebut pada tenaga medis apabila dirasa perlu. Di lain pihak, informasi lain bersifat read only bagi pasien. Informasi read only ini dapat meliputi riwayat imunisasi, ringkasan kunjungan rawat jalan, ringkasan rawat inap, dan hasil pemeriksaan penunjang (Nøhr et al., 2017).

Tabel 4. Tingkat akses pengguna MyHR terhadap jenis-jenis informasi kesehatan

\begin{tabular}{ll} 
Jenis Informasi & Tingkat Akses \\
\hline Riwayat alergi & Modifiable \\
Obat yang dikonsumsi saat ini & Modifiable \\
Catatan kesehatan pribadi & Modifiable \\
Ringkasan kunjungan rawat jalan & Read only \\
Ringkasan rawat inap & Read only \\
Hasil laboratorium & Read only \\
Hasil pencitraan diagnostik & Read only
\end{tabular}

Pasien tetap berkuasa atas informasi-informasi yang bersifat read only. Kuasa pasien ini dilihat dari adanya fitur penghapusan dokumen tersebut dari sistem MyHR (Pearce and Bainbridge, 2014). Akan tetapi, harus disadari bahwa penghapusan dari sistem MyHR ini tidak berarti data tersebut dihapus dari pusat penyimpanan data. Seperti telah dibahas di atas, sistem MyHR hanya bersifat sebagai pencatat, pengelola, dan penyaji informasi kesehatan. File-file informasi itu sendiri disimpan dalam repository atau pusat penyimpanan data yang sifatnya tersebar. Data dalam repository ini tidak terpengaruh saat sajian data dalam sistem MyHR dihapus. Data dalam sistem eHR penyedia layanan kesehatan yang terhubung dengan repository tersebut juga tidak terhapus saat sajian informasi yang sama dihapus dari sajian MyHR (Robert, no date). 
Dalam hal kendali akses, akun peserta MyHR dapat diakses oleh dua pihak: peserta pemilik akun tersebut dan tenaga medis yang menangani pasien tersebut. Selain itu, peserta dapat menetapkan wali (representative) yang juga dapat mengakses informasi dalam akun MyHR-nya walaupun wali tersebut bukan merupakan tenaga medis. Pemilik akun dapat mengendalikan tingkat akses masing-masing penyedia layanan kesehatan dan wali, mulai tingkat umum dan terbatas. Tingkat akses ini berpengaruh pada pembatasan akses dokumen yang akan dibahas selanjutnya.

Selain kendali akses terhadap akun, peserta juga dapat mengendalikan akses terhadap masing-masing dokumen dalam akun tersebut. Tingkat pembatasan akses dokumen dibagi menjadi 3 tingkat: akses umum, akses terbatas, dan tersembunyi. Dokumen dengan akses umum dapat dilihat oleh semua penyedia layanan kesehatan dan wali, akan tetapi dokumen dengan akses terbatas hanya dapat dilihat oleh penyedia layanan kesehatan dan wali yang ditetapkan berhak melihat dokumen akses terbatas oleh pemilik akun. Terakhir, dokumen tersembunyi tidak dapat dilihat siapa pun, termasuk pemilik akun. Dokumen tersembunyi hanya dapat dilihat setelah dokumen tersebut dikembalikan (restore) ke tingkat akses umum atau terbatas (MyHR, 2019b).

\section{Tanggapan Pengguna}

Seperti sudah dijelaskan di atas, pada awal implementasi MyHR kepesertaan bersifat opt-in atau atas inisiatif masyarakat sendiri. Pada masa awal ini pertumbuhan kepesertaan rendah. Pada 7 bulan pasca rilis, kepesertaan hanya mencapai sekitar 50 ribu peserta, sementara target pada bulan kedua belas adalah 500 ribu peserta (Hilvert, 2013). Sejak perubahan undang-undang yang menjadikan kepesertaan MyHR bersifat opt-out, tingkat kepesertaan MyHR meningkat pesat. Pada Juli 2019, kepesertaan MyHR meliputi 90,1\% dari penduduk Australia dan terhubung dengan 16.400 institusi penyedia layanan kesehatan (MyHR, 2019a).

Beberapa penelitian yang mempelajari rendahnya kepesertaan MyHR sebelum berubah menjadi opt-out menyatakan bahwa persepsipersepsi masyarakat mempengaruhi kecenderungan untuk menjadi peserta. Promosi MyHR dianggap kurang, menyebabkan kesadaran masyarakat akan keberadaan MyHR dan fitur-fiturnya menjadi rendah. 
Rendahnya kesadaran ini berpengaruh pada persepsi masyarakat terhadap manfaat dari menjadi peserta MyHR yang secara langsung berkontribusi pada keputusan untuk mendaftar atau tidak mendaftar. Selain itu, kepercayaan masyarakat terhadap keaman dan privasi penyimpanan data pribadi secara elektronik juga mengalami penurunan pada tahun-tahun menjelang rilisnya MyHR. Skeptisisme masyarakat terhadap keamanan dan privasi data dalam MyHR, di mana data kesehatan ini bersifat sensitif, juga berpengaruh terhadap keputusan untuk menjadi peserta (Kasteren et al., 2017).

Untuk orang-orang yang sudah menjadi peserta dan pengguna dari layanan MyHR, tanggapan yang muncul cukup positif. Pada salah satu penelitian kualitatif, pengguna menyatakan merasakan manfaat MyHR terutama dari fitur pembagian informasi antar tenaga medis. Hal ini dirasakan bermanfaat bagi pengguna dengan gaya hidup atau pekerjaan yang mengharuskan mobilitas yang tinggi sehingga menyebabkan pengguna berurusan dengan beberapa penyedia layanan kesehatan. MyHR menyebabkan informasi medis pengguna dari satu penyedia layanan kesehatan dapat dikomunikasikan ke penyedia layanan kesehatan lainnya (Lupton, 2019). Manfaat ini juga dinyatakan oleh pengguna dalam penelitian lain yang mengatakan bahwa kemampuan pemindahan informasi dari penyedia layanan kesehatan lain ini bermanfaat saat mengunjungi suatu penyedia layanan kesehatan untuk pertama kali. Pengguna juga merasa semakin berkuasa atas kesehatan sendiri akibat tingginya akses terhadap hasil-hasil pemeriksaan terhadap diri sendiri (Hanna et al., 2017).

Penelitian pada tenaga kesehatan juga menunjukkan sebagian besar tenaga kesehatan merasakan manfaat dari sistem MyHR. Manfaat dirasakan dari kemudahan akses terhadap riwayat medis pasien yang ditangani. Akan tetapi tetap terdapat beberapa kekhawatiran mengenai perlambatan waktu pelayanan akibat harus menggunakan sistem daring MyHR. Dokter juga memiliki kekhawatiran akan berkurangnya independensi klinis akibat pengawasan yang lebih ketat dari institusi melalui sistem MyHR (Muhammed and Wickramasinghe, 2017). Kekhawatiran ini sepertinya cukup besar pada beberapa dokter hingga ada pengguna yang mengaku dihalangi untuk menjadi peserta MyHR oleh dokter keluarganya (Lupton, 2019). 


\section{Sistem E-PHR di Indonesia}

\section{Regulasi Perundang-undangan yang Mengatur E-PHR}

Tidak terdapat peraturan spesifik mengenai E-PHR dalam peraturan dan perundang-undangan di Indonesia. Akan tetapi, kita dapat menganalisa peraturan yang berlaku untuk E-PHR dengan menganalisa peraturanperaturan yang berlaku terhadap komponennya, terutama rekam medis elektronik (eMR) sebagai sumber utama data untuk eHR dan PHR.

Pengembangan E-PHR di Indonesia sendiri diselenggarakan dalam kerangka pengembangan sistem informasi kesehatan sebagaimana diamanatkan dalam Pasal 168 Undang-undang no. 36 tahun 2009 tentang Kesehatan. Amanat dalam Pasal 168 ini kemudian dikejewantahkan dalam bentuk peraturan pemerintah, sebagaimana diamanatkan, yaitu Peraturan Pemerintah (PP) Republik Indonesia no. 46 tahun 2014 tentang Sistem Informasi Kesehatan. PP no. 46 tahun 2014 ini kemudian menjadi pertimbangan dalam penerbitan Peraturan Menteri Kesehatan no. 46 tahun 2017 tentang Strategi E-Kesehatan Nasional.

UU no. 36 tahun 2009 tentang Kesehatan dan PP no. 46 tahun 2014 tentang Sistem Informasi Kesehatan hanya membahas informasi kesehatan dalam konteks data agregat yang berperan dalam penyusunan kebijakan kesehatan, akan tetapi tidak membahas sistem informasi kesehatan dalam tingkat layanan kesehatan yang relevan dalam tinjauan ini. Sementara itu, Permenkes no. 46 tahun 2017 tentang Strategi E-Kesehatan Nasional membahas secara garis besar tentang strategi e-kesehatan dalam bidang layanan kesehatan yang mencakup eMR dan PHR. Akan tetapi, Permenkes no. 46 tahun 2017 ini juga membahas eMR dan PHR secara garis besar tanpa memaparkan petunjuk teknis mengenai penerapannya di lapangan.

Untuk petunjuk teknis ini kita dapat merujuk pada Peraturan Menteri Kesehatan no. 269 tahun 2008 tentang Rekam Medis yang memaparkan kaidah-kaidah pelaksanaan rekam medis seperti isi rekam medis serta kaidah mengenai kerahasiaan rekam medis. Dalam kaitannya dengan E-PHR, dalam Pasal 2 Permenkes no. 269 tahun 2008 tentang Rekam Medis, secara spesifik disebutkan bahwa penyelenggaraan rekam medis dalam media elektronik akan diatur lebih lanjut dalam peraturan tersendiri. Permasalahannya, hingga saat ini belum ada peraturan perundang- 
undangan yang secara spesifik membahas penyelenggaraan rekam medis elektronik atau eMR.

Untuk mengisi kekosongan peraturan ini, kita dapat sebagian mengacu pada Peraturan Menteri Kesehatan no. 82 tahun 2013 tentang Sistem Informasi Manajemen Rumah Sakit dan Undang-Undang no. 19 tahun 2016 tentang perubahan atas Undang-undang Informasi dan Transaksi Elektronik (ITE). Permenkes no. 82 tahun 2013 mengatur bahwa dalam pelaksanaan Sistem Informasi Manajemen Rumah Sakit (SIMRS), sistem tersebut mencakup juga rekam medis di dalamnya sehingga menjadi dasar hukum pelaksanaan rekam medis elektronik di rumah sakit. Peraturan terkait untuk puskesmas tertuang dalam Peraturan Menteri Kesehatan no. 75 tahun 2014 tentang Pusat Kesehatan Masyarakat (Puskesmas). Akan tetapi, interpretasi mengenai pelaksanaan eMR dalam sistem informasi puskesmas (SIP) berdasarkan Permenkes no. 75 tahun 2014 ini kurang jelas. Dalam ketidakjelasan ini, terdapat argumen bahwa pengembangan sistem eMR dan eHR dapat dilakukan dengan menggunakan Undang-undang no. 19 tahun 2016 sebagai perubahan atas Undang-undang Informasi dan Transaksi Elektronik (UU ITE) sebagai paying hukumny a. Walaupun UU ITE tidak secara spesifik mengatur pelaksanaan eMR, (Sudjana, 2017) berpendapat bahwa eMR dapat dikategorikan sebagai dokumen elektronik dengan otentikasi tenaga medis berupa tanda tangan digital. Pendapat ini juga disetujui (Amir, 2019) yang mengatakan pelaksanaan eMR diakui dalam Permenkes no. 269 tahun 2008 tentang Rekam Medis dan dipandang sebagai sebuah dokumen elektronik. 
Tabel 5. Peraturan dan perundang-undangan yang relevan dalam pengembangan eMR dan eHR sebagai sumber data E-PHR

\begin{tabular}{|c|c|}
\hline Peraturan & Relevansi \\
\hline UU no. 36 tahun 2009 tentang Kesehatan & $\begin{array}{l}\text { Mengamanatkan pengembangan sistem } \\
\text { informasi kesehatan dan peraturan } \\
\text { mengenai rekam medis }\end{array}$ \\
\hline $\begin{array}{l}\text { UU no. } 19 \text { tahun } 2016 \text { tentang perubahan } \\
\text { UU Informasi dan Transaksi Elektronik } \\
\text { (ITE) }\end{array}$ & $\begin{array}{l}\text { Mengatur transaksi dan dokumen } \\
\text { elektronik. Rekam medis elektronik dapat } \\
\text { dipandang sebagai dokumen elektronik. }\end{array}$ \\
\hline $\begin{array}{l}\text { Permenkes no. } 46 \text { tahun } 2017 \text { tentang } \\
\text { Strategi E-Kesehatan Nasional }\end{array}$ & $\begin{array}{l}\text { Salah satu strategi e-kesehatan nasional } \\
\text { dalam bidang pelayanan kesehatan adalah } \\
\text { pengembangan eMR dan PHR }\end{array}$ \\
\hline $\begin{array}{l}\text { Permenkes no. } 269 \text { tahun } 2008 \text { tentang } \\
\text { Rekam Medis }\end{array}$ & $\begin{array}{l}\text { Mengatur pelaksanaan rekam medis secara } \\
\text { umum. Mengakui eksistensi rekam medis } \\
\text { elektronik (eMR). }\end{array}$ \\
\hline $\begin{array}{l}\text { Permenkes no. } 82 \text { tahun } 2013 \text { tentang } \\
\text { Sistem Informasi Manajemen Rumah } \\
\text { Sakit (SIMRS) }\end{array}$ & $\begin{array}{l}\text { Mengatur pelaksanaan rekam medis } \\
\text { elektronik sebagai bagian dari SIMRS }\end{array}$ \\
\hline $\begin{array}{l}\text { Permenkes no. } 75 \text { tahun } 2014 \text { tentang } \\
\text { Puskesmas }\end{array}$ & $\begin{array}{l}\text { Mengatur pelaksanaan sistem informasi } \\
\text { puskesmas dan rekam medis di } \\
\text { puskesmas. Posisi rekam medis elektronik } \\
\text { dalam sistem informasi puskesmas tidak } \\
\text { jelas. }\end{array}$ \\
\hline
\end{tabular}

Sementara itu, akses pasien terhadap isi dari informasi kesehatan pribadinya, esensi dari sistem E-PHR, telah secara lebih jelas diatur dalam beberapa peraturan dan perundang-undangan. Dalam Pasal 47 Undangundang no. 29 tahun 2004 tentang Praktik Kedokteran diatur bahwa pasien memiliki hak kepemilikan atas isi informasi yang terkandung dalam rekam medis yang dibuat dokter yang menanganinya. Norma yang sama juga tertuang dalam Undang-undang no. 44 tahun 2009 tentang Rumah Sakit yang mengatur bahwa segala informasi yang ditemukan dokter dalam rangka pengobatan dicatat dalam rekam medis, menjadi milik pasien, dan bersifat rahasia.

Terkait dengan dua undang-undang di atas, Kementerian Kesehatan Republik Indonesia kemudia mengejawantahkannya dalam bentuk 
peraturan menteri kesehatan. Dalam Peraturan Menteri Kesehatan no. 269 tahun 2008 tentang Rekam Medis yang mengatur bahwa isi rekam medis, yang diwujudkan dalam ringkasan rekam medis, adalah milik pasien. Dalam pasal 10 dari Permenkes no. 269 tahun 2008 juga diatur mengenai kerahasiaan rekam medis yang informasi di dalamnya hanya boleh diakses oleh pasien, keluarga yang berhak, dan/atau orang yang diberi kuasa. Penjagaan kerahasiaan isi rekam medis ini menjadi tanggung jawab tenaga medis dan institusi penyedia layanan kesehatan yang dimandatkan untuk mengupayakan pembatasan akses terhadap rekam medis sebagaimana diatur dalam Peraturan Menteri Kesehatan no. 4 tahun 2018 tentang Kewajiban Rumah Sakit dan Kewajiban Pasien.

Tabel 6. Peraturan dan perundang-undangan yang relevan dalam akses pasien terhadap informasi kesehatan sebagai komponen dari E-PHR

\author{
Peraturan \\ UU no. 29 tahun 2004 tentang Praktik \\ Kedokteran \\ UU no. 44 tahun 2009 tentang Rumah \\ Sakit
}

Permenkes no. 269 tahun 2008 tentang Rekam Medis

Permenkes no. 4 tahun 2018 tentang Kewajibatn Rumah Sakit dan Kewajiban Pasien

Peraturan Presiden no. 95 tahun 2018 tentang Sistem Pemerintahan Berbasis Elektronik (SPBE)

\section{Relevansi}

Mengatur norma kepemilikan berkas rekam medis oleh dokter dan kepemilikan isi rekam medis oleh pasien.

Mengatur informasi yang diperoleh dalam rangka pengobatan adalah milik pasien dan bersifat rahasia.

Mengatur isi rekam medis adalah milik pasien dan dapat diakses pasien dalam bentuk ringkasan rekam medis. Mengatur akses terhadap isi rekam medis dibatasi pada pasien, keluarga pasien, dan/atau orang yang diberi kuasa.

Mengatur kewajibatn dokter dan institusi penyedia layanan kesehatan dalam membatasi akses terhadap rekam medis.

Mengatur pengembangan aplikasi dan sistem elektronik dalam penyelenggaraan pemerintahan dan pelayanan publik.

Peraturan Presiden no. 95 tahun 2018 menambah satu ketentuan mengenai pengembangan sistem informasi atau aplikasi elektronik dalam penyelenggaraan pelayanan publik. Walaupun tidak secara langsung 
berhubungan dengan teknis pelayanan kesehatan dan alur informasi kesehatan pasien, Perpres no. 95 tahun 2018 harus dipertimbangkan dalam penerapan sistem elektronik pada layanan kesehatan publik yang pada intinya merupakan kepanjangan tangan dari penyelenggaraan pemerintahan berbasis elektronik pada tingkat terbawah. Dalam pasal 44 ayat (1) dan (2) diatur bahwa dalam penyelenggaraan layanan publik, termasuk layanan kesehatan, berbasis elektronik pemerintah daerah dapat mengembangkan aplikasi-aplikasi sesuai kebutuhan. Akan tetapi, ayat (3) dan (4) lanjut menjelaskan bahwa pengembangan aplikasi sebagaimana disebutkan harus mendapat masukan dan konsultasi dari menteri terkait.

\section{Fasilitator dan Kendala}

Sama seperti pembahasan mengenai penerapan E-PHR di luar negeri, fasilitator dan kendala penerapan E-PHR di Indonesia menghadapi kendalakendala yang sama dan dapat diklasifikasi menjadi faktor teknis dan faktor pengguna. Faktor teknis meliputi ketersediaan piranti keras dan lunak, ketersediaan sumber daya manusia untuk mengoperasikannya, dan ketersediaan sambungan internet. Seperti yang telah dijabarkan di atas, terdapat kendala dalam hal ketersediaan piranti keras dan lunak dalam pengembangan E-PHR di Indonesia. Kendala ini bukan saja mengenai keterbatasan ketersediaan piranti keras dan lunak secara fisik, yang bervariasi antara daerah satu dan daerah lain, tapi juga karena tidak adanya standardisasi piranti keras dan lunak yang digunakan masing-masing pemangku kepentingan. Pengembangan sistem informasi dilakukan secara sporadis sehingga tidak jarang antara puskesmas dan rumah sakit dalam kabupaten yang sama menggunakan piranti keras dan lunak yang berbeda dalam sistem informasinya. Dalam Permenkes no. 97 tahun 2015 tentang Peta Jalan Sistem Kesehatan tahun 2015-2019 telah diamanatkan pengembangan kamus istilah kesehatan (HDD) yang dapat diakses di http://idn-hdd.kemkes.go.id/ akan tetapi adopsinya masih rendah. Ketersediaan sumber daya manusia untuk pengembangan dan operasi sistem E-PHR juga disebutkan sebagai kendala dalam Permenkes no. 97 tahun 2015 tentang Peta Jalan Sistem Kesehatan tahun 2015-2019 yang menyebutkan masih terbatasnya kemampuan pemerintah daerah untuk mengembangkan sistem informasi kesehatan secara mandiri. 
Sementara itu, ketersediaan internet dapat dilihat sebagai fasilitator. Ketersediaan internet di Indonesia saat ini sudah cukup berkembang dan terus bertumbuh setiap tahunnya. Seperti dilansir Katadata.co.id (2018) berdasarkan laporan kinerja Kementerian Komunikasi dan Informasi, saat ini cakupan koneksi internet 4G di Indonesia telah tersedia di hampir 57\% kecamatan di seluruh Indonesia. Ketersediaan koneksi 4G dari internet service provider (ISP) di Indonesia juga telah tumbuh pesat dengan Telkomsel, XL, Indosat, dan Smartfren telah mampu menyediakan sambungan 4G dengan ketersediaan lebih dari 70\% (Opensignal, 2018). Pemerintah juga telah mencanangkan perluasan ketersediaan sambungan internet pita lebar sebagai salah satu sector pembangunan prioritas. Ketersediaan internet berkecepatan tinggi melalui sambungan pita lebar dan 4G ini penting untuk memfasilitasi adopsi sistem E-PHR yang berbasis internet atau cloud computing pada tingkat akar rumput.

Dari sisi faktor pengguna, terdapat beberapa parameter yang dapat menjadi fasilitator pengembangan sistem E-PHR. Salah satu fasilitator ini, menurut Permenkes no. 97 tahun 2015 tentang Peta Jalan Sistem Kesehatan tahun 2015-2019 adalah tersedianya institusi dan infrastruktur kesehatan yang memiliki cakupan luas. Jaringan puskesmas di Indonesia memiliki jejaring hingga ke tingkat desa/kelurahan, sehingga sebagian besar masyarakat memiliki akses secara fisik terhadap sistem layanan kesehatan. Instalasi sistem E-PHR hanya pada jaringan puskesmas sudah dapat mencapai cukup banyak masyarakat. Hal ini berbeda dengan temuan di Amerika Serikat yang sistem layanan kesehatannya sangat bergantung pada penyedia layanan kesehatan swasta dengan masing-masing organisasi penyedia layanan membawahi sedikit klinik dalam jaringannya. Akibatnya, diperlukan instalasi sistem E-PHR pada lebih dari 26.000 organisasi penyedia layanan kesehatan untuk cakupan E-PHR dapat mencapai 80\%, menggelembungkan biaya yang diperlukan untuk pengembangan sistem (Shah et al., 2008). 
Tabel 7. Faktor-faktor fasilitator dan kendala pengembangan E-PHR di Indonesia

Faktor Teknis Faktor Pengguna

Fasilitator:

- Ketersediaan sambungan internet yang luas secara geografis ditunjang program pemerintah untuk semakin memperluas cakupan tersebut.

\section{Kendala}

- Kurangnya piranti keras dan lunak untuk menunjang operasi.

- Kurangnya standarisasi piranti keras dan lunak tersebut.

- Kurangnya SDM untuk pengembangan dan pelaksanaan secara mandiri.

\section{Fasilitator:}

- Penggunaan internet yang tinggi.

- Infrastruktur kesehatan dengan jaringan yang mencapai hingga desa/kelurahan dan cakupan luas pada masyarakat.

\section{Kendala}

- Ketidaksiapan SDM tenaga kesehatan untuk beralih ke rekam medis elektronik.

Penggunaan internet di Indonesia yang tinggi juga dapat dilihat sebagai fasilitator adopsi sistem E-PHR. Hasil penelitian terakhir oleh (Asosiasi Penyelenggara Jasa Internet Indonesia (APJII), 2017) pada 2018 menemukan pengguna Internet di Indonesia mencapai 171 juta jiwa atau $64,8 \%$ dari seluruh penduduk Indonesia. Angka ini tumbuh pesat dibandingkan temuan pada 2017 yang menemukan pengguna internet di Indonesia mencapai 143 juta jiwa, dan diperkirakan masih akan tumbuh ke depannya (APJII, 2018). Analisa dalam Permenkes no. 97 tahun 2015 tentang Peta Jalan Sistem Kesehatan tahun 2015-2019 juga menyebutkan tingginya penggunaan internet dalam kegiatan komersial di Indonesia menunjukkan kesiapan masyarakat untuk adopsi sistem informasi elektronik dalam transaksi jasa layanan kesehatan.

Dari segi penggunaan oleh tenaga kesehatan, belum terdapat data yang cukup untuk digeneralisasi pada tingkat nasional. Akan tetapi, peneitian sporadis pada beberapa rumah sakit yang sudah menerapkan 
eMR masih menunjukkan adanya kendala. Salah satu indikator keberhasilan penerapan sistem eMR adalah kelengkapan pengisian rekam medis elektronik tersebut. Beberapa penelitian di rumah sakit-rumah sakit berbeda menemukan masih adanya ketidaklengkapan pengisian rekam medis elektronik (Librianti, Rumenengan and Hutapea, 2019). Sementara itu, penelitian pada beberapa rumah sakit yang berencana menerapkan sistem eMR, juga ditemukan adanya ketidaksiapan petugas-petugas terkait akibat kurangnya pengentahuan mengenai pelaksanaan eMR tersebut (Sudirahayu and Harjoko, 2016). Seperti telah dibahas di atas, kendalakendala ini harus diatasi sebelum penerapan program E-PHR di masyarakat. Pelajaran dari Inggris dan Singapura menemukan bahwa implementasi EPHR secara perlahan dengan evaluasi berkala dapat meningkatkan keberhasilan program E-PHR dalam mencapai pelayanan kesehatan yang lebih efisien (NEHTA, 2016). 


\section{Feasibilitas penerapan E-PHR \\ Kelayakan Produk (Product feasibility)}

Kompetitor yang tersedia saat ini

\section{e-Puskesmas}

Tabel 8. Kekuatan dan kelemahan e-Puskesmas

\section{Kekuatan}

- Merupakan platform rekam medis dan rekam kesehatan yang robust dengan kolom isian rekam medis yang lengkap.

- Sudah lama digunakan dengan vendor/developer yang berpengalaman menyediakan jasa pengembangan system informasi dan maintenance yang sesuai.

\section{Kelemahan}

- Vendor/developer swasta yang mengembangkan e-Puskesmas membatasi komunikasi dengan BPJS Kesehatan dan Kemenkes sebagai pihak yang menetapkan standar dalam system informasi kesehatan.

- Terkait dengan keterbatasan komunikasi pengembang-pemangku kebijakan, maintenance dan sinkronisasi e-Puskesmas dengan modul system informasi kesehatan yang lain (misalnya PCare) menjadi terhambat. Hal ini dicirikan dengan keterlambatan update e-Puskesmas untuk mempertahankan bridging dengan PCare.

- e-Puskesmas menggunakan pusat data/server milik developer sehingga data rekam medis pasien tidak sepenuhnya dikuasai oleh fasilitas layanan kesehatan atau dinas kesehatan terkait.

e-Puskesmas adalah sistem manajemen pelayanan pasien yang dikembangkan oleh PT Infokes, sebuah perusahaan sistem informasi swasta yang bekerjasama dengan Telkom Indonesia dalam pengembangan sistem informasi dan manajemen pelayanan kesehatan berbasis cloud computing. e-Puskesmas yang beroperasi saat ini adalah e-Puskesmas NG atau Next Generation yang merupakan versi terbaru dari penyempurnaan berkala 
sistem e-Puskesmas. PT Infokes juga telah memiliki kesepakatan dengan BPJS Kesehatan untuk integrasi sistem e-Puskesmas dengan PCare sehingga petugas di layanan tidak perlu melakukan dua kali input data masingmasing untuk PCare dan e-Puskesmas tapi cukup satu kali input pada ePuskesmas.

Sistem e-Puskesmas sendiri memiliki fitur-fitur untuk membantu manajemen pelayanan kesehatan pasien sejak pasien mendaftarkan diri ke puskesmas, menerima pelayanan pada berbagai poli sesuai kebutuhan pasien, dan luaran akhir seperti pembayaran, perujukan, hingga pasien meninggal. Pendaftaran pasien dilakukan pada saat pasien baru datang ke puskesmas dan mengambil antrian. Sistem pendaftaran berbeda bagi pasien yang sudah pernah memeriksakan diri dan memiliki nomer rekam medis di puskesmas tersebut (pasien lama) dibandingkan pasien yang pertama kali memeriksakan diri di tempat tersebut (pasien baru). Bagi pasien lama pendaftaran cukup dilakukan dengan memasukkan data identitas diri yang dapat berupa NIK atau nomer BPJS, selanjutnya sistem akan mengisi kolom data diri pasien secara otomatis. Pada pasien baru petugas harus mengisi data diri pasien secara manual.

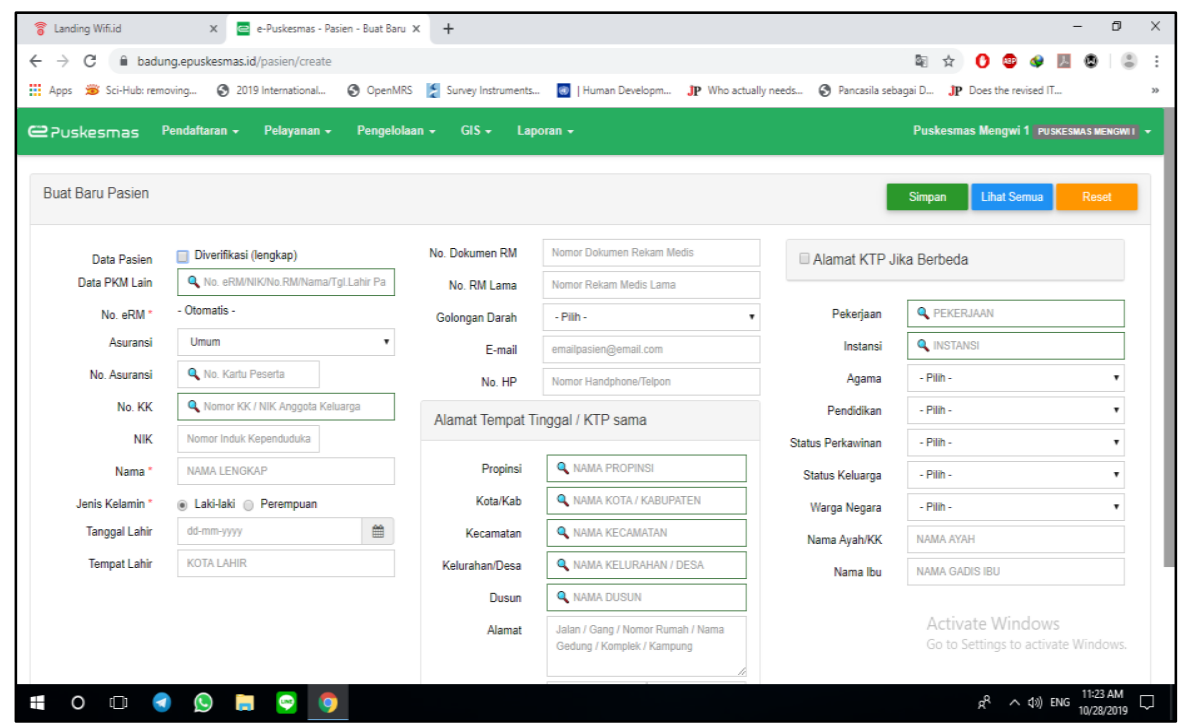

Gambar 8. Tampilan laman pendaftaran pasien baru di e-Puskesmas

Pada laman pendaftaran juga pasien dipilah-pilah berdasarkan poli yang dituju. Pertama-tama pasien dipilah berdasarkan tujuan kunjungan yaitu kunjungan sakit (berobat) dan kunjungan sehat (imunisasi, 
pemeriksaan kesehatan, dll). Pasien juga dipilah berdasarkan poli yang dituju sebelum masuk dalam sistem antrian dalam sistem e-Puskesmas. Laman antrian sendiri menunjukkan daftar semua pasien yang sudah terdaftar di layanan pada hari tersebut dan kode warna menunjukkan apakah pasien tersebut sudah mendapatkan pelayanan, sedang dilayani, atau masih menunggu.

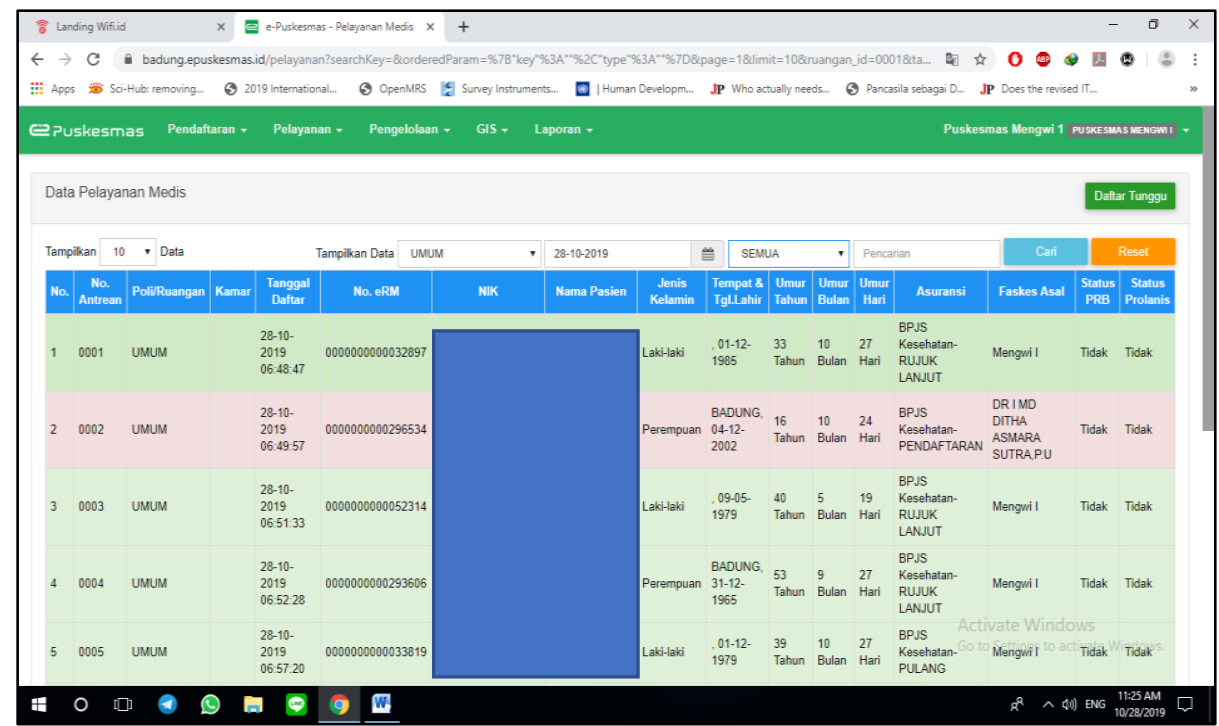

Gambar 9. Tampilan laman antrian dalam sistem e-Puskesmas. Baris warna biru menunjukkan pasien sudah mendapat pelayanan, baris merah muda bagi pasien yang sedang dilayani, dan baris putih menunjukkan pasien masih menunggu.

Ketika pasien mendapat giliran diperiksa, dokter dapat membuka informasi pasien dalam laman layanan. Tampilan awal laman layanan menunjukkan informasi dasar pasien seperti nama, umur, tempat tanggal lahir, dan alamat. Dalam laman tersebut juga terdapat flagging mengenai diagnosis-diagnosis penyakit tertentu seperti riwayat sakit jiwa, penyakit kronis, dan penyakit menular. Pada bagian kiri bawah layar terdapat daftar riwayat kunjungan pasien sebelumnya yang dapat dibuka. Memilih salah satu riwayat kunjungan akan memunculkan pop-up berisi data riwayat kunjungan tersebut yang berisi informasi waktu kunjungan, hasil anamnesis dan pemeriksaan, dan diagnosis. 


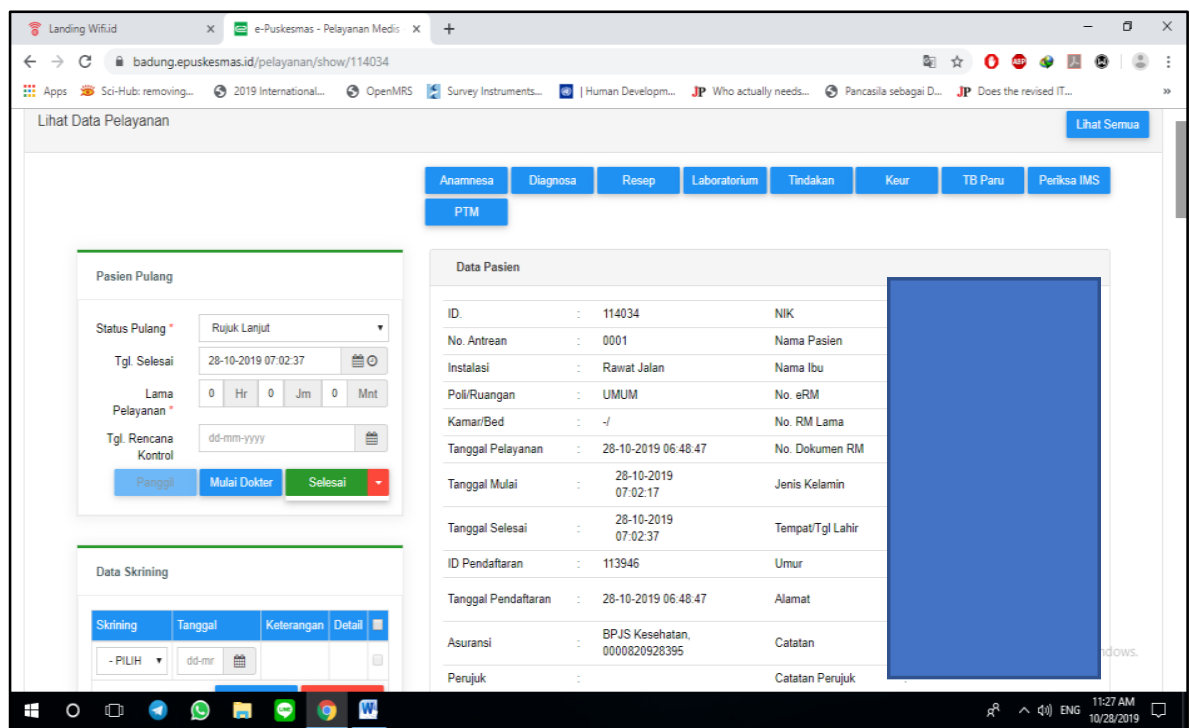

Gambar 10. tampilan laman awal layanan berisi informasi dasar pasien

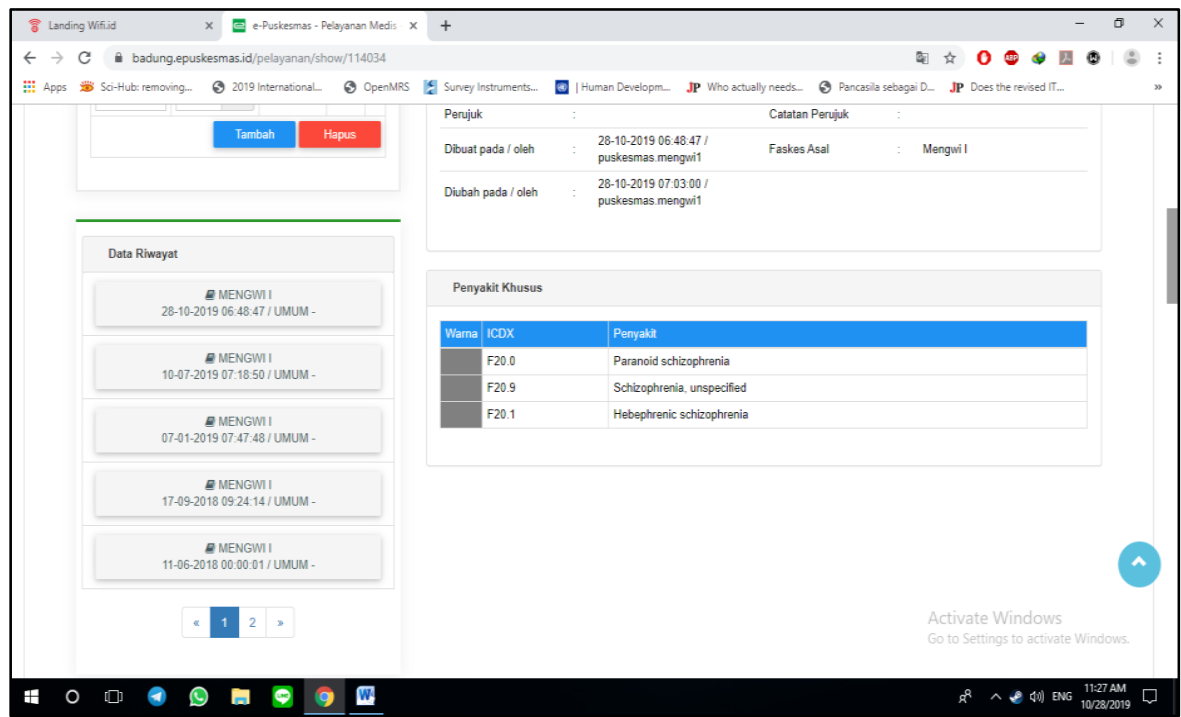

Gambar 11. Flagging penyakit khusus dan riwayat kunjungan (bawah)

Sub-laman anamnesis dari laman layanan berisi kolom-kolom informasi yang dapat diisi oleh petugas. Informasi yang dapat direkam dalam sistem e-Puskesmas sangat lengkap. Saat awal mendapat giliran untuk pelayanan pasien menjalani pemeriksaan tanda vital seperti laju nadi, 
tekanan darah, dan suhu tubuh oleh perawat yang hasilnya dimasukkan dalam sistem e-Puskesmas. Dokter dapat melanjutkan pemeriksaan mulai dari menggali informasi dalam anamnesis dan pemeriksaan fisis umum. Data dari anamnesis yang dapat dicatat dalam sistem e-Puskesmas meliputi keluhan utama, riwayat penyakit sekarang, riwayat penyakit dahulu, dan informasi lain-lain seperti alergi. Sementara itu hasil pemeriksaan fisis dapat dimasukkan berdasarkan sistem organ dan bagian tubuh yang diperiksa. Pada bagian terakhir dari sub-laman anamnesis terdapat body map interaktif di mana dokter dapat mencatat temuan status lokalis seperti ruam, lesi, atau luka yang ditemukan pada pemeriksaan fisis.
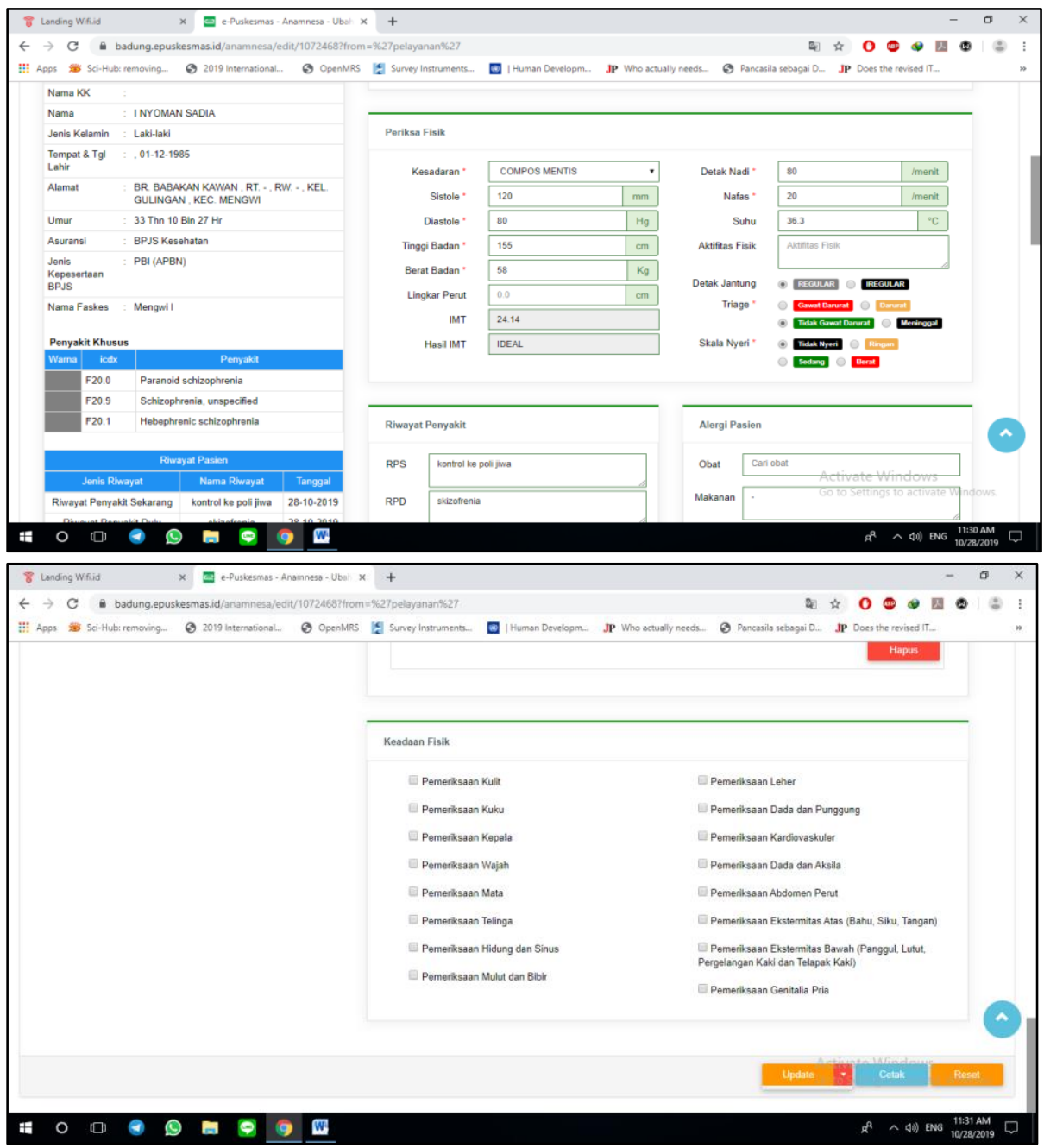

Gambar 12. Sub-laman anamnesis dalam laman layanan di mana petugas dapat merekam hasil pemeriksaan status fisis dan anamnesis 


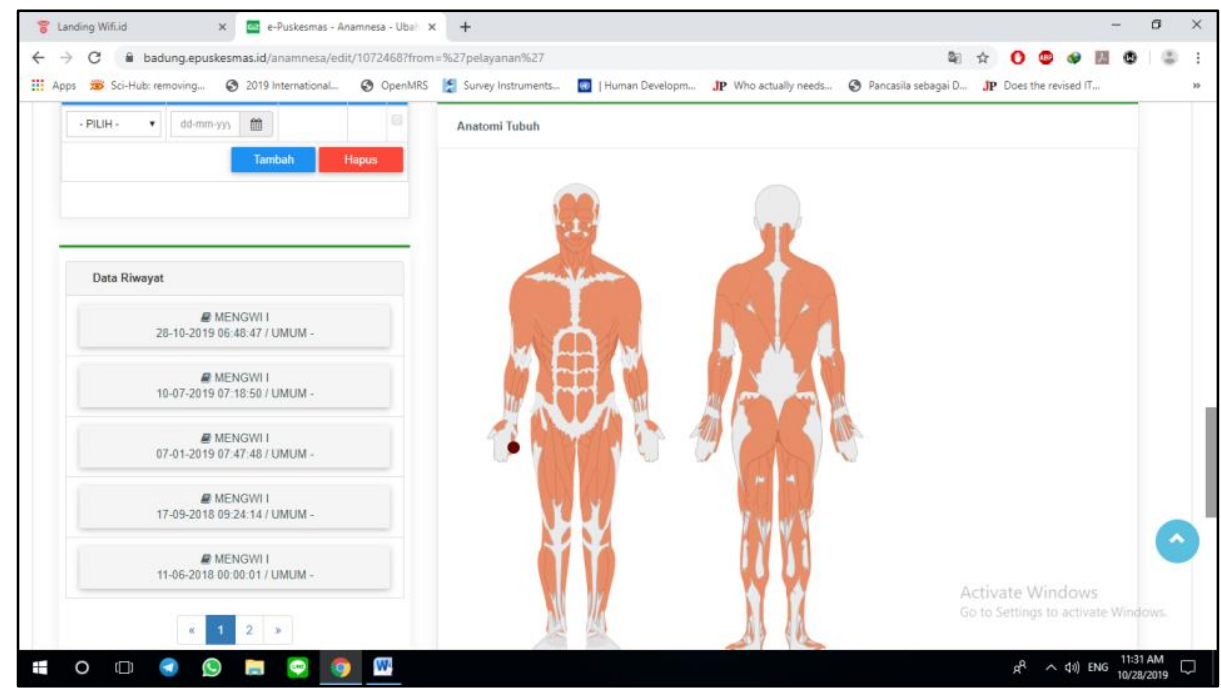

Gambar 13. Sub-laman body map interaktif

Setelah pemeriksaan, dokter bisa memasukkan diagnosis pasien ke dalam sistem e-Puskesmas. Pencatatan diagnosis dilakukan berdasarkan ICD-X dan dimasukkan ke dalam sistem dengan kolom drop down di mana petugas mengetik kata kunci dan sistem akan memunculkan diagnosisdiagnosis yang mungkin berdasarkan kata kunci tersebut. Diagnosis yang direkam dalam sistem dapat lebih dari satu untuk tiap kunjungan. Fitur ini mengantisipasi pasien yang menderita beberapa jenis penyakit, misalnya penyakit kronis dan akut, secara bersamaan.

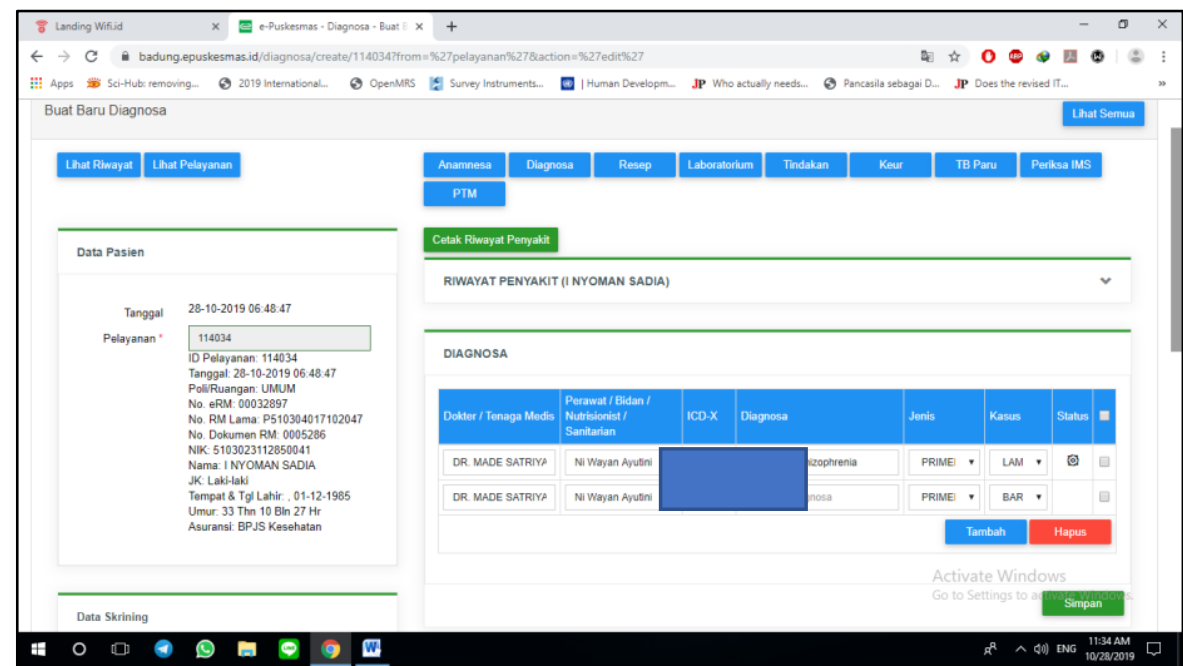

Gambar 14. Laman diagnosis pasien dalam e-Puskesmas. 
Peresepan obat ataupun penanganan pasien melalui tindakan nonfarmakologis juga dapat dicatatat dalam sistem e-Puskesmas. Peresepan obat yang dicatat dalam sistem e-Puskesmas secara otomatis dapat diakses oleh petugas farmasi dalam puskesmas tersebut. Akan tetapi, jika obat tertentu tidak tersedia di bagian farmasi puskesmas, maka peresepan konvensional menggunakan kertas resep harus tetap dilakukan. Tindakan medis yang dicatat dalam sistem e-Puskesmas dilakukan berdasarkan sistem pencatatan tindakan BPJS Kesehatan. Hal ini terkait dengan bridnging e-Puskesmas dan PCare serta berkaitan dengan kepentingan klaim dari puskesmas ke BPJS Kesehatan.
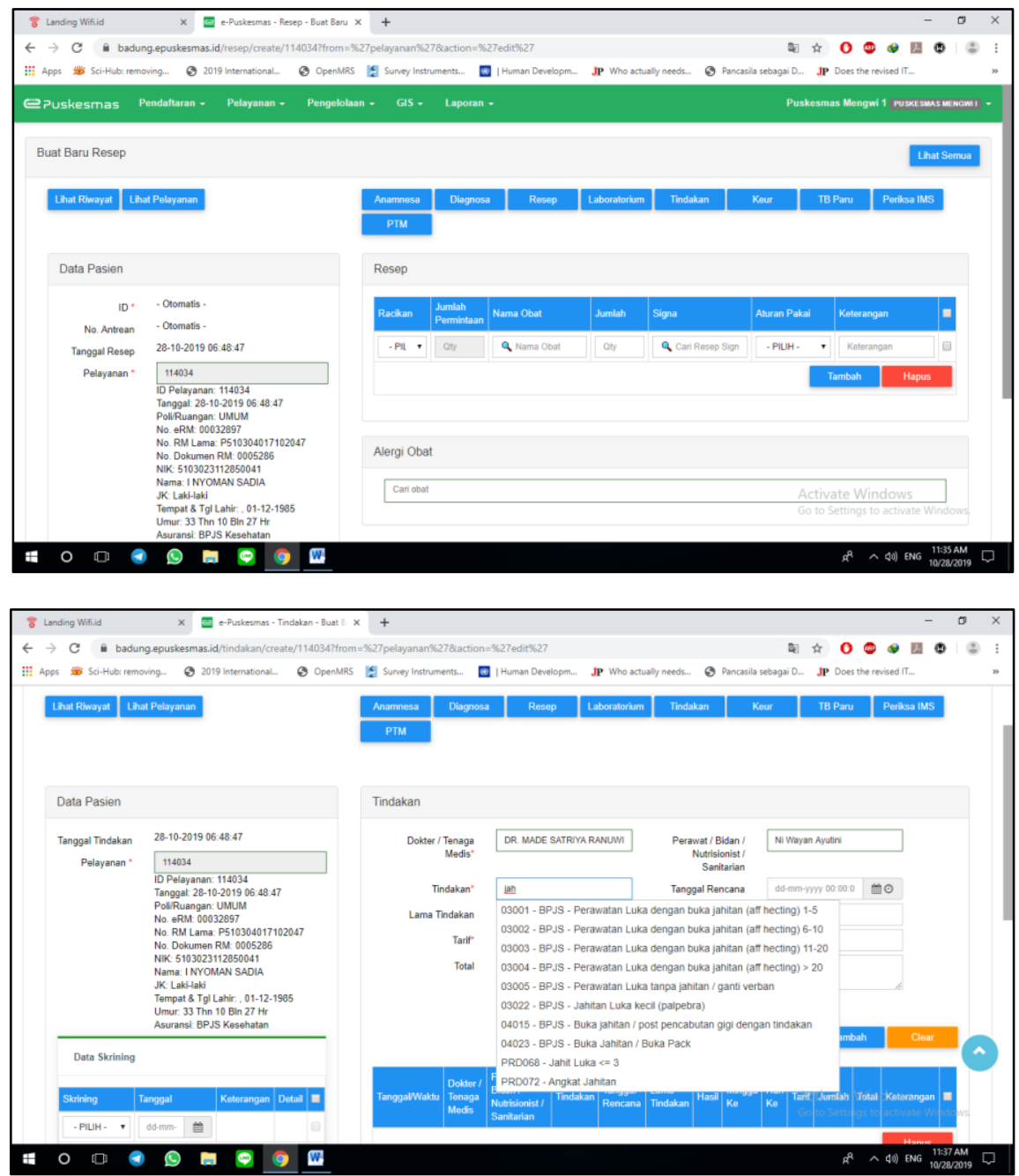

Gambar 15. Laman peresepan obat (atas) dan tindakan medis (bawah) dalam sistem ePuskesmas. 


\section{PCare}

Tabel 9. Kekuatan dan kelemahan P-Care

$\begin{array}{ll}\text { Kekuatan } & \text { Kelemahan } \\ \text { - Merupakan syarat pembayaran } & \text { • Fitur rekam medis sangat terbatas, } \\ \text { kapitasi dari BPJS Kesehatan pada } & \text { hanya terbatas pada format SOAP } \\ \text { FKTP mitra sehingga memiliki } & \text { standar dan tidak bias melakukan } \\ \text { kekuatan memaksa tenaga } & \text { flagging pada pasien dengan } \\ \text { kesehatan di FKTP untuk } & \text { penyakit-penyakit tertentu yang } \\ \text { melengkapi rekam medis PCare. } & \text { harus menjadi perhatian (mis. } \\ \text { - Tersedia secara luas pada semua } & \text { HIV/AIDS, DM, gangguan jiwa, dll). } \\ \text { FKTP mitra BPJS Kesehatan } & \text { - Keamanan data tidak terjamin. Isi } \\ \text { sehingga meningkatkan kekuatan } & \text { riwayat kunjungan, yang } \\ \text { pengumpulan data. } & \text { merupakan parallel rekam medis, } \\ \text { - Terhubung dengan semua system } & \text { dapat diubah sewaktu-waktu oleh } \\ \text { informasi BPJS Kesehatan lainnya } & \text { staff admin IT BPJS Kesehatan. Hal } \\ \text { (Mobile JKN dan VClaim). } & \text { ini melanggar asas penggunaan } \\ & \text { rekam medis sebagai media } \\ & \text { akuntabilitas layanan kesehatan. }\end{array}$

Aplikasi PCare adalah sistem yang dikembangkan Badan Penyelenggara Jaminan Sosial - Kesehatan (BPJS Kesehatan) untuk memudahkan manajemen pasien serta pengumpulan data utilisasi layanan pada tingkat FKTP. Pertama diluncurkan pada 2014, PCare diperbaharui secara berkala dengan frekuensi tinggi untuk memenuhi kebutuhan pengguna serta ketentuan peraturan-peraturan terkait baik dari pemerintah Republik Indonesia maupun ketentuan-ketentuan internal BPJS Kesehatan.

Tingginya frekuensi pembaharuan sistem atau patching ini dapat diilustrasikan dengan fakta bahwa pada Juli 2019 BPJS Kesehatan meluncurkan petunjuk penggunaan PCare ver. 4.0.0 semntara pada Oktober 2019, hanya 3 bulan setelahnya, versi PCare yang aktif digunakan adalah PCare ver. 4.2.0. Hal ini berarti terdapat 2 pembaharuan bermakna dalam kurun waktu kurang dari 3 bulan.

Sistem PCare sendiri merupakan sistem berbasis browser. Pengguna dapat mengakses PCare lewat komputer, laptop, atau alat lain dengan sambungan internet dan aplikasi browser internet melalui URL 
https://pcare.bpjs-kesehatan.go.id/eclaim/Login. Akses ke sistem dilindungi dengan kata sandi dengan pengguna dibagi menjadi dua jenis tingkat akses: petugas date entry di FKTP dan petugas administrator atau admin yang merupakan staf tekonologi intormasi BPJS. Petugas administrator BPJS Kesehatan memiliki tingkat akses yang lebih tinggi terkait dengan tugasnya dalam pemeliharaan sistem serta berwenang mengubah dan menghapus data-data yang dimasukkan petugas data entry, suatu fitur yang tidak tersedia bagi petugas data entry.

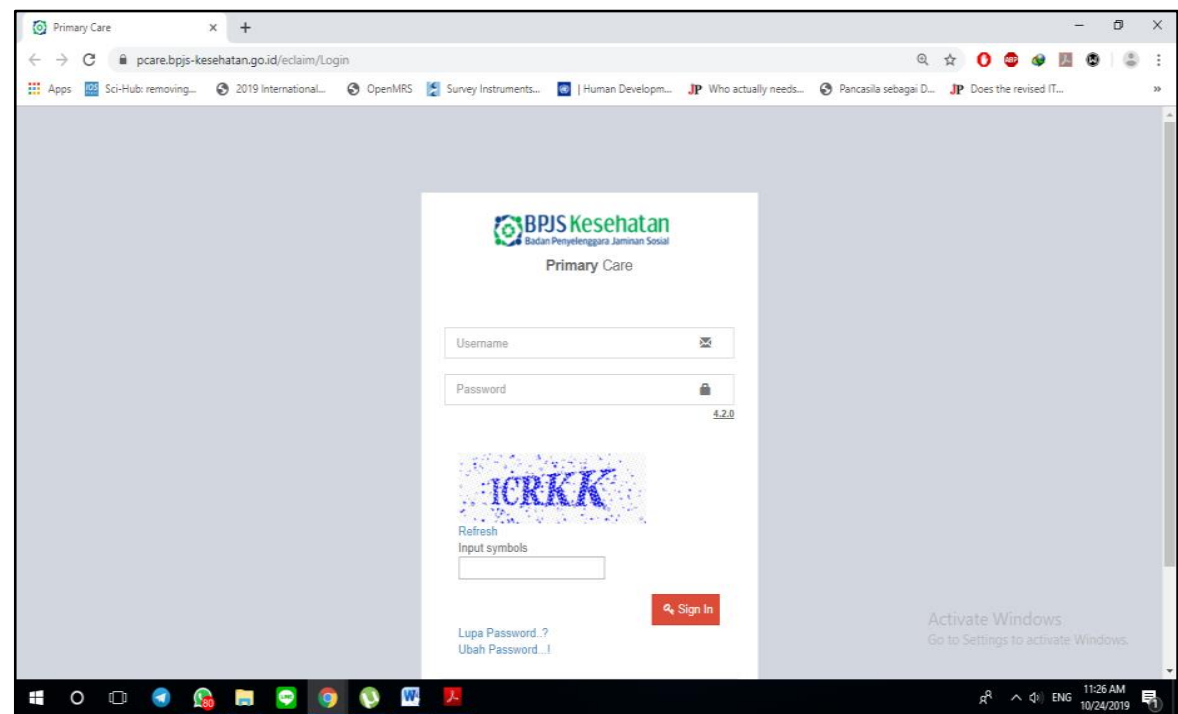

Gambar 16. Tampilan laman awal PCare BPJS Kesehatan

Setelah login, pengguna dapat melihat beberapa layanan yang tersedia dalam sistem PCare. Dalam fungsinya meningkatkan layanan pada pasien, PCare memiliki sistem untuk mengelola pelayanan mulai dari pendaftaran pasien hingga rekam medis terbatas. Berdasarkan pedoman penggunaan PCare ver. 4.0.0, pendaftaran pasien dalam sistem BPJS Kesehatan dilakukan menggunakan nomer peserta BPJS Kesehatan, nomer telepon, atau nomer rekam medis pasien pada FKTP terkait. Pada laman kunjungan petugas juga memasukkan data mengenai tujuan kunjungan serta data-data antropometri dasar dari pasien seperti umur, tinggi dan berat badan, serta pemeriksaan fisis dasar seperti tekanan darah, laju napas, dan laju nadi. 


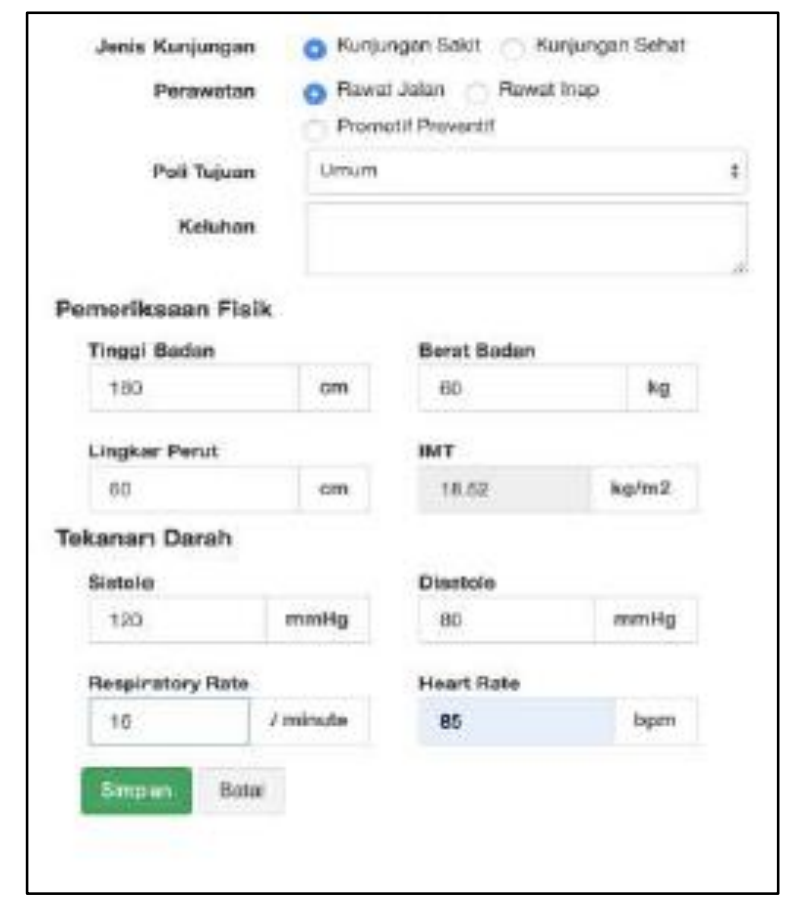

Gambar 17. Tampilan kolom layanan pendaftaran dalam PCare BPJS Kesehatan

Rekam medis terbatas dalam layanan PCare dapat diakses pada saat pasien menerima pelayanan kesehatan. Dalam kolom ini petugas kesehatan dapat memasukkan data-data yang umum dituliskan dalam rekam medis seperti anamnesis, temuan pemeriksaan fisis terbatas, diagnosis, terapi medikamentosa dan non-medikamentosa. Petugas juga dapat memasukkan riwayat pasien seperti riwayat alergi makanan, partikel udara, atau obatobatan. Jika pasien memerlukan layanan yang tidak ditanggung dalam sistem kapitasi, maka petugas dapat memasukkan catatan dilakukannya tindakan tersebut untuk mempermudah FKTP melakukan klaim ke BPJS Kesehatan. 


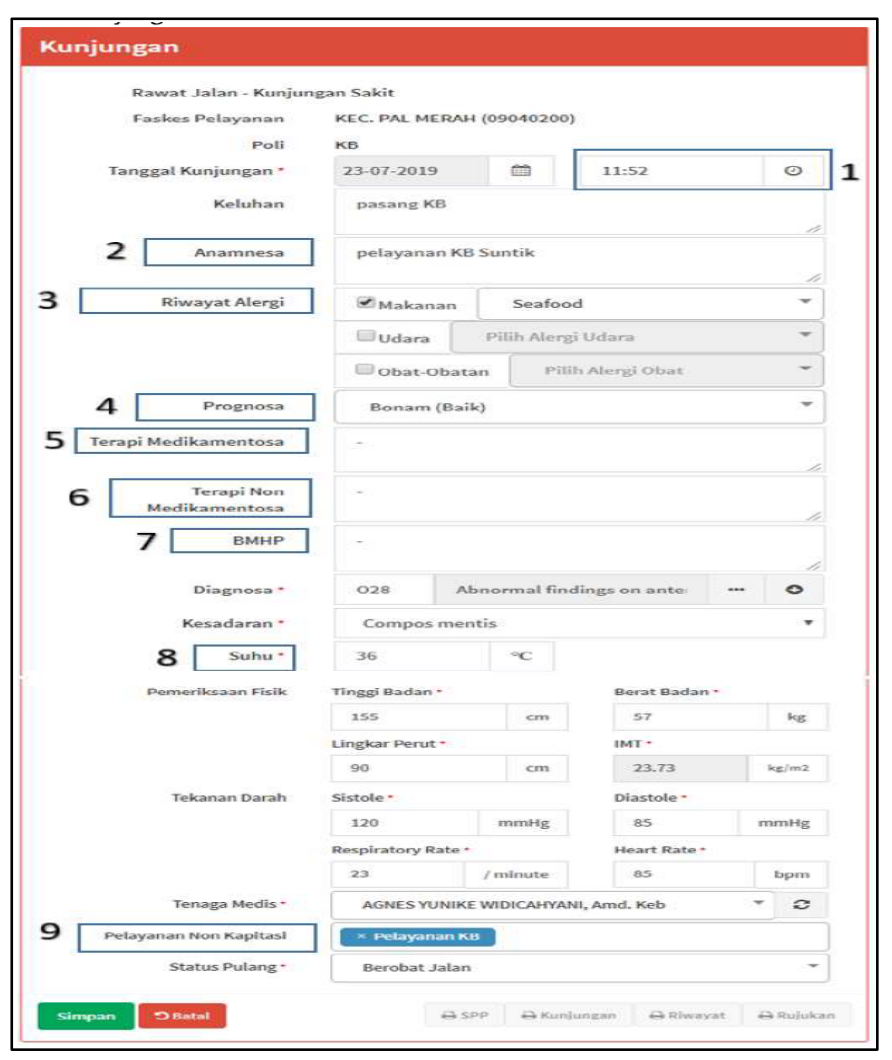

Gambar 18. Tampilan kolom layanan rekam medis terbatas dalam PCare BPJS Kesehatan

Riwayat kunjungan pasien juga dapat diakses dalam fitur ini. Petugas dapat melihat pada sisi kanan layar terdapat daftar riwayat kunjungan pasien ke FKTP yang bekerjasama dengan BPJS Kesehatan dan menggunakan PCare. Petugas FKTP juga dapat mengakses data riwayat kunjungan pasien pada FKTP lain. Pada daftar riwayat kunjungan tersebut petugas dapat melihat teme stamp atau catatan kapan pasien mengunjungi fasilitas layanan kesehatan sebelumnya. Dalam daftar juga tersedia informasi diagnosis pasien pada masing-masing kunjungan tersebut. Jika salah satu riwayat kunjungan tersebut dipilih, petugas dapat mengkases informasi lengkap yang dimasukkan petugas pada saat kunungan tersebut, mulai dari riwayat alergi, anamnesis, hasil pemeriksaan fisis, diagnosis, dan terapi pasien. Fitur ini menunjukkan PCare menunjang adanya komunikasi horizontal antar-FKTP dalam membagi riwayat perawatan pasien. 


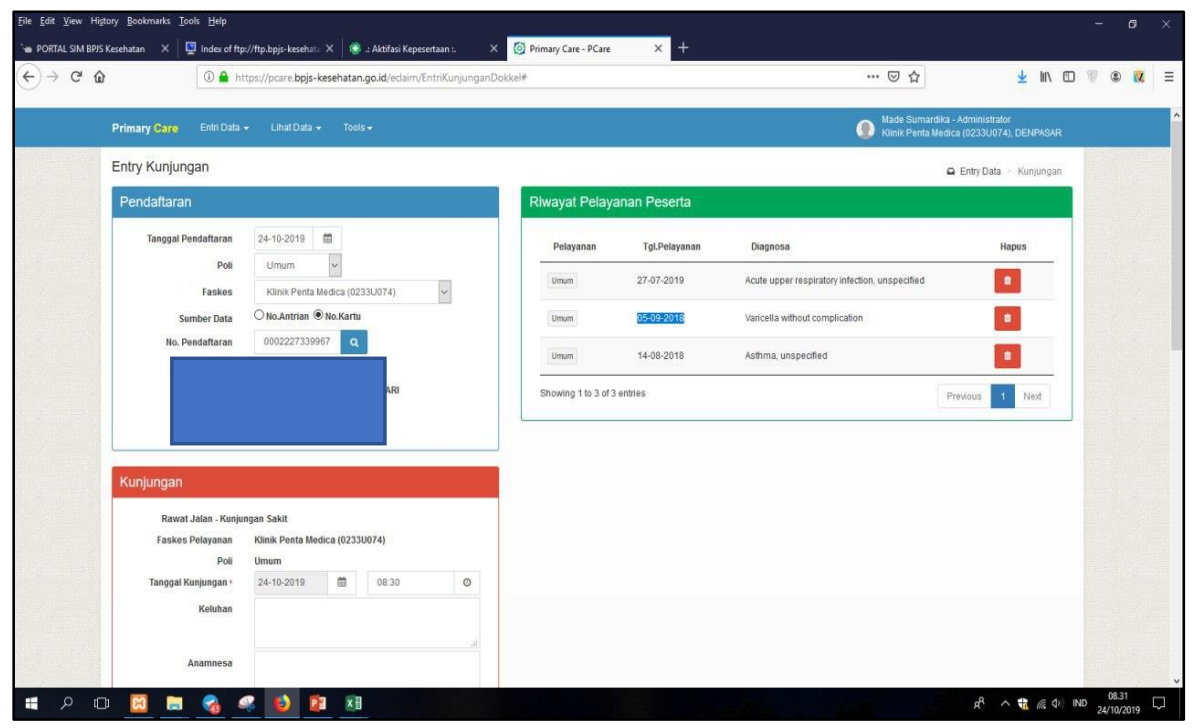

Gambar 19. Tampilan riwayat kunjungan pasien (kotak hijau di sisi kanan layar).

\section{VClaim}

Tabel 10. Kekuatan dan kelemahan V-Claim

\section{Kekuatan}

- Merupakan

Kesehatan, digunakan pada semua rumah sakit mitra BPJS dan menjembatani system informasi FKTP dan rumah sakit mitra BPJS Kesehatan secara terbatas.

\section{Kelemahan}

- Tidak memiliki fitur rekam medis ataupun rekam kesehatan. VClaim hanya berperan sebagai pelengkap system informasi rumah sakit (SIMRS) masing-masing rumah sakit untuk memfasilitasi perujukan dari FKTP dan rumah sakit mitra BPJS serta klaim INACBGs dari rumah sakit ke BPJS.

- Informasi yang dikomunikasikan antara FKTP sangat terbatas, hanya terbatas pada diagnosis di FKTP sebagai indikasi rujukan. Informasi kesehatan lain, seperti riwayat penyakit sebelumnya, riwayat pengobatan, riwayat alergi, dan lain-lain tidak terfasilitasi untuk dikomunikasikan.

VClaim, singkatan dari Virtual Claim, adalah aplikasi online berbasis web atau internet yang dibuat oleh BPJS Kesehatan dengan fungsi utama untuk pembuatan Surat Eligibilitas Peserta (SEP) dan penagihan klaim oleh rumah sakit terhadap BPJS Kesehatan. Dengan deskripsi ini, VClaim tidak difungsikan sebagai electronic health record ataupun rekam medis 
elektronik untuk pasien, akan tetapi terbatas sebagai aplikasi bantu untuk sistem pencatatan tagihan rumah sakit terhadap BPJS Kesehatan.

Pembuatan SEP berfungsi memfasilitasi komunikasi antara fasilitas kesehatan tingkat pertama (FKTP), seperti puskesmas dan klinik pratama, dan fasilitas kesehatan rujukan tingkat lanjut (FKRTL) yaitu rumah sakit. SEP mengkomunikasikan diagnosis rujukan, asal rujukan, serta kelas kepesertaan BPJS pasien sehingga FKRTL dapat menindaklanjuti sebagaimana mestinya. Pembuatan SEP dilakukan berdasar surat rujukan online yang telah dibuat sebelumnya oleh FKTP menggunakan sistem PCare yang terhubung atau bridging dengan VClaim. Dalam pembuatan SEP ini aplikasi VClaim tidak dapat melakukan perubahan terhadap beberapa data yang dikirim dalam rujukan, seperti asal rujukan, poli yang dituju, tanggal dan nomer rujukan. Akan tetapi VClaim masih dapat merubah diagnosis rujukan apabila dirasa tidak sesuai.

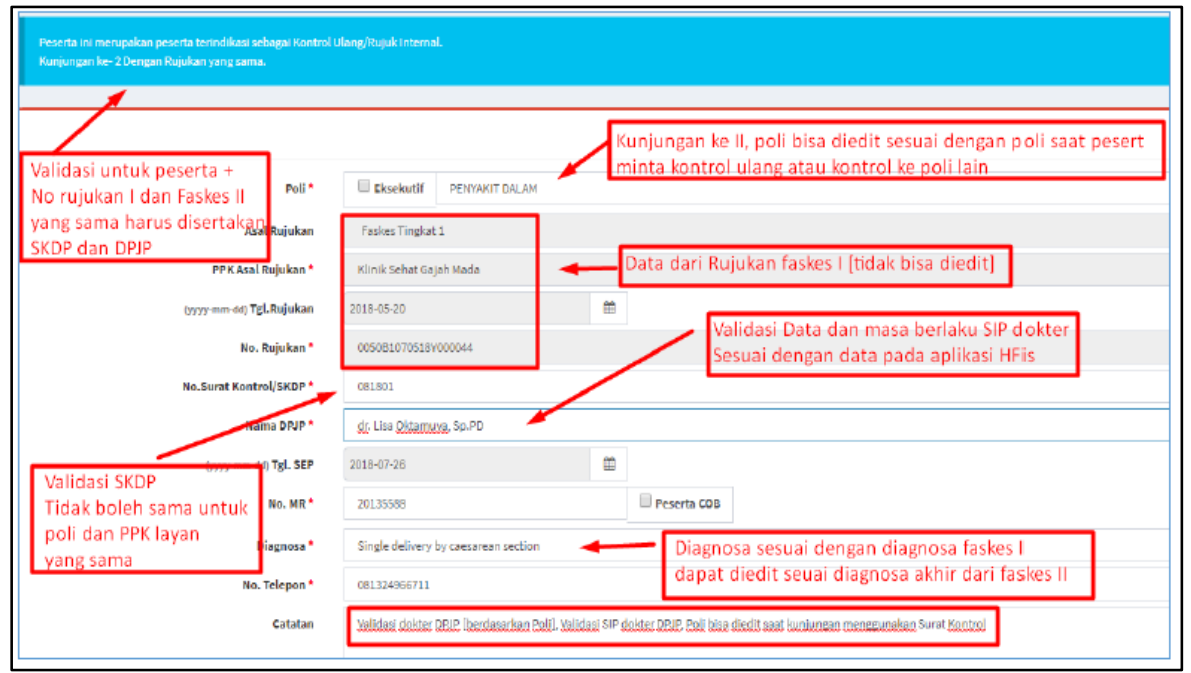

Gambar 20. Tampilan laman pembuatan SEP dalam aplikasi VClaim.

SEP juga bisa dibuat untuk pasien yang akan melanjutkan kontrol di FKRTL. Aplikasi VClaim juga mengakomodasi pembuatan SEP untuk rujukan dari FKTL ke FKTL lain dengan tingkat rujukan lebih tinggi, misalnya untuk pasien yang memerlukan perawatan sub-spesialistik. Untuk pasien yang menjalani perawatan dengan potensi rujuk balik, keterangan tersebut dapat dimunculkan dalam SEP sehingga menjadi pengingat bagi dokter yang 
melayani bahwa setelah pasien terkontrol perawatan lanjutan dapat dikembalikan ke FKTP.

Sebagai kesimpulan, sistem VClaim memiliki keterbatasan fungsi yaitu hanya sebagai media komunikasi antar FKTP, FKTRL, dan BPJS Kesehatan dalam melayani pasien. Informasi yang dikomunikasikan sangat terbatas dan hanya relevan dalam keperluan pengajuan klaim dari fasilitas kesehatan ke BPJS Kesehatan, Aplikasi VClaim tidak memiliki kapasitas rekam medis ataupun health record dan sedari awal tidak di-desain untuk itu. Masing-masing FKTRL yang menggunakan VClaim memiliki sistem rekam medis dan health record masing-masing, terpisah dari VClaim, untuk menunjang pelayanan.

\section{Mobile JKN}

Tabel 11. Kekuatan dan kelemahan Mobile JKN

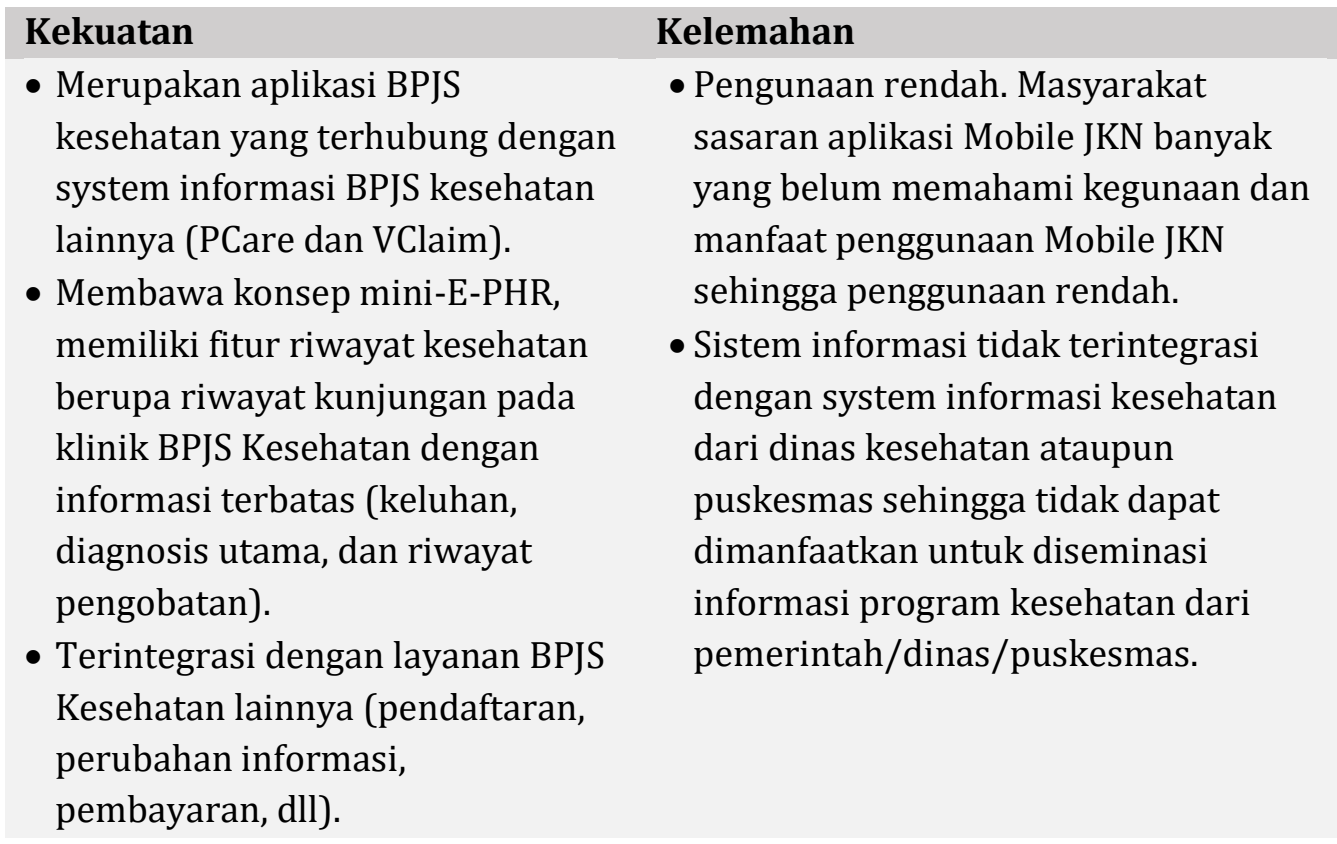

Mobile JKN merupakan aplikasi smartphone yang menyasar peserta BPJS sebagai pengguna. Aplikasi Mobile JKN dapat diperoleh melalui Google PlayStore untuk piranti berbasis Android dan melalui Apps Store untuk piranti Apple. Menurut Panduan Layanan peserta BPJS, aplikasi Mobile JKN bertujuan untuk memudahkan calon peserta mendaftarkan diri serta memudahkan peserta untuk mengubah data pribadi dalam sistem BPJS. 
Mobile JKN juga bertujuan memudahkan peserta untuk mengakses informasi data kepesertaan serta data anggota keluarga yang juga merupakan peserta BPJS, memudahkan pembayaran iuran, memudahkan akses pada layanan kesehatan, serta memudahkan pengaduan dan permohonan informasi dari sistem JKN-KIS.

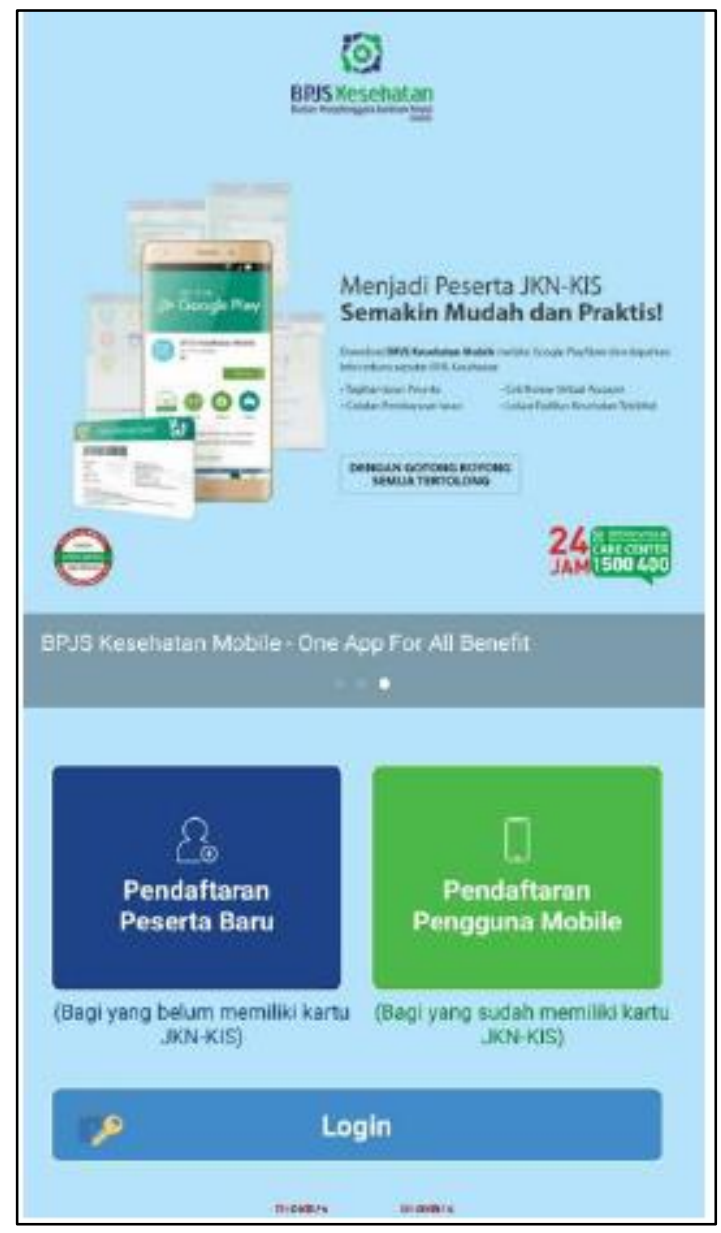

Gambar 21. Laman awal sebelum registrasi aplikasi. Pada laman ini pengguna dapat memilih untuk mendaftar sebagai peserta BPJS baru atau melakukan registrasi untuk akses data melalui aplikasi.

Untuk memenuhi lima tujuan tersebut, aplikasi Mobile JKN memiliki 14 fitur. Dari 14 fitur ini, beberapa fitur yang relevan sebagai referensi dalam pengembangan sistem E-PHR adalah akses terhadap data pribadi dalam sistem layanan kesehatan (termasuk akses untuk mengubah informasi tersebut), mendeteksi lokasi pengguna dan menampilkan lokasilokasi FKTP yang dekat dengan posisi pengguna secara real time, 
mendaftarkan diri untuk antrean daring pada FKTP yang sudah mengaktifkan fitur tersebut, serta menampilkan riwayat kunjungan ke fasilitas layanan kesehatan.

Setelah mendaftar sebagai anggota BPJS Kesehatan dan melakukan registrasi untuk dapat mengakses data melalui Mobile JKN peserta dapat mengakses fitur-fitur utama dari aplikasi tersebut. Pada laman awal atau homepage pengguna dapat mengakses beberapa pilihan tergantung kepentingan. Pengguna dapat mengakses informasi kepesertaan untuk melihat daftar peserta yang terhubung melalui aplikasi pengguna, mengubah data pribadi dalam sistem, dan mendaftarkan peserta baru. Selain itu, pengguna juga dapat memilih menu-menu lain seperti menu tagihan, pelayanan, dan umum.

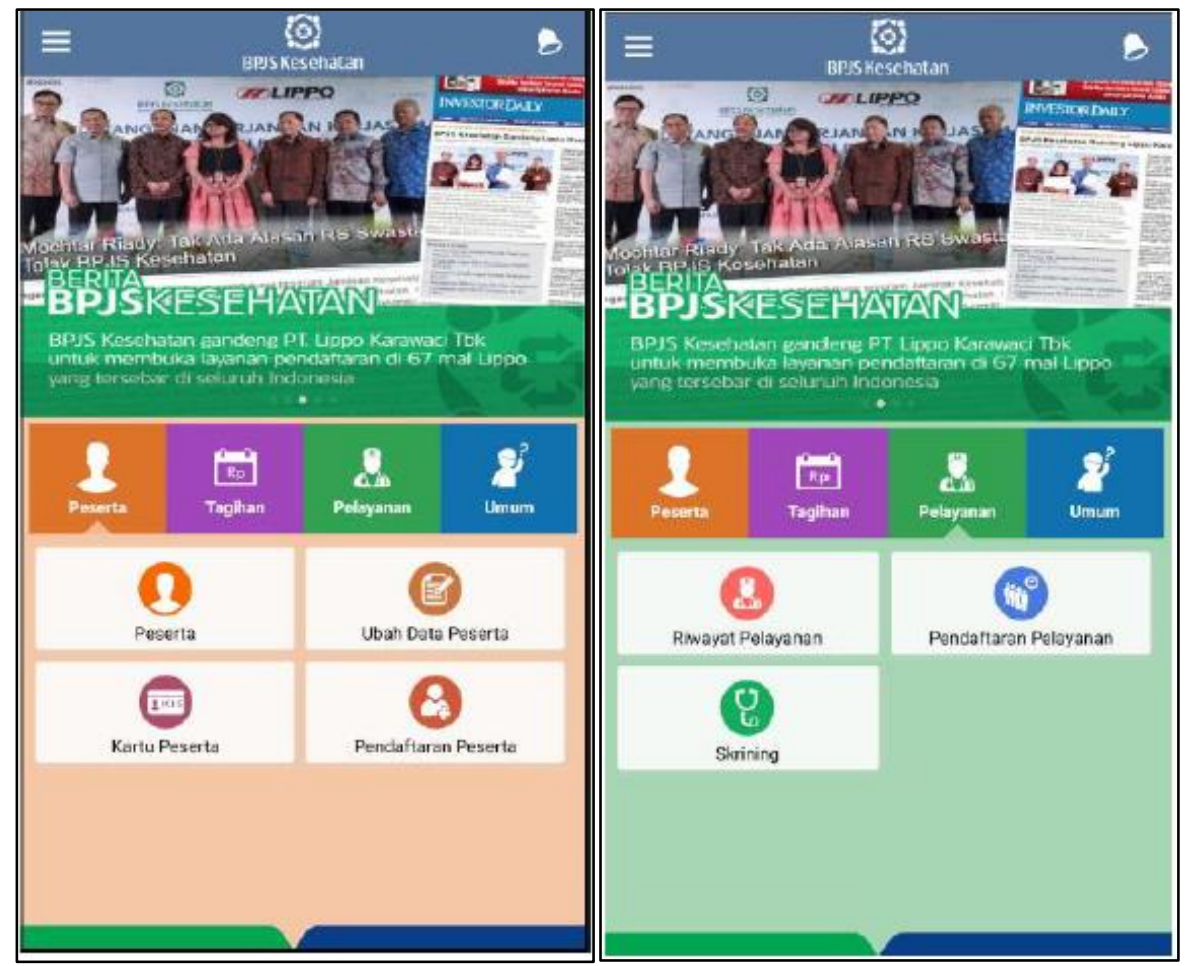

Gambar 22. Tampilan pilihan dalam menu peserta (kiri) dan pelayanan (kanan). Kedua menu ini merupakan fitur-fitur yang sering muncul pada sistem-sistem E-PHR.

Menu pelayanan adalah yang paling relevan dalam pengembangan EPHR karena di dalamnya tersedia fitur pendaftaran pelayanan, riwayat pelayanan, dan skrining. Pada fitur pendaftaran pelayanan pengguna bisa mendaftar antrean di FKTP di mana pengguna terdaftar, akan tetapi 
fungsionalitas fitur ini bergantung pada ketersediaan layanan pendaftaran online di FKTP tersebut. Pada fitur riwayat pelayanan aplikasi akan menampilkan daftar kunjungan-kunjungan pengguna ke fasilitas layanan kesehatan baik FKTP maupun fasilitas layanan kesehatan lanjutan seperti rumah sakit. Daftar kunjungan ini menampilkan informasi terbatas yaitu nama fasilitas layanan kesehatan yang dikunjungi, keluhan pada saat kunjungan, diagnosis, dan terapi yang diberikan. Dalam fitur ini pengguna juga dapat memberikan penilaian atau feedback mengenai kepuasan terhadap layanan yang diberikan dengan memberikan bintang dari skala 1 sampai 5.

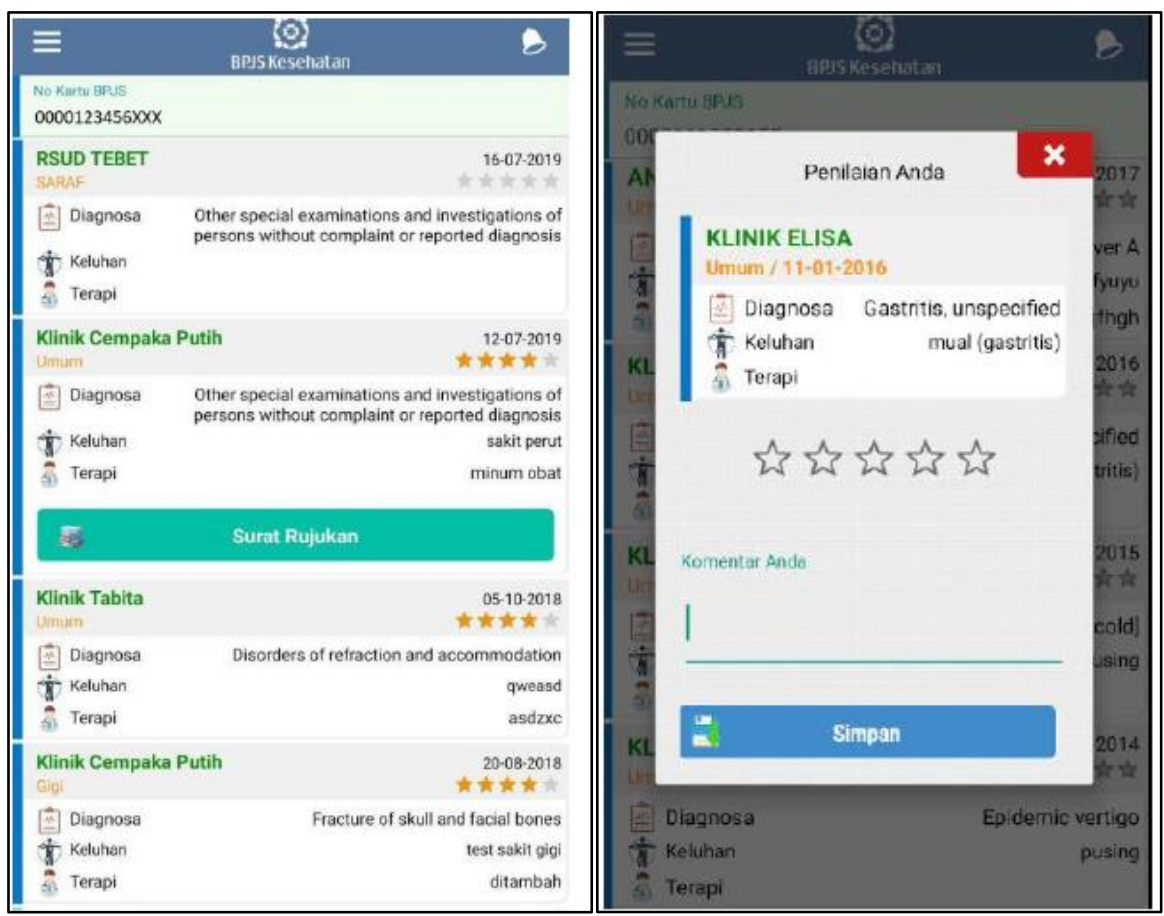

Gambar 23. Tampilan fitur riwayat pelayanan (kiri) dan review layanan (kanan). 


\section{Krama Bali Sehat}

Tabel 12. Kekuatan dan kelemahan Krama Bali Sehat

\begin{tabular}{ll} 
Kekuatan & Kelemahan \\
\hline $\begin{array}{ll}\text { - Dikembangkan dan diselenggarakan } \\
\text { oleh Dinas Kesehatan Provinsi Bali }\end{array}$ & - Tidak direnacanakan memiliki fitur \\
sehingga memiliki kekuatan untuk & rekam medis ataupun rekam \\
meningkatkan penggunaan system & kesehatan sehingga mengurangi \\
oleh tenaga kesehatan maupun & manajemen kesehatan pribadi yang \\
masyarakat. & merupakan visi E-PHR. \\
& - Masih dalam tahap pengembangan \\
& sehingga penilaian penggunaan, \\
& manfaat, dan kendala masih belum \\
& dapat dievaluasi sepenuhnya.
\end{tabular}

Seperti diketahui, Pemerintah Provinsi Bali di bawah Gubernur I Wayan Koster sedang mengembangkan sistem informasi kesehatan bertajuk Krama Bali Sehat (KBS Bali). Latar belakang pengembangan sistem ini adalah untuk mengintegrasikan sistem-sistem informasi kesehatan yang saat ini terfragmentasi dan menyajikan data terkait layanan kesehatan pada masyarakat sebagai penerima manfaat layanan tersebut.

Saat ini KBS Bali masih dalam tahap pengembangan dan ditargetkan akan diluncurkan pada bulan Desember 2019. Dalam proses pengembangan ini rancangan desain KBS Bali telah mengalami perubahan dan penyesuaian dari desain awal. Desain awal KBS Bali mencanangkan dua titik akses dan sistem antarmuka yang berjalan paralel. Titik akses pertama adalah sistem berbasis laman web dengan aplikasi smartphone yang dikembangkan paralel.

Dalam desain awal KBS Bali, pengguna dapat mendaftar dengan pendaftaran berbasis nomor induk kependudukan (NIK). Pengguna terverifikasi akan dapat mengakses fitur-fitur riwayat kesehatan pribadi (riwayat kunjungan, keluhan, diagnosis, dan terapi). Dalam hal ini, fitur-fitur KBS Bali memenuhi kriteria sistem E-PHR. Selain itu, pengguna juga dapat mengakses informasi kesehatan yang meliputi informasi fasilitas kesehatan yang tersedia (puskesmas/klinik swasta/rumah sakit, dengan sarana dan prasarana layanan yang tersedia di masing-masing layanan), informasi 
daftar penyakit-penyakit tersering, ketersediaan ambulans, serta informasi kesehatan tradisional. Selain itu pengguna juga dapat menyampaikan keluhan mengenai sistem Jaminan Kesehatan Nasional melalui sistem KBS Bali. Dalam hal pelayanan, KBS Bali memiliki fitur pendaftaran dan antrian online untuk memperoleh layanan kesehatan di puskesmas dan rumah sakit. Informasi dan fitur-fitur ini dapat diakses melalui laman web KBS Bali ataupun aplikasi smartphone.

Tabel 13. Fitur-fitur dalam Krama Bali Sehat Provinsi Bali

\section{Rancangan Awal}

- Pendaftaran antrean online

- Puskesmas

- Rumah sakit

- Riwayat kesehatan

- Riwayat kunjungan

- Riwayat keluhan

- Riwayat diagnosis

- Riwayat terapi

- Informasi fasilitas kesehatan (puskesmas/klinik/rumah sakit)

- Akreditasi

- Sarana/prasarana

- Tenaga kesehatan

- Informasi statistik

- 10 besar penyakit

- Status gizi

- Ideks Keluarga Sehat

- dll.

- Informasi ketersediaan ambulans

- Penyampaian keluhan JKN

\section{Rancangan Akhir (per 13 Juli 2019)}

- Pendaftaran antrean online

- Puskesmas

- Rumah sakit

- Informasi fasilitas layanan kesehatan

(puskesmas/klinik/rumah sakit)

- Akreditasi

- Sarana/prasarana

- Tenaga kesehatan

- Informasi statistik

- 10 besar penyakit

- Status gizi

- Ideks Keluarga Sehat

- dll.

- Penyampaian keluhan JKN

Setelah pembahasan dengan pihak-pihak yang terkait dalam pengembangan sistem KBS Bali, dilakukan beberapa perubahan mengenai fitur-fitur yang akan dikembangkan dalam sistem KBS Bali. Salah satu fitur utama yang dihilangkan adalah fitur riwayat kesehatan pribadi sehingga rancangan desain KBS Bali terakhir tidak menampilkan informasi riwayat keluhan, diagnosis, serta perawatan pribadi. Dengan dihilangkannya fitur 
tersebut, KBS Bali kehilangan ciri E-PHR dan berubah menjadi sistem informasi kesehatan dalam rangka layanan public. Per tanggal 18 Juli 2019, fitur-fitur yang dicanangkan dalam sistem KBS Bali meliputi informasi kesehatan yang meliputi informasi fasilitas kesehatan yang tersedia (puskesmas/klinik swasta/rumah sakit, dengan sarana dan prasarana layanan yang tersedia di masing-masing layanan), informasi daftar penyakit-penyakit tersering, ketersediaan ambulans, serta informasi kesehatan tradisional. Fitur informasi ketersediaan ambulans juga ditunda dan direncanakan untuk ditambahkan pada 2020.

\section{Nilai tambah yang diinginkan dari E-PHR}

Berdasarkan kajian di atas, maka dapat dirumuskan apa saja fitur dan manfaat yang didapat dari system yang sudah berjalan saat ini dan apa saja manfaat-manfaat yang diharapkan dapat diperoleh sebagai nilai tambah dari pengembangan system E-PHR yang baru. Nilai tambah ini dapat dapat dibagi menjadi 4 komponen yaitu: pengambilan kebijakan publik, optimasi program preventif dan promotive, manfaat dalam pelayanan kesehatan kuratif, serta pengembangan dan inovasi demi layanan kesehatan yang lebih efisien. Penjabaran masing-masing komponen nilai tambah akan dijabarkan sebagai berikut.

\section{Manfaat dalam pengambilan kebijakan publik}

Sistem-sistem yang sudah berjalan saat ini masih bersifat tersegmentasi dengan integrasi terbatas antara komponen-komponen pemangku kepentingan dan pengambil kebijakan dalam system layanan kesehatan di Kabupaten Badung. Hal ini dapat terlihat dari sistem-sistem yang sudah berjalan yang masing-masing hanya tersedia untuk salah satu pemangku kepentingan, misalnya P-Care hanya tersedia bagi FKTP mitra BPJS, e-Puskesmas hanya tersedia bagi puskesmas, V-Claim hanya tersedia bagi rumah sakit mitra BPJS, dan seterusnya.

Dengan adanya segmentasi system-sistem informasi yang digunakan saat ini, tidak terdapat akses langsung dari fasilitas-fasilitas layanan kesehatan, baik tingkat pertama maupun rujukan, ke Dinas Kesehatan Kabupaten Badung sebagai pengambil kebijakan dalam bidang kesehatan di wilayah Kabupaten Badung. Seperti diketahui, akses informasi seperti ini 
bersifat penting bagi pihak pengambil kebijakan karena pengambilan dan evaluasi kebijakan harus dilakukan berdasarkan data yang dapat diandalkan.

Saat ini informasi-informasi yang dibutuhkan Dinas Kesehatan sebagai pemangku kebijakan masih diambil secara manual melalui laporanlaporan berkala dari fasilitas layanan kesehatan. Beberapa sistem informasi yang berjalan saat ini sudah mempermudah pembuatan laporan ini, misalnya e-Puskesmas yang memiliki fitur rekapitulasi 10 besar penyakit bulanan secara otomatis. Akan tetapi, kami melihat adanya peluang untuk perbaikan dan penyempurnaan system pelaporan ini dengan pengembangan system E-PHR.

Pengembangan system E-PHR yang akan digunakan secara universal oleh semua fasilitas layanan kesehatan, baik tingkat pertama maupun rujukan, baik mitra BPJS maupun bukan, dapat menjadi alat pengumpulan data yang optimal bagi Dinas Kesehatan sebagai pemangku kebijakan. Pelaporan ini dapat difasilitas dengan pengembangan fitur dashboard atau User Interface khusus bagi Dinas Kesehatan di mana petugas di Dinas Kesehatan dapat menarik data agregat mengenai angka kejadian, prevalensi, dan sebaran penyakit dari fasilitas-fasilitas layanan kesehatan secara real time sehingga memangkas proses penyusunan laporan berkala yang selama ini menjadi sumber data. Selain itu, system E-PHR yang juga digunakan oleh fasilitas kesehatan swasta dan fasilitas kesehatan non-mitra BPJS juga dapat menjaring informasi yang selama ini mungkin tidak terserap melalui system informasi yang ada.

\section{Optimasi program preventif dan promotif}

Pengembangan sistem informasi kesehatan idealnya mengakomodasi kebutuhan dari layanan, tidak hanya untuk upaya pengobatan (kuratif) tetapi juga untuk upaya pencegahan (promotif dan preventif). Jika melihat sistem yang sudah ada di Kabupaten Badung saat ini, sebagian besar masih cenderung mengutamakan pada upaya pengobatan yang berfokus pada pasien secara perseorangan. Padahal, apabila upaya promotif dan preventif lebih diutamakan, maka secara perlahan derajat dari kesehatan masyarakat akan meningkat sehingga dapat mengurangi beban pelayanan maupun pembiayaan di layanan kuratif (fasilitas kesehatan). Di sisi lain, akses terhadap data kesehatan dasar pasien masih belum tersedia 
dengan baik sehingga pasien belum bisa secara mandiri mengelola status kesehatannya. Rendahnya akses data kesehatan perseorangan ini menyebabkan masyarakat tidak tahu risiko penyakit yang dideritanya sehingga cenderung berobat/mengakses layanan apabila sudah benarbenar sakit. Berdasarkan hal tersebut, maka pengembangan E-PHR diharapkan mampu menyediakan data kesehatan dasar yang terintergasi antara fasilitas kesehatan serta dapat diakses oleh pasien secara mandiri sehingga pasien dapat secara aktif turut serta dalam upaya promotif dan preventif agar terhindar dari kesakitan.

Sehubungan dengan hal tersebut, dalam pengembangan E-PHR dapat ditambahkan fitur pengingat atau notifikasi untuk program-program preventif dan promotif. Notifikasi ini dapat digunakan untuk menarik perhatian masyarakat pengguna E-PHR pada informasi-informasi kesehatna penting yang ingin disosialisasikan oleh Dinas Kesehatan Kabupaten Badung. Informasi yang disebarkan melalui system E-PHR memiliki keunggulan mengenai tingkat kepercayaannya: E-PHR merupakan program pemerintah sehingga informasi yang disebarkan melalui system E-PHR dapat dipercaya sebagai informasi yang terverifikasi oleh Dinas Kesehatan Kabupaten Badung sebagai unsur pemerintah. Dalam era di mana disinformasi dan hoax dalam bidang kesehatan sedang marak menyebar, saluran informasi resmi dan terpercaya dari unsur pemerintahan ke masyarakat akan menjadi nilai tambah yang bermanfaat.

Fitur pengingat untuk kegiatan preventif dan promotif dapat ditambahkan dalam E-PHR, dengan harapan informasi mengenai pelaksanaan program kesehatan, seperti misalnya: posyandu dapat tersampaikan kepada seluruh masyarakat setempat. Notifikasi pada fitur pengingat sebaiknya bersifat "selektif notifikasi" yang berarti notifikasi tersebut hanya diperuntukan bagi masyarakat yang termasuk sasaran atau target dari program tersebut. Fitur ini diharapkan menjadi nilai tambah yang meningkatkan kepesertaan masyarakat dalam program-program promotif dan preventif sehingga meningkatkan capaian dan keberhasilan program tersebut.

\section{Manfaat dalam pelayanan kesehatan kuratif}

Pengembangan system E-PHR diharapkan dapat menjawab beberapa kendala dan kekurangan dari sistem informasi layanan kesehatan 
yang berlaku saat ini. Salah satu masalah yang dapat dijawab adalah kendala kurangnya komunikasi antara fasiltias-fasilitas layanan kesehatan. Harus disadari bahwa banyak pasien yang dihadapi di fasilitas layanan kesehatan memiliki literasi kesehatan yang rendah. Akibatnya, informasi yang dapat dipercaya mengenai riwayat kesehatan, riwayat penyakit, riwayat pengobatan, dan riwayat alergi sulit didapat.

Sistem E-PHR dapat menjawab kendala ini. E-PHR yang digunakan secara universal oleh semua fasilitas layanan kesehatan dapat mengoptimalkan komunikasi informasi riwayat kesehatan pasien antar fasiitas layanan kesehatan. E-PHR ibaratnya menggabungkan sistem informasi dan rekam kesehatan dari semua fasilitas layanan kesehatan yang menjadi pengguna. Dengan demikian, informasi riwayat kesehatan pasien yang tercatat di salah satu fasilitas layanan kesehatan dapat diakses ketika pasien tersebut kemudian berobat di fasilitas layanan kesehatan lain yang juga terhubung dengan sistem E-PHR. Hal ini mengoptimalkan komunikasi mengenai informasi riwayat kesehatan pasien sehingga petugas kesehatan dapat memberikan layanan kesehatan yang lebih optimal.

\section{Inovasi layanan kesehatan yang efisien}

Berdasarkan kajian dapat juga dirumuskan beberapa fitur yang diharapkan muncul dalam E-PHR untuk meningkatkan efisiensi layanan kesehatan. Peningkatan efisiensi ini dapat dicapai dengan pemberdayaan individual pengguna untuk melakukan manajemen kesehatan pribadi yang lebih efektif serta mengurangi penggunaan layanan kesehatan yang tidak diperlukan.

Manajemen kesehatan pribadi yang efektif diharapkan dapat dicapai dengan integrasi beberapa fitur dalam E-PHR seperti fitur pengingat minum obat, pengingat jadwal kontrol, informasi factor risiko dan gaya hidup sehat, serta radar wabah. Masing-masing fitur ini dapat membantu pengguna EPHR untuk mengatur gaya hidup sehingga dapat menghindari factor risiko serta mencegah penyakit, baik penyakit menular, melalui radar wabah, ataupun penyakit tidak menular, melalui pengingat gaya hidup sehat. Bagi pengguna yang sudah terlanjur menderita penyakit kronis, pengingat minum obat dan kontrol dokter dapat membantu pengguna mengendalikan penyakit kronisnya. Secara kolektif, pencegahan insidensi penyakit serta 
pengendalian penyakit kronis ini membantu mengurangi penggunaan layanan kesehatan kuratif yang dapat dicegah.

Kontrol penggunaan layanan kesehatan kuratif juga dapat dicapai dengan penerapan fitur live chat atau telemedicine dalam sistem E-PHR. Live chat atau telemedicine menghubungkan pengguna E-PHR yang awam masalah kesehatan dengan dokter untuk melakukan konsultasi melalui sarana telekomunikasi. Konsultasi yang dilakukan sebelum kunjungan ke layanan kesehatan dapat menjadi sawar atau titik seleksi untuk masalahmasalah kesehatan yang dipresentasikan pasien atau pengguna. Dengan fitur ini, diharapkan masalah-masalah kesehatan yang kurang serius dan tidak memerlukan penanganan petugas kesehatan professional dapat ditangani secara telemedicine sehingga mengurangi beban di fasilitas layanan kesehatan. Akibatnya, sumber daya di fasiltias layanan kesehatan dapat dioptimalkan untuk menangani pasien-pasien yang benar-benar menderita masalah kesehatan yang serius.

\section{Apakah E-PHR dapat terus dikembangkan sesuai kebutuhan?}

Pengembangan suatu sistem informasi kesehatan bukanlah proses sekali jadi, tetapi akan terus berkembang seiring dengan kebutuhan layanan serta perkembangan teknologi informasi yang ada. Apabila E-PHR di Kabupaten Badung ingin serius untuk dikembangkan, maka proses pengembangannya hendaknya memerhatikan kebutuhan layanan di masa yang akan datang serta potensi integrasi dengan berbagai jenis teknologi yang berkembang di masa depan. Hal ini sangat penting untuk menciptakan sistem E-PHR yang berkesinambungan. Salah satu contoh pesatnya perkembangan teknologi informasi yang perlu diperhatikan dalam pengembangan sistem E-PHR adalah terkait dengan metode akses data. Saat ini, akses data kesehatan pasien atau peserta KBS yang tercatat dalam layanan kesehatan dapat dilakukan melalui scan QR code maupun memasukkan secara manual untuk nomor JKN/KIS. Ke depan metode ini dapat berkembang menjadi akses melalui biometric, seperti melalui sidik jari, retina, maupun teknologi akses lainnya. Selain itu, potensi pengembangan E-PHR juga dapat mempertimbangkan perkembangan teknologi medis. Saat ini pemeriksaan kesehatan cenderung dilakukan di layanan kesehatan. Sedangkan ke depan pemeriksaan kesehatan dapat dilakukan secara mendiri oleh pasien melalui perangkat smartwatch atau 
teknologi lain. Hal ini menunjukkan pengembangan E-PHR juga hendaknya melihat potensi ini agar tidak tertinggal dengan perkembangan zaman.

\section{Kelayakan Pasar (Market feasibility)}

Analisis terhadap Market feasibility atau kelayakan pasar dilihat dari aspek pengguna sistem E-PHR yang akan dikembangkan di Kabupaten Badung. Dalam hal ini, pengguna sistem E-PHR tediri dari Dinas Kesehatan, penyedia layanan kesehatan, dan masyarakat atau peserta KBS.

\section{Dinas Kesehatan}

Pengembangan sistem E-PHR untuk meningkatkan pelayanan kesehatan di Kabupaten Badung akan memberikan maanfaat bagi Dinas Kesehatan selaku leading sector bidang kesehatan di Kabupaten Badung. Informasi untuk pengambilan keputusan serta pembuatan kebijakan sangat penting diperoleh oleh Dinas Kesehatan agar bisa menyediakan pelayanan kesehatan yang efektif dan efisien bagi masyarakat. Oleh sebab itu, pengembangan sistem E-PHR hendaknya dilakukan sesuai dengan kebutuhan Dinas Kesehatan.

Jika dilihat dari ketersediaan sumber daya manusia yang saat ini dimiliki oleh Dinas Kesehatan, pengembangan sistem E-PHR tidak dapat diserahkan sepenuhnya kepada Dinas Kesehatan. Hal ini dikarenakan sumber daya manusia yang dimiliki saat ini belum memiliki kompetensi dan keahlian sebagai pengembang sebuah sistem informasi kesehatan. Sumber daya manusia yang dimiliki oleh Dinas Kesehatan sejauh ini hanya untuk pelayanan kesehatan serta penyelenggara program kesehatan. Oleh sebab itu, pengembangan sistem E-PHR sebaiknya diserahkan pada pihak yang memang memiliki kompetensi serta keahlian sebagai developer sistem informasi kesehatan. Pihak developer yang dimaksud dapat melalui Organisasi Perangkat Daerah (OPD) seperti Dinas Komunikasi dan Informasi, maupun dapat melalui pihak ketiga di luar OPD. Sebagai leading sector, Dinas kesehatan dapat melakukan kerjasama dengan pihak developer tersebut mulai dari proses pengembangan sistem E-PHR hingga pemeliharaan. 


\section{Penyedia Layanan Kesehatan}

Pihak yang dimaksud sebagai penyedia layanan kesehatan adalah fasilitas kesehatan, mulai dari FKTP hingga FKRTL. Pengembangan sistem E-PHR hendaknya mempertimbangkan kebutuhan dari penyedia layanan kesehatan serta disesuaikan dengan jenis layanan. Hal ini dikarenakan sistem E-PHR di layanan FKTP tentu berbeda dengan di layanan FKRTL. Pengembangan E-PHR juga hendaknya disesuaikan dengan kebutuhan apakah sistem ini akan digunakan di fasilitas kesehatan atau pada dokter praktik mandiri. Pertimbangan ini sangat penting untuk dilakukan agar sistem E-PHR yang dikembangkan memberikan manfaat tidak hanya pemberi layanan di fasilitas kesehatan, tetapi juga pemberi layanan di dokter praktik mandiri.

Jika dilihat dari proses pelayanan kesehatan yang sudah berlangsung hingga saat ini, penyedia layanan kesehatan sudah memiliki sumber daya manusia yang kompeten dalam menggunakan sistem informasi kesehatan. Pada layanan FKTP, petugas kesehatan sudah terbiasa menggunakan ePuskesmas maupun P-Care. Sedangkan pada layanan FKRTL, petugas layanan sudah terbiasa menggunakan V-Claim. Proses yang sama juga ditemukan pada dokter praktik mandiri (dokter umum dan dokter gigi) yang sudah terbiasa menggunakan P-Care. Kondisi ini menunjukkan bahwa apabila sistem E-PHR dikembangkan, maka penyedia layanan kesehatan akan siap dalam menerapkan E-PHR.

Meskipun sumber daya manusia yang dimiliki oleh penyedia layanan kesehatan sudah siap menerapkan E-PHR, terdapat beberapa hal yang perlu menjadi pertimbangan dalam pengembangan E-PHR. Jika berkaca dari penerapan sistem informasi yang sudah ada (ePuskesmas, P-Care, dan VClaim), masih terdapat kendala yang dihadapi oleh petugas kesehatan di layanan. Kendala yang dihadapi sebagian besar adalah kendala teknis, seperti sering terjadinya eror pada bridging system sehingga memaksa petugas kesehatan di layanan untuk melakukan multiple input karena terdapat banyak sistem informasi yang digunakan dalam satu layanan. Kondisi ini menyebabkan pelayanan kesehatan menjadi tidak efektif dan efisien. Oleh sebab itu, maka pengembangan E-PHR hendaknya dapat memberikan kemudahan dan kenyamanan bagi petugas kesehatan sehingga mendorong terjadinya efisiensi dalam bekerja/memberikan pelayanan 
kesehatan. Hal ini sangat penting agar sistem E-PHR yang dikembangkan dapat terus digunakan secara berkesinambungan untuk memberikan pelayanan kesehatan bagi masyarakat.

\section{Masyarakat/Peserta KBS}

Pengembangan suatu sistem informasi kesehatan hendaknya tidak hanya berfokus pada kebutuhan dari pemangku kebijakan serta penyedia layanan kesehatan, tetapi juga pada masyarakat yang mengakses layanan. Jika melihat tren saat ini di masyarakat, perkembangan teknologi informasi yang sangat pesat juga berpengaruh terhadap pola mengakses layanan kesehatan. Saat ini, masyarakat sudah mampu secara aktif untuk memperoleh informasi seputar kesehatan di internet melalui perangkat smartphone yang dimiliki. Selain itu, masyarakat saat ini juga cenderung memiliki keinginan serba praktis, termasuk dalam mengakses pelayanan kesehatan. Perkembangan teknologi informasi ini berdampak pada timbulnya tuntutan masyarakat kepada penyedia layanan kesehatan agar bisa menciptakan pelayanan yang cepat, efektif, dan efisien. Berdasarkan hal tersebut, maka pengembangan sistem E-PHR juga hendaknya mengakomodasi kebutuhan masyarakat. Hal ini dikarenakan agar sistem EPHR juga dapat digunakan secara berkesinambungan oleh masyarakat serta dapat memberikan banyak manfaat untuk meningkatkan kualitas kesehatan masyarakat.

Jika dilihat lebih jauh terkait karakteristik sosiodemografi masyarakat di Kabupaten Badung, sebagian besar sudah melek teknologi serta memiliki akses internet. Saat ini, smartphone sudah menjadi kebutuhan dasar sebagian besar masyarakat. Setidaknya dalam satu kepala keluarga sudah terdapat smartphone. Jika ditinjau dari akses internet, selain internet yang dimiliki secara perseorangan melalui perangkat smartphone yang dimiliki, pemerintah juga sudah menyediakan akses internet secara gratis hingga di tingkat banjar. Hal tersebut menunjukkan bahwa apabila EPHR dikembangkan, maka sebagian besar masyarakat Kabupaten Badung sudah siap.

Meskipun demikian, pengembangan sistem E-PHR juga perlu memerhatikan masyarakat yang belum mampu memiliki maupun tidak bisa menggunakan smartphone. Beberapa kelompok masyarakat yang dimaksud 
adalah masyarakat dari golongan ekonomi menengah ke bawah serta lansia. Oleh sebab itu, pengembangan sistem E-PHR hendaknya mengakomodasi semua lapisan masyarakat agar adanya asas keadilan bagi semua masyarakat Badung. Salah satu alternatifnya adalah dengan mengembangakan suatu aplikasi berbasis smartphone berbasiskan keluarga, sehingga sistem E-PHR yang dikembangkan dapat menjangkau seluruh masyarakat Badung. Berdasarkan hasil wawancara, diperoleh hasil bahwa sejauh ini rencana pengembangan dan implementasi E-PHR mendapat dukungan positif dari masyarakat di Kabupaten Badung. Namun, ada satu hal penting yang perlu dilakukan oleh pemerintah jika E-PHR sudah memasuki tahap implementasi hendaknya pemerintah melakukan sosialisasi dan demo penggunaan aplikasi E-PHR baik secara langsung, maupun melalui media massa.

\section{Kelayakan Pembiayaan (Financial feasibility)}

\section{Ketersediaan Sumber Dana}

Jaminan akan tersedianya dana menjadi hal yang penting jika pemerintah Kabupaten Badung ingin mengembangkan dan mengimplementasikan E-PHR. Dalam pengembangan dan implementasinya tentu saja tidak menghabiskan dana yang sedikit. Untuk mendukung terciptanya proses pengembangan dan pelaksanaan yang optimal dan berkelanjutan, maka pemerintah perlu menyiapkan anggaran untuk proses tersebut. Berdasarkan hasil wawancara dengan salah satu pihak Dinas Kesehatan, jika dilihat dari kesiapan dana bahwa Pemerintah Kabupaten Badung memiliki komitmen yang tinggi dan mengalokasikan dana yang cukup benar untuk pengembangan E-PHR ini. 


\section{Budgeting Pengembangan dan Pemeliharaan E-PHR}

Tabel 14. Perhitungan biaya untuk pengembangan sistem E-PHR

\begin{tabular}{|c|c|c|}
\hline $\begin{array}{c}\text { Development Sistem E-PHR } \\
\text { (KBS Mobile dan KBS Vision) }\end{array}$ & Total & $\mathbf{1 . 4 0 0 . 0 0 0 . 0 0 0}$ \\
\hline
\end{tabular}

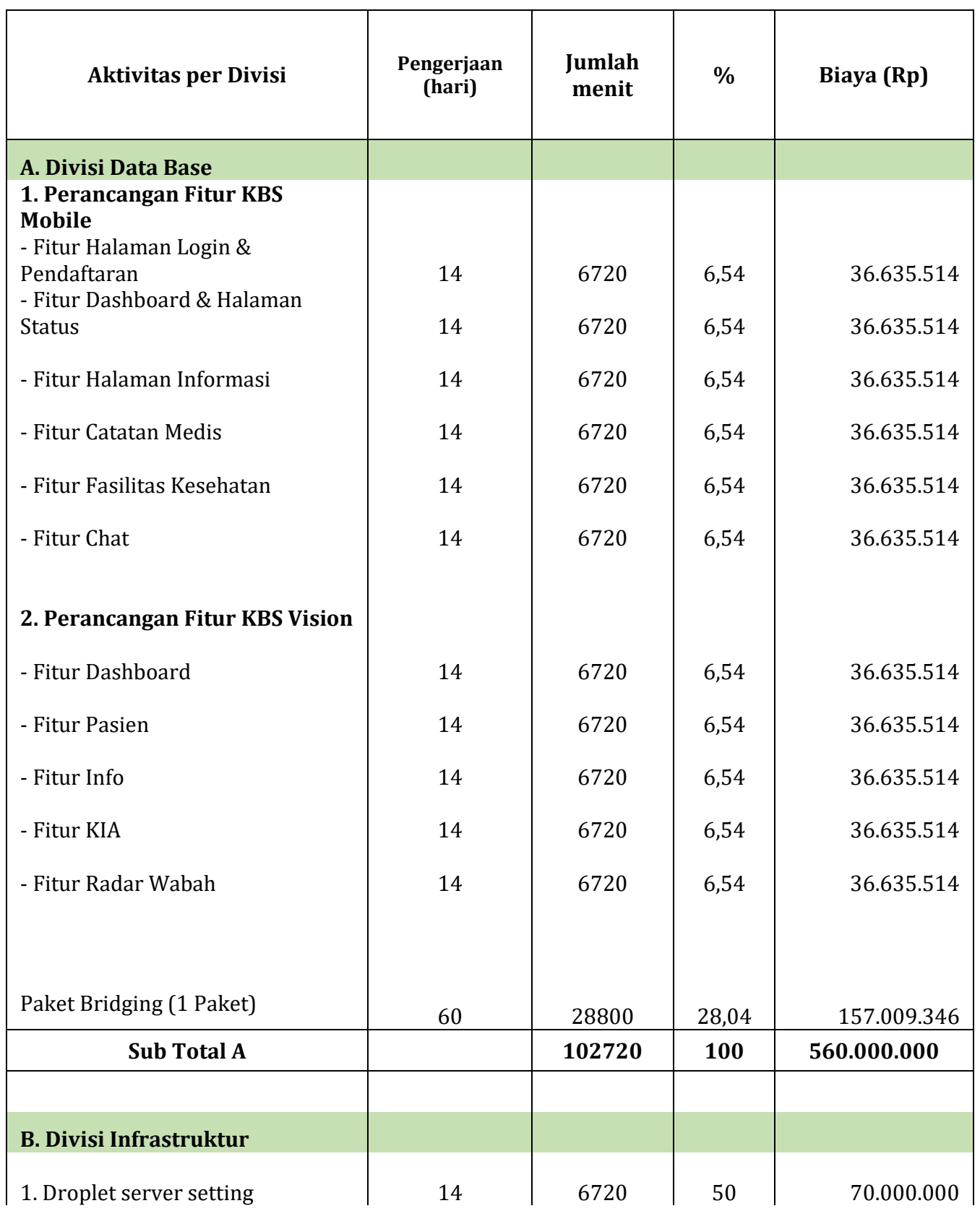




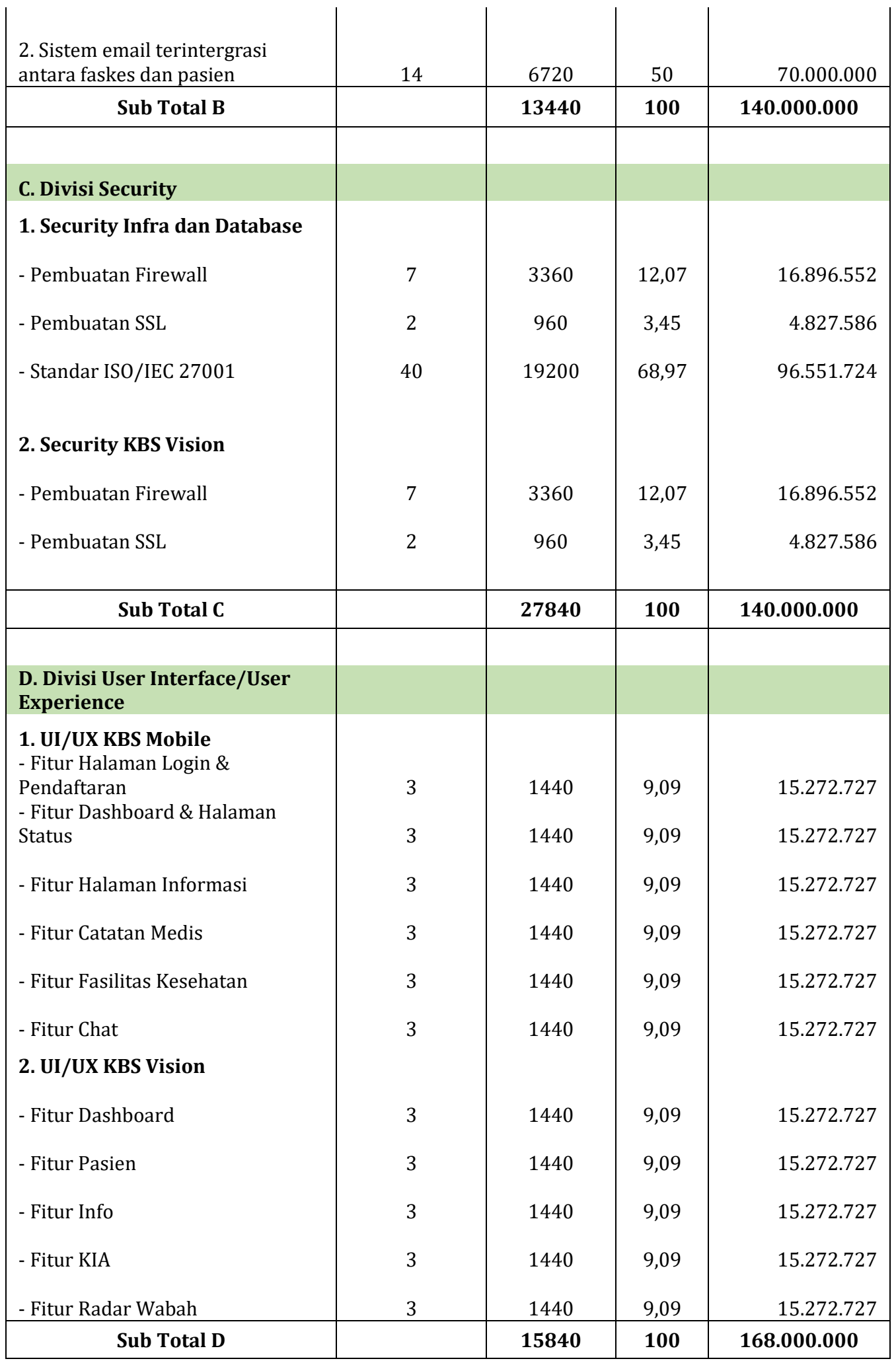




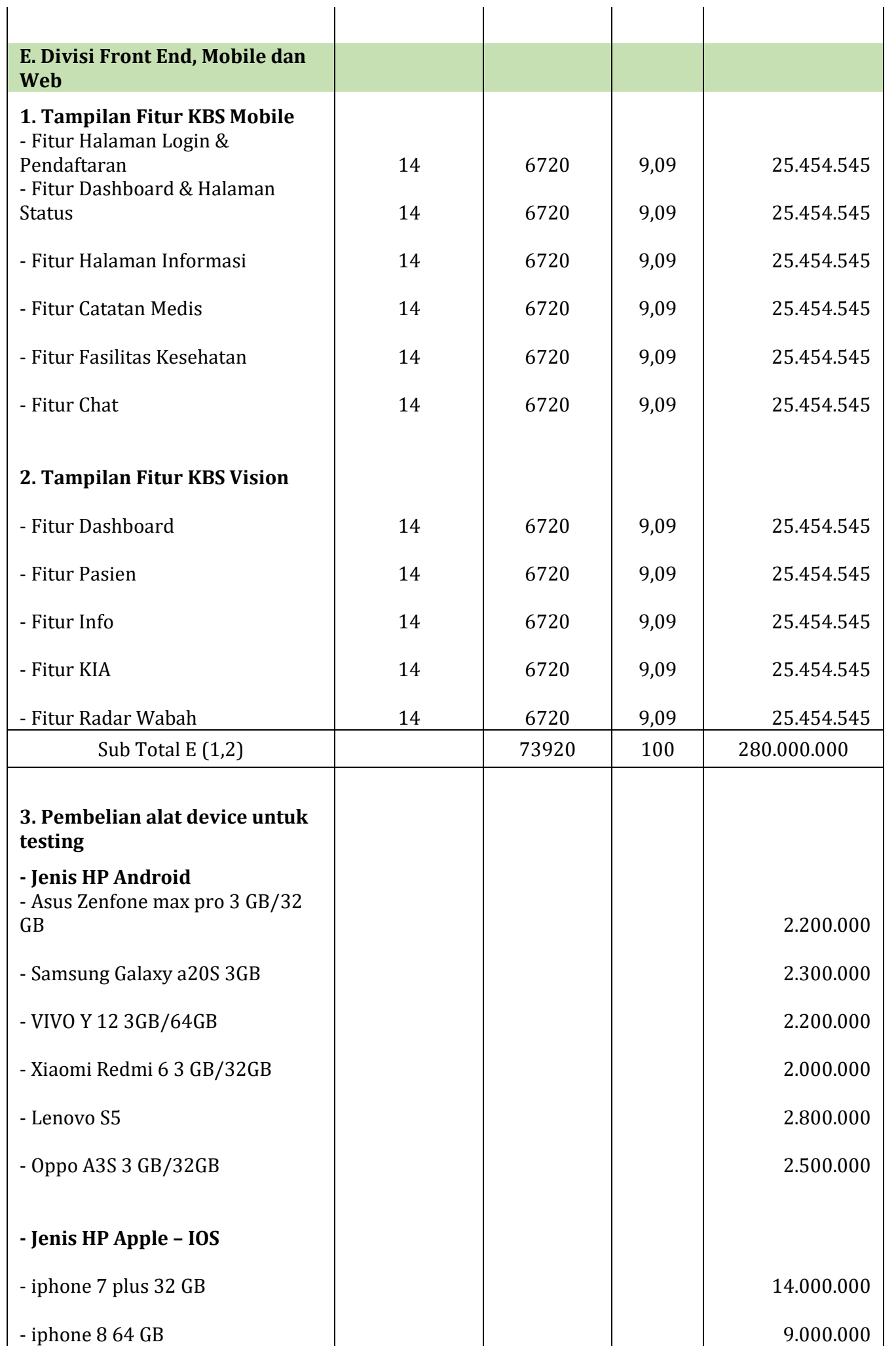




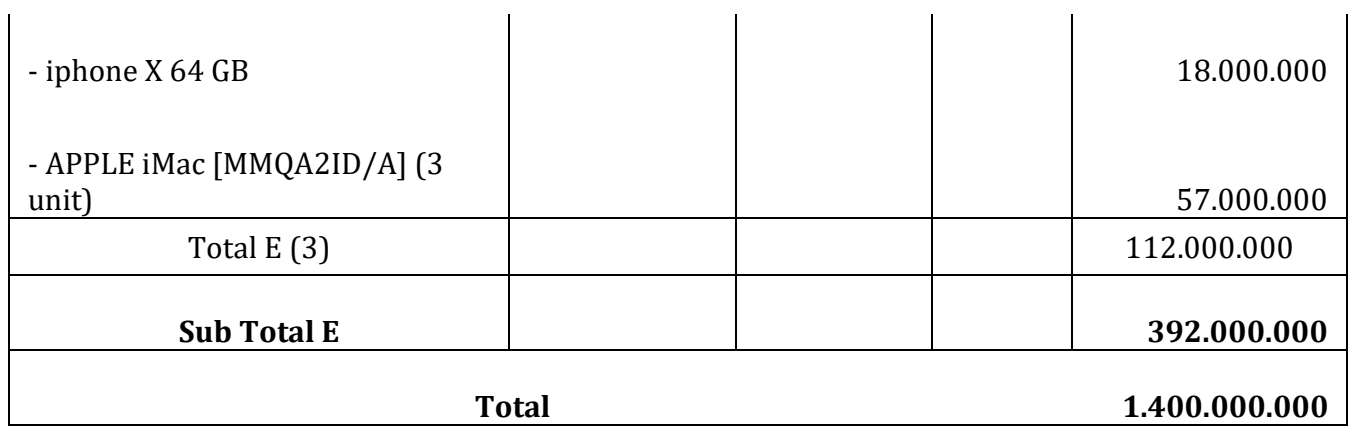

Tabel 15. Budgeting Maintanace Sistem E-PHR

\begin{tabular}{|l|l|l|}
\hline Maintanance (1 Tahun) & Total & $\mathbf{6 0 0 . 0 0 0 . 0 0 0}$ \\
\hline
\end{tabular}

\begin{tabular}{|c|c|c|c|}
\hline Aktivitas & $\%$ & Durasi & Biaya (Rp) \\
\hline A. Testing & $25 \%$ & 3 bulan & 150.000 .000 \\
\hline B. Bug Fix & $30 \%$ & 1 tahun & 180.000 .000 \\
\hline $\begin{array}{l}\text { C. Adjustment (Riset } \\
\text { dan Pengembangan) }\end{array}$ & $20 \%$ & 1 tahun & 120.000 .000 \\
\hline $\begin{array}{l}\text { D. Maintanance server, } \\
\text { bridging dan lain - lain }\end{array}$ & $25 \%$ & 1 tahun & 150.000 .000 \\
\hline \multicolumn{3}{|c|}{ Total } & 600.000 .000 \\
\hline
\end{tabular}

Tabel 16. Budgeting Operasional Sistem E-PHR

\begin{tabular}{|l|c|c|}
\hline $\begin{array}{l}\text { Operasional Server, SDK \& OTP per } \\
\text { Tahun }\end{array}$ & Total & $\mathbf{3 0 0 . 0 0 0 . 0 0 0}$ \\
\hline
\end{tabular}

\begin{tabular}{|l|c|l|r|}
\hline \multicolumn{1}{|c|}{ Aktivitas } & $\%$ & $\begin{array}{c}\text { Waktu } \\
\text { Penggunaa } \\
\text { n }\end{array}$ & \multicolumn{1}{c|}{ Biaya (Rp) } \\
\hline A. Google Cloud Server & $40 \%$ & 1 tahun & 120.000 .000 \\
B. SDK Send Bird & $30 \%$ & 1 tahun & 90.000 .000
\end{tabular}




\begin{tabular}{|lr|r|l|r|} 
C. OTP & & $20 \%$ & 1 tahun & 60.000 .000 \\
D. Google Maps Services & & $10 \%$ & 1 tahun & 30.000 .000 \\
\hline \multicolumn{2}{|c|}{ Total } & $\mathbf{3 0 0 . 0 0 0 . 0 0 0}$ \\
\hline
\end{tabular}

Tabel 17. Prediksi Total Kebutuhan Biaya untuk Sistem E-PHR

\begin{tabular}{|l|r|}
\hline \multicolumn{1}{|c|}{ Rincian } & \multicolumn{1}{c|}{ Biaya (Rp) } \\
\hline Development Sistem EPHR (KBS Mobile dan KBS Vision) & 1.400 .000 .000 \\
Maintenance dan improvement (1 Tahun) & 600.000 .000 \\
Operasional Server, SDK, \& OTP per Tahun & 300.000 .000 \\
\hline \multicolumn{1}{|c|}{ Total (Rp) } & $\mathbf{2 . 3 0 0 . 0 0 0 . 0 0 0}$ \\
\hline
\end{tabular}




\section{Rekomendasi model}

Rekomendasi terhadap sistem informasi yang sudah ada saat ini

Sistem informasi layanan kesehatan saat ini masih terkendala tidak adanya hubungan atau bridging yang stabil antara komponen-komponen terkait di dalamnya. Sistem informasi yang dikembangkan BPJS, seperti PCare, VClaim, dan Mobile JKN berhasil mempertahankan komunikasi antarsistem yang baik karena dikembangkan secara simultan oleh pengembang yang sama yaitu BPJS sendiri. Gangguan bridging terutama terjadi antara system informasi BPJS dan system informasi yang dikembangkan vendor atau pengembang swasta, seperti e-Puskesmas, yang berusaha dihubungkan dengan PCare.

Untuk mencapai bridging, maka program-program dalam dalam sistem-sistem yang berusaha dihubungkan harus compatible dan bisa berkomunikasi antara satu sama lain. Permasalahan kesulitan bridging PCare dan e-Puskesmas berasal dari update atau patching PCare yang dilakukan secara berkala dalam jangka waktu pendek untuk memenuhi keperluan regulasi internal BPJS dan/atau Kementerian Kesehatan. ePuskesmas yang dikembangkan oleh swasta tidak terlibat dalam penetapan regulasi ini. Selain itu sumberdaya e-Puskesmas yang lebih terbatas dalam melakukan update/patching berujung pada keterlambatan e-Puskesmas dalam mengejar versi PCare terbaru sehingga kadang kali menimbulkan masalah bridging antara kedua sistem tersebut.

Kendala lain yang harus diperhatikan terkait bridging ini adalah ketika E-PHR sudah dikembangkan, system E-PHR harus mampu mempertahankan bridging yang stabil dengan semua system informasi terkait. E-PHR, sebagai system penyajian informasi kesehatan pribadi pada pasien/pengguna, terutama harus mampu mempertahankan bridging dengan system rekam medis atau rekam kesehatan, dalam hal ini berarti ePuskesmas sebagai system manajemen layanan pasien utama di FKTP. Dengan kondisi saat ini, pengembangan E-PHR menimbulkan keharusan bridging yang stabil antara 3 pihak: PCare, e-Puskesmas, dan E-PHR. Menurut pengalaman penggunaan system informasi PCare dan ePuskesmas selama ini, target ini sulit dicapai. 
Hal lain yang harus dipertimbangkan adalah adanya variasi system rekam medis atau rekam kesehatan pada rumah sakit serta klinik swasta. Seperti diketahui, e-Puskesmas hanya digunakan oleh puskesmas. Klinik swasta dan rumah sakit di Kabupaten Badung menggunakan system informasi lain yang bervariasi antara satu fasilitas layanan kesehatan satu dan lainnya. Pengembangan E-PHR akan mengharuskan bridging yang stabil antara semua system rekam kesehatan yang bervariasi ini dengan system EPHR.

Di lain pihak, saat ini sebagian besar layanan, baik puskesmas, FKTP swasta, ataupun rumah sakit, telah menggunakan salah satu system informasi BPJS, baik PCare ataupun VClaim. Akan tetapi, kedua system ini tidak dapat dijadikan sumber data untuk E-PHR. PCare hanya memuat informasi rekam medis yang sangat terbatas sehingga tidak ideal digunakan sebagai rekam medis utama dan sumber data bagi system E-PHR. Hal yang sama dapat dikatakan tentang VClaim yang bahkan memuat lebih sedikit lagi informasi riwayat kesehatan.

Berdasarkan ulasan ini, kami merekomendasikan pengembangan system informasi rekam medis dan riwayat kesehatan yang baru secara simultan dengan pengembangan E-PHR yang akan disajikan. Dalam rekomendasi dan prototipe yang kami siapkan, system rekam medis ini akan dinamai KBS Vision dan system sajian E-PHR yang akan digunakan pengguna disebut KBS Mobile. Sistem rekam medis dan riwayat kesehatan ini diharapkan dapat digunakan oleh semua fasilitas layanan kesehatan, baik puskesmas, klinik swasta, ataupun rumah sakit, menggantikan system rekam medis digital yang saat ini digunakan di masing-masing layanan tersebut. Dengan pengembangan system ini maka e-Puskesmas dan/atau system rekam medis digital lain akan digantikan dengan system rekam medis digital baru yang seragam bagi semua layanan dan terintegrasi dengan system E-PHR. Pengembangan system ini juga akan menyederhanakan upaya bridging karena hubungan yang harus dipertahankan dikurangi menjadi bridging system BPJS (PCare dan VClaim) dengan system E-PHR dan rekam medisnya yang terintegrasi. 


\section{Rancangan Model Sistem E-PHR dalam KBS}

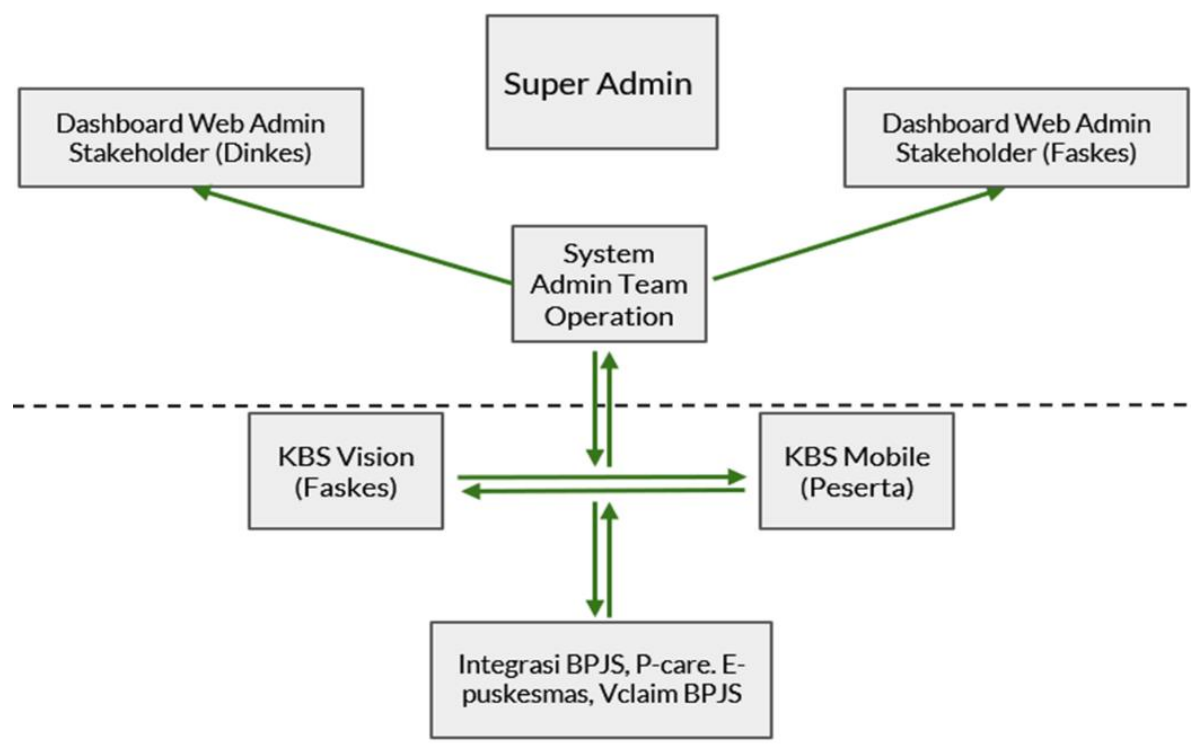

Gambar 24. Rancangan Model Sistem E-PHR dalam KBS

Pengembangan E-PHR di Kabupaten Badung perlu memerhatikan keberadaan sistem yang sudah berjalan saat ini, mulai dari tingkat FKTP hingga FKRTL. Mengacu pada mekanisme penyelenggaraan KBS yang sudah berjalan saat ini, maka secara umum rancangan sistem E-PHR terdiri dari Sistem Admin dan Sistem User Interface. Sistem Admin adalah mekanisme untuk mengelola E-PHR di tingkat pemangku kepentingan (stakeholder), seperti untuk proses perencanaan, monitoring, evaluasi, dan pengambilan keputusan. Sedangkan pada Sistem User Interface adalah mekanisme untuk pengelolaan E-PHR di tingkat pengguna, yaitu pada fasilitas kesehatan pemberi layanan, BPJS, serta pada masyarakat. Pada Sistem User Interface, rancangan sistem E-PHR terdiri dari KBS Vision (untuk fasilitas kesehatan) dan KBS Mobile (untuk peserta/masyarakat).

Sistem Admin terdiri dari Super Admin, Dashboard Web Admin Dinas Kesehatan, Dashboard Web Admin Fasilitas Kesehatan, dan Sistem Admin Team Operation. Masing-masing bagian memiliki tugas dan fungsi sebagai berikut:

a. Super Admin adalah pihak yang memiliki kewenangan untuk mengambil keputusan atau membuat suatu kebijakan terkait keseluruhan sistem E-PHR yang ada. Pada sistem ini, Super Admin 
dapat diisi oleh Bupati Badung atau Kepala Dinas Kesehatan Kabupaten Badung. Super Admin ini yang menentukan arah pelaksanaan dan pengembangan sistem E-PHR secara keseluruhan, mulai dari aspek perencanaan hingga tahap monitoring serta evaluasi pelaksanaan sistem.

b. Dashboard Web Admin Dinas Kesehatan adalah sistem informasi berbasiskan web yang berisi luaran informasi kesehatan secara keseluruhan di tingkat kabupaten. Pihak yang dapat mengakses sistem ini adalah Dinas Kesehatan Kabupaten Badung, terutama Bidang Pelayanan Kesehatan yang terlibat langsung dalam pelayanan KBS. Informasi ini dihasilkan dari tahapan input dan proses sistem EPHR yang bersumber pada masing-masing layanan, yaitu melalui KBS Vision dan KBS Mobile. Dinas Kesehatan dapat menggunakan informasi kesehatan tersebut untuk keperluan perencanaan program di tingkat kabupaten guna meningkatkan kualitas layanan kesehatan secara keseluruhan di Kabupaten Badung.

c. Dashboard Web Admin Fasilitas Kesehatan adalah sistem informasi berbasiskan web yang berisi informasi kesehatan di tingkat layanan. Pihak yang dapat mengakses sistem ini adalah manajemen di fasilitas kesehatan, seperti pimpinan fasilitas kesehatan maupun pemegang program kesehatan terkait. Informasi kesehatan pada sistem ini juga diperoleh dari tahapan input dan proses yang terjadi pada KBS Vision dan KBS Mobile. Manajemen fasilitas kesehatan dapat menggunakan informasi yang ada untuk keperluan perencanaan program kesehatan, proses monitoring dan evaluasi, serta pengambilan keputusan terkait pembiayaan kesehatan. Pada FKTP, sistem ini juga bermanfaat untuk meningkatkan upaya kesehatan masyarakat melalui pendekatan promotif dan preventif. Sedangkan pada FKRTL, sistem ini dapat bermanfaat untuk meningkatkan upaya kesehatan perorangan melalui pengobatan yang efektif dan efisien.

d. Sistem Admin Team Operation adalah pengelola sistem informasi yang menjembatani Sistem Admin di tingkat Dinas Kesehatan dengan Sistem User Interface di tingkat fasilitas kesehatan. Jika melihat situasi yang sudah berjalan hingga saat ini, pihak yang potensial untuk menjadi Admin Team Operation adalah pengelola Program KBS. Hal ini dikarenakan pemegang Program KBS terlibat langsung 
dalam alur informasi pelayananan kesehatan, terutama dalam menyediakan pelayanan dalam pembiayaan kesehatan. Apabila ke depan E-PHR ini dikembangkan, Sistem Admin Team Operation ini dapat berkedudukan di bawah Dinas Kesehatan seperti kedudukan dari Pemegang Program KBS saat ini, atau juga dapat dikembangkan menjadi suatu lembaga khusus setingkat Unit Pelaksana Teknis Daerah (UPTD).

Sistem User Interface pada rancangan model E-PHR yang dikembangkan di Kabupaten Badung ini terdiri dari KBS Vision, KBS Mobile, dan Integrasi Sistem. Masing-masing bagian memiliki kedudukan dan fungsi sebagai berikut:

a. KBS Vision adalah sistem informasi berbasis web yang digunakan untuk melakukan pencatatan data rekam medis pasien, mulai dari FKTP hingga FKRTL. KBS Vision dirancang untuk dikembangkan menjadi dua versi, yaitu KBS Vision untuk FKTP dan KBS Vision untuk FKRTL. Hal ini dikarenakan sistem pencatatan dan pelaporan data medis pasien di FKTP dan FKRTL memiliki perbedaan dari segi variasi data kesehatan serta jenis layanan yang diberikan. Jika mengacu pada sistem yang sudah ada di FKTP, KBS Vision ini fungsinya sama dengan e-Puskesmas, bahkan dipersiapkan untuk melebihi fungsi e-Puskesmas yang ada saat ini dengan lebih menekankan pada aspek upaya kesehatan masyarakat. Sedangkan jika mengacu pada sistem yang sudah ada di FKRTL, KBS Vision ini fungsinya sama dengan rekam medis elektronik yang sudah ada maupun yang sedang dikembangkan oleh masing-masing FKRTL. Keunggulan dari KBS Vision ini adalah dapat menyediakan sistem yang terintegrasi antara FKTP dengan FKRTL sehingga masingmasing layanan dapat bertukar informasi kesehatan pasien melalui mekanisme keamanan data yang terjaga. Apabila KBS Vision ini dikembangkan untuk semua tingkat layanan mulai dari FKTP hingga FKRTL, maka Kabupaten Badung akan memiliki sistem kesehatan yang terintegrasi sehingga pelayanan kesehatan akan lebih efektif dan efisien. Berdasarkan hal tersebut, KBS Vision ini sangat potensial untuk dikembangkan sehingga sistem-sistem yang sudah ada saat ini yang belum terintegrasi dapat digantikan oleh KBS Vision. 
b. KBS Mobile adalah aplikasi berbasiskan smartphone yang dikembangkan untuk kebutuhan pasien. Pada dasarnya, pasien berhak mengetahui dan mengakses informasi kesehatannya sesuai dengan aturan yang berlaku untuk kepentingan pelayanan kesehatan. Jika mengacu pada sistem yang sudah ada saat ini, KBS Mobile ini identik dengan Mobile JKN yang dikembangkan oleh BPJS Kesehatan. Meskipun demikian, KBS Mobile ini dirancang memiliki fitur yang lebih lengkap dari Mobile JKN. Fitur utama dari KBS Mobile adalah pasien dapat mengakses informasi riwayat kesehatan dasarnya (riwayat pemeriksaan, riwayat pengobatan, riwayat imunisasi, riwayat alegri, dan lainnya) sehingga dapat memudahkan petugas di fasilitas kesehatan untuk memberikan pelayanan. KBS Mobile ini dirancang untuk terintegrasi dengan KBS Vision yang ada di masing-masing FKTP dan FKRTL sehingga pasien dapat mengakses beberapa informasi kesehatan dasar yang berguna serta memang berhak diketahui oleh pasien sesuai dengan aturan yang berlaku. Berdasarkan hal tersebut, maka pengembangan KBS Mobile untuk pasien ini sangat potensial apabila dilakukan seiring dengan pengembangan KBS Vision untuk fasilitas kesehatan.

c. Integrasi Sistem atau bridging system adalah mekanisme yang berfungsi untuk menghubungkan antara KBS Vision dengan KBS Mobile dengan sistem informasi yang sudah ada saat ini. Tujuan dari adanya bridging system ini adalah agar tidak terjadi multiple input pada proses pencatatan dan pelaporan data kesehatan. Jika melihat kondisi ideal dari suatu sistem informasi kesehatan, sistem yang ada hendaknya tidak tumpang tindih satu sama lain. Apabila E-PHR di Kabupaten Badung dikembangkan melalui KBS Vision dan KBS Mobile di tengah keberadaan sistem informasi saat ini di layanan yang masih berbeda-beda dan belum terintegrasi, maka ditakutkan keberadaan KBS Vision dan KBS Mobile ini akan tumpang tindih, bahkan menjadi beban bagi petugas kesehatan di layanan. Jika dilihat dari fungsi dasar masing-masing sistem informasi kesehatan yang sudah ada di Badung, maka dapat dikelompokkan menjadi dua, yaitu sistem informasi untuk pencatatan dan pelaporan serta sistem informasi untuk klaim pembiayaan. Untuk pencatatan dan pelaporan, sistem yang sudah ada di FKTP adalah e-Puskesmas. 
Sedangkan sistem pencatatan dan pelaporan yang sudah ada di FKRTL adalah SIM-RS (beberapa RS) dan SIM-Klinik (beberapa klinik swasta). Sistem-sistem ini fungsinya sama dengan KBS Vision, sehingga apabila pemerintah Kabupaten Badung ingin menciptakan sistem informasi kesehatan yang terintegrasi, pilihan utamanya adalah dengan mengganti sistem-sistem informasi kesehatan yang sudah ada dengan KBS Vision serentak di FKTP hingga FKRTL.

Berbeda halnya dengan fungsi sistem informasi untuk klaim pembiayaan kesehatan, di Badung saat ini sudah tersedia P-Care di tingkat FKTP dan V-Claim di tingkat FKRTL. Pengembangan dari KBS Vision dan KBS Mobile adalah untuk pencatatan dan pelaporan data kesehatan (fasilitas kesehatan dan pasien), bukan untuk sistem klaim pembiayaan kesehatan. Hal ini menyebabkan P-Care dan V-Claim tetap diperlukan meskipun KBS Vision dan KBS Mobile dikembangkan. Apabila dikembangkan di semua tingkatan layanan, KBS Vision ini diharapkan dapat terintegrasi (bridging) dengan P-Care dan V-Claim yang sudah dikembangkan oleh BPJS sehingga pencatatan dan pelaporan data kesehatan serta proses klaim pembiayaan kesehatan dapat berjalan dengan baik. Dengan demikian, dapat disimpulkan sistem pencatatan dan pelaporan oleh fasilitas kesehatan dilakukan melalui KBS Vision, klaim pembiayaannya melalui P-Care dan V-Claim, dan pasien dapat mengakses riwayat kesehatan dan pelayanan kesehatan melalui KBS Mobile. 


\section{E-PHR dalam bentuk aplikasi mobile di handphone pengguna (KBS Mobile)}

\section{Fitur utama}

\section{HALAMAN LOGIN DAN PENDAFTARAN}

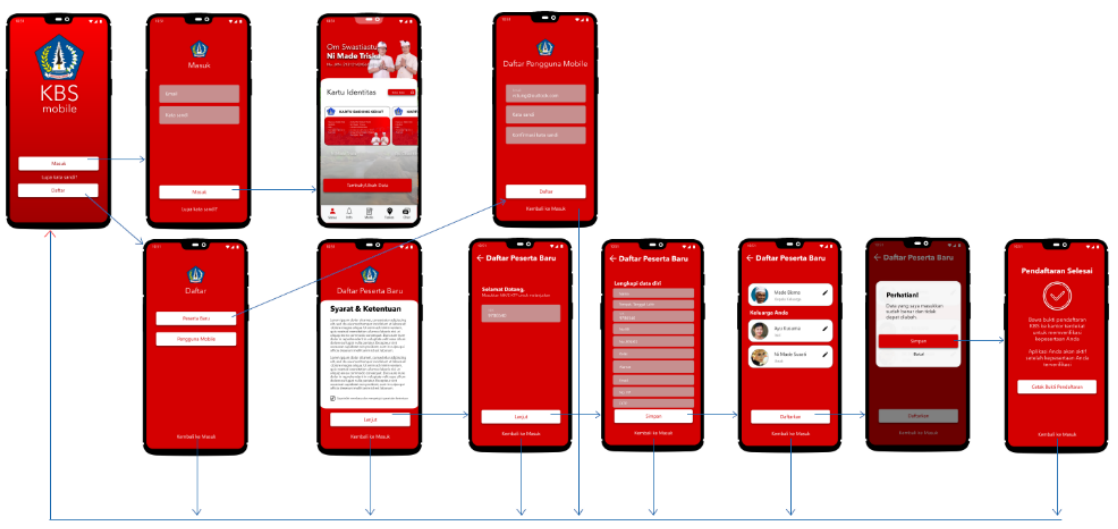

Gambar 25. Halaman Login dan Pendaftaran pada Aplikasi KBS Mobile

Menu pertama adalah untuk pendaftaran kepesertaan KBS Mobile dan menu login. Pada prinsipnya, aplikasi KBS Mobile ini dapat di-install secara perseorangan pada smartphone masing-masing maupun melalui keluarga. Hal ini dikarenakan target dari pengguna dari aplikasi ini adalah minimal dalam satu keluarga terdapat satu smartphone yang sudah terinstall aplikasi KBS Mobile. Langkah ini diambil untuk mengantisipasi jika dalam satu keluarga terdapat anak-anak atau lansia yang belum bisa/mampu menggunakan smartphone untuk mengakses KBS Mobile. Metode ini diharapkan mampu memperluas cakupan penggunaan KBS Mobile.

Pada menu Pendaftaran Kepesertaan, seseorang dapat langsung mendaftarkan diri menjadi peserta KBS Mobile dengan mengisi data diri pada aplikasi. Seseorang juga dapat mendaftarkan anggota keluarga lainnya untuk menjadi peserta KBS Mobile. Setelah data diri kepesertaan diisi dengan lengkap, peserta dapat mencetak bukti pendaftaran tersebut pada aplikasi KBS Mobile dan membawa bukti pendaftaran tersebut ke pengelola KBS di Dinas Kesehatan untuk melakukan verifikasi dan aktivasi kepesertaan KBS Mobile. Apabila status kepesertaan KBS Mobile sudah aktif, maka setiap peserta dapat mengakses aplikasi KBS Mobile melalui login 
dengan alamat email dan kata sandi yang sebelumnya sudah didaftarkan di awal.

\section{DASHBOARD DAN HALAMAN STATUS}

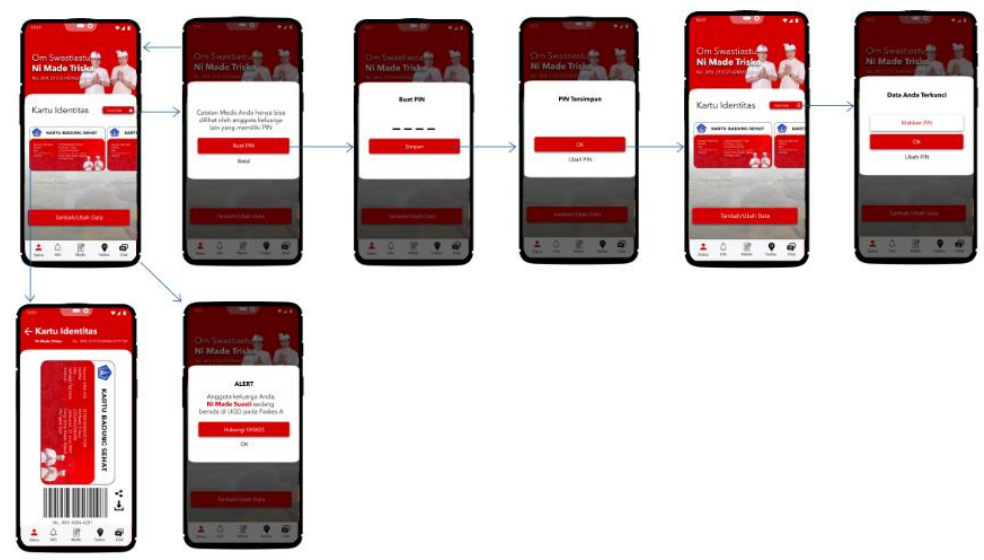

Gambar 26. Dashboard dan Halaman Status pada Aplikasi KBS Mobile

Peserta yang sudah berhasil melakukan aktivasi kepesertaan dapat mulai mengakses aplikasi KBS Mobile dan menikmati fitur layanan yang tersedia. Fitur pertama adalah peserta dapat mengunci data kepesertaannya agar riwayat kesehatannya tidak bisa dilihat oleh anggota keluarga yang lain. Caranya adalah dengan menambahkan pin pada aplikasi Mobile KBS. Jika data kepesertaan ini dikunci, maka anggota keluarga yang lain tidak bisa melihat riwayat kesehatan dari yang bersangkutan. Fitur selanjutnya adalah untuk kegawatdaruratan, yaitu berupa pesan peringatan/notifikasi pada aplikasi KBS Mobile apabila salah satu anggota keluarga yang terdaftar dalam KBS Mobile mengalami musibah. Jika seseorang mengalami kegawatdaruratan, seperti kecelakaan, maka aplikasi Mobile KBS akan otomatis memberikan notifikasi kepada anggota keluarga lainnya bahwa ada anggota keluarga yang sedang dirawat. Notifikasi akan berisi unit layanan serta nama fasilitas kesehatan tempat pasien tersebut dirawat. Fitur selanjutnya yang tidak kalah penting adalah kartu KBS digital. Kartu digital ini berfungsi untuk mengakses layanan di fasilitas kesehatan serta untuk klaim KBS. Fungsi dari kartu KBS digital ini juga hampir sama dengan kartu KBS dan KIS yang sudah dimiliki saat ini oleh pasien. 


\section{CATATAN MEDIS}

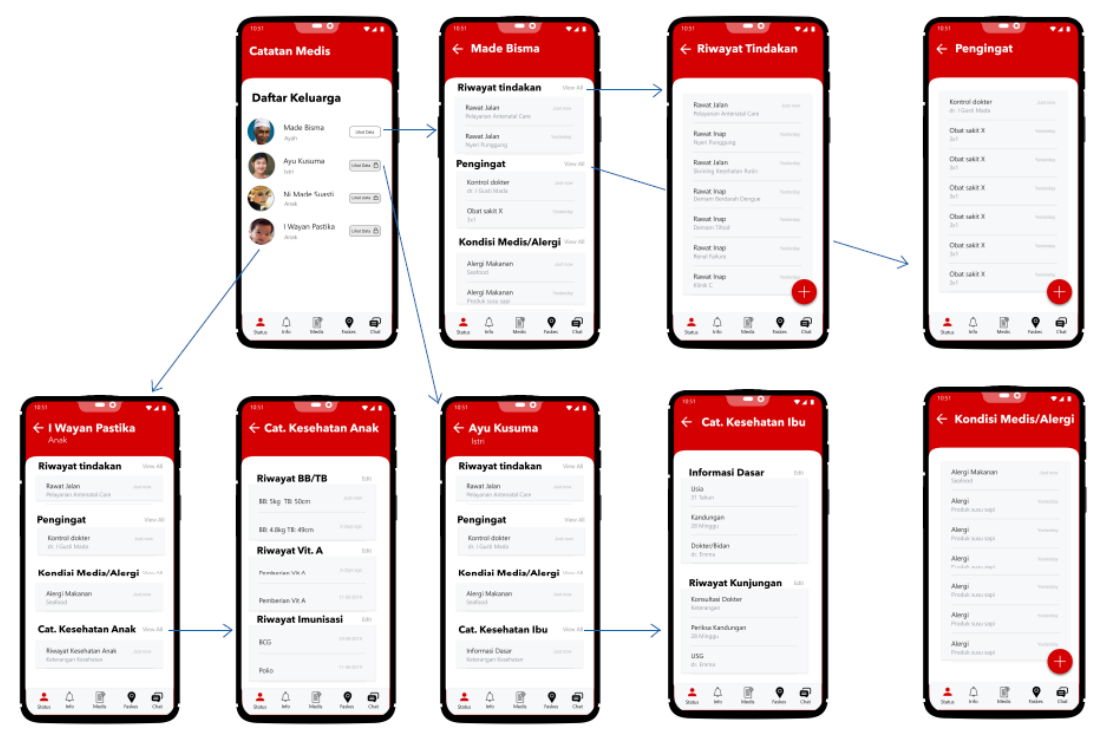

Gambar 27. Catatan Medis pada Aplikasi KBS Mobile

Fitur utama dari aplikasi KBS Mobile adalah catatan medis pasien. Pada aplikasi Mobile KBS yang didaftarkan, daftar pasien tersedia dalam satu keluarga. Meskipun demikian, hanya peserta yang memiliki pin yang bisa membuka riwayat kesehatan. Informasi kesehatan yang dapat diakses melalui KBS Mobile adalah sebagai berikut:

a. Riwayat tindakan pengobatan/pelayanan kesehatan yang pernah diakses, yaitu terdiri dari riwayatat rawat jalan dan rawat inap.

b. Pengingat, yaitu fitur untuk mengingatkan pasien terkait jadwal minum obat, kontrol rutin, dan jadwal pemeriksaan/pengobatan lainnya.

c. Riwayat Alergi, yaitu fitur untuk mencatat riwayat alergi pasien terkait dengan alergi obat, makanan, maupun kondisi alergi terhadap sesuatu (debu, dingin, dan sebagainya).

d. Catatan kesehatan anak, yaitu fitur yang menyediakan informasi terkait riwayat imunisasi, pemberian vitamin A, riwayat pengukuran berat badan dan tinggi badan, serta status gizi anak.

e. Catatan kesehatan ibu hamil, yaitu fitur yang menyediakan informasi terkait usia kahamilan, riwayat pemeriksaan kehamilan, riwayat 
kunjungan, pemeriksaan USG, risiko kehamilan, status gizi, dan riwayat imunisasi ibu hamil.

\section{FASILITAS KESEHATAN}

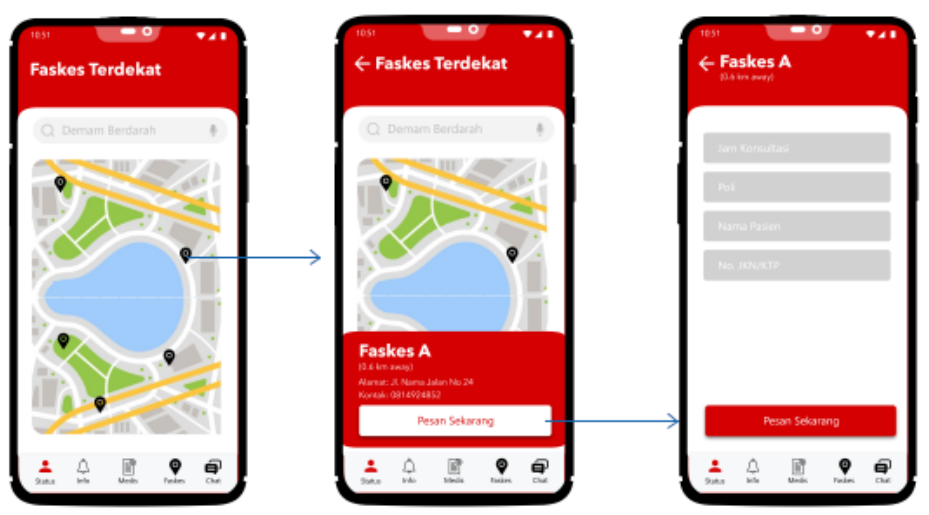

Gambar 28. Fasilitas Kesehatan pada Aplikasi KBS Mobile

Aplikasi KBS Mobile juga menyediakan fitur fasilitas kesehatan terdekat yang bisa diakses oleh peserta, mulai dari FKTP, FKRTL, hingga dokter umum dan dokter gigi praktik mandiri. Aplikasi KBS Mobile ini juga memungkinkan untuk melakukan pemesanan antrian secara online untuk konsultasi atau mengakses layanan pengobatan di fasilitas kesehatan. Fitur ini juga dapat difungsikan untuk melakukan pemesan ambulans jika ada kasus gawat darurat, sehingga dapat mengurangi angka kesakitan dan kematian. 


\section{Fitur pengembangan}

\section{HALAMAN INFORMASI KESEHATAN}

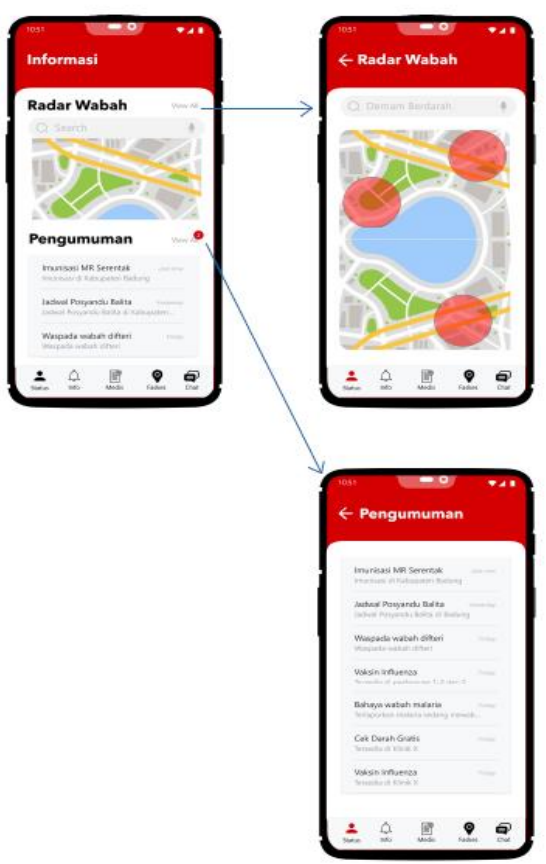

Gambar 29. Halaman informasi kesehatan pada Aplikasi KBS Mobile

Keunggulan dari Aplikasi KBS Mobile dibandingkan dengan Mobile JKN adalah adanya fitur informasi kesehatan untuk upaya kesehatan masyarakat, yaitu lebih menekankan upaya preventif dan promotif. Informasi kesehatan yang tersedia pada fitur ini adalah Radar Wabah dan Pengumuman. Fitur ini dapat dimanfaatkan oleh layanan kesehatan, terutama oleh Puskesmas dan Puskesmas Pembantu untuk mencegahan penyebaran wabah di masyarakat. Apabila di layanan terjadi peningkatan kasus yang berpotensi wabah (seperti Demam Berdarah Dengue), maka secara otomatis masyarakat yang berada di wilayah puskesmas tersebut akan memperoleh notifikasi terkait potensi wabah yang terjadi sehingga dapat mengantisipasi agar tidak terkena wabah serta ikut dalam upaya pencegahan penyebaran wabah. Pada fitur Pengumuman, layanan dapat menyebarkan informasi terkait promosi kesehatan, program kesehatan puskesmas, serta informasi pelayanan kesehatan. Informasi yang disebarkan melalui fitur Pengumuman ini dapat bersifat umum yang bisa 
diakses oleh seluruh peserta, maupun bersifat khusus yang hanya bisa diakses oleh kelompok tertentu (ibu hamil, remaja, dan sebagainya).

\section{OBROLAN (CHAT)}

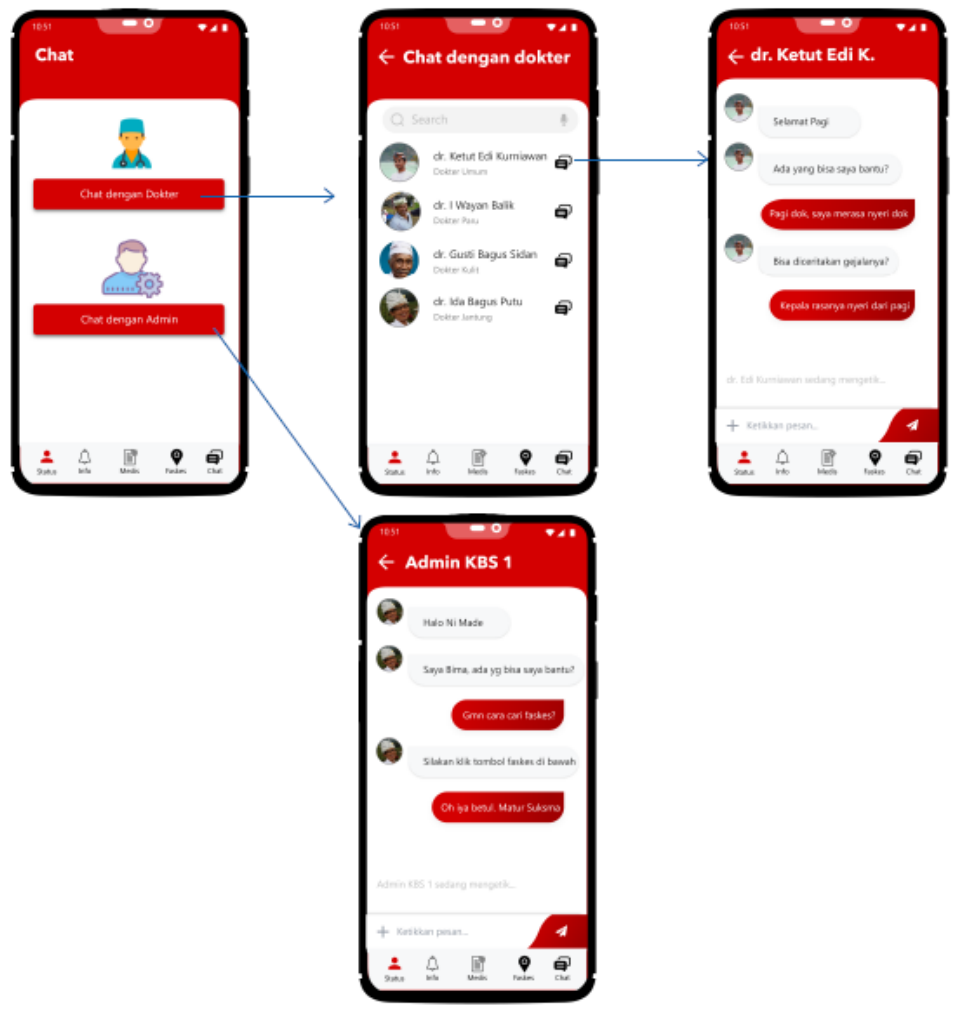

Gambar 30. Fitur chat pada Aplikasi KBS Mobile

Fitur pengembangan yang bermanfaat untuk meningkatkan kualitas pelayanan KBS adalah adanya fitur obrolan (chat). Fitur chat ini terdiri dari chat dengan dokter pemberi layanan (dokter umum dan gigi) serta dengan admin pengelola KBS. Pada fitur chat dengan dokter, peserta dapat melakukan janjian maupun konsultasi masalah kesehatan yang dialami. Apabila dirasa perlu melakukan pemeriksaan lebih lanjut, maka pasien dapat diarahkan untuk langsung datang ke fasilitas kesehatan terdekat untuk memperoleh penanganan lebih lanjut. Jika peserta memiliki keluhan serta memerlukan konsultasi terkait layanan KBS, maka peserta dapat menghubungi admin pemegang program KBS melalui fitur chat yang ada pada Aplikasi KBS Mobile. Fitur ini diharapkan dapat menjadi media 
komunikasi yang efektif dan efisien antara peserta KBS dengan penyedia layanan KBS.

\section{E-PHR dalam bentuk aplikasi dekstop di komputer layanan (KBS Vision)}

\section{Fitur utama}
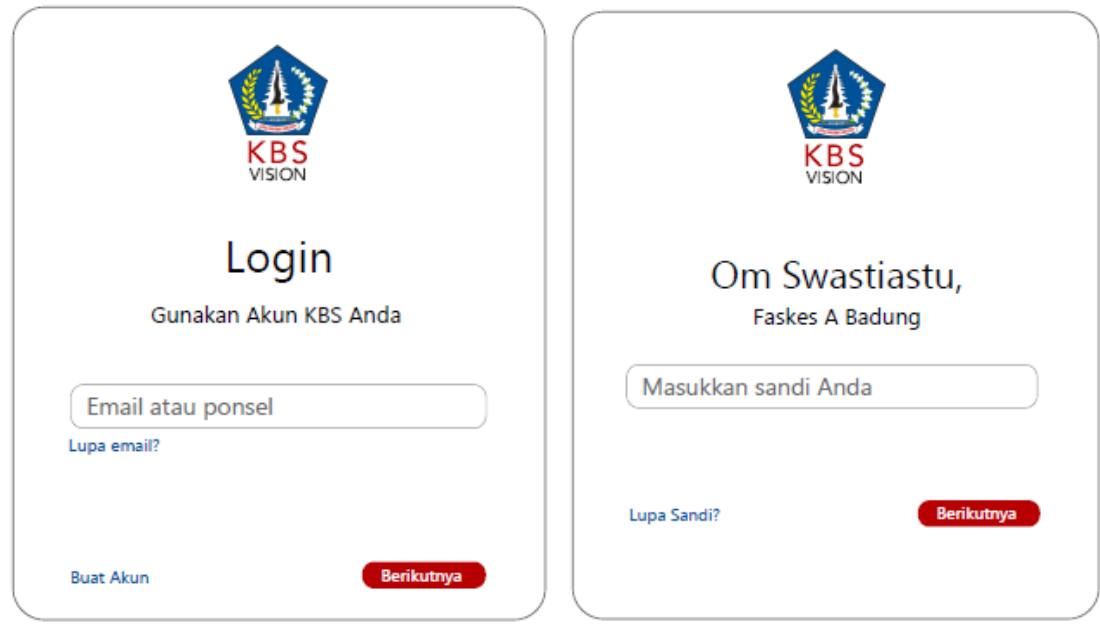

Gambar 31. Tampilan halaman login pada KBS Vision

KBS Vision di tingkat fasilitas kesehatan dikembangkan dalam bentuk aplikasi berbasis web serta dapat diakses di masing-masing komputer/laptop. Jika dilihat dari rancangan bangun sistem, KBS Vision hampir sama dengan e-Puskesmas maupun SIM-RS yang sudah ada. Hanya saja fitur yang terdapat dalam KBS Vision lebih lengkap. Pengembangan KBS Vision dilakukan dengan mengakomodasi kebutuhan FKTP dan FKRTL sehingga terdapat dua versi KBS Vision. Tampilan awal untuk login pada KBS Vision seperti ditunjukkan gambar di atas. Akses masuk terhadap KBS Vision dilakukan dengan memasukkan akun yang sudah terdaftar. 


\section{DASHBOARD KBS VISION}

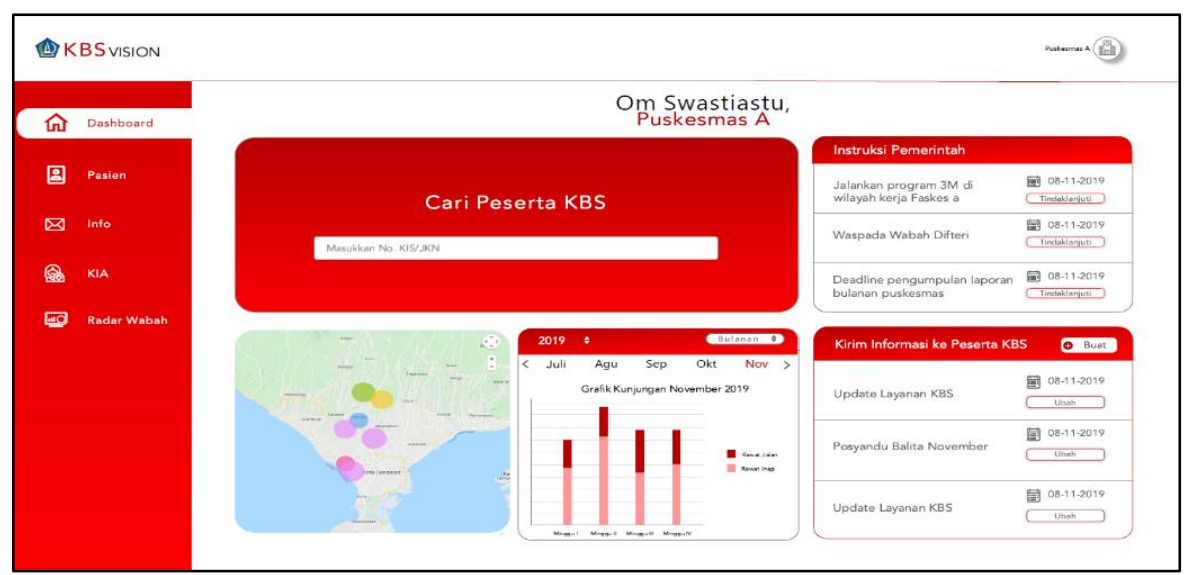

Gambar 32. Tampilan dashboard pada KBS Vision

Tampilan pada dashboard KBS Vision sangat sederhana dan bersifat user friendly sehingga memudahkan petugas dalam menggunakan KBS Vision. Setelah berhasil login menggunakan akun petugas yang telah terdaftar, terdapat beberapa menu yang dapat dimanfaatkan untuk fungsi pencatatan maupun pelaporan data medis pasien. Berikut adalah jenis dan fungsi masing-masing menu pada KBS Vision:

a. Menu Navigasi, yaitu menu yang terletak di bagian kiri KBS Vision. Pada menu navigasi ini terdiri dari Dashboard, Pasien, Info, KIA, dan Radar Wabah.

b. Grafik kunjungan pasien, yaitu fitur yang dapat digunakan oleh fasilitas kesehatan untuk mengetahui tingkat kunjungan pasien sesuai dengan poli layanan yang diakses. Tampilan grafik juga dapat diatur secara harian, mingguan, hingga bulanan.

c. Peta Wabah, yaitu fitur yang dapat memberikan informasi terkait dengan wabah yang sedang terjadi serta potensi wabah yang akan terjadi di wilayah kerja puskesmas/fasilitas kesehatan terkait. Fitur ini bermanfaat untuk pemantauan wilayah setempat oleh FKTP, terutama Puskesmas. Fitur ini pada KBS Vision versi FKRTL dapat diganti dengan grafik/informasi lain sesuai dengan kebutuhan layanan.

d. Cari Peserta KBS, yaitu fitur untuk melakukan pencarian data pasien yang sebelumnya pernah berobat/mengakses layanan kesehatan. Petugas tinggal memasukkan no JKN/KIS dari pasien untuk 
memudahkan pencarian. Fitur ini juga dapat dilakukan otomatisasi dengan cara melakukan scan terhadap barcode pada kartu KBS, baik kartu yang dicetak maupun kartu digital yang terdapat pada Aplikasi KBS Mobile.

e. Instruksi pemerintah, yaitu fitur yang berisi arahan dari Dinas Kesehatan kepada masing-masing fasilitas kesehatan. Arahan yang dimaksud dapat berupa pengingat untuk pelaporan program maupun himbauan terkait kesiapsiagaan wabah.

f. Informasi ke Peserta KBS, yaitu fitur yang dapat dimanfaatkan oleh fasilitas kesehatan untuk menyebarkan informasi kesehatan kepada seluruh peserta KBS yang terdaftar di fasilitas kesehatan tersebut. Informasi kesehatan yang disebarkan dapat berupa informasi yang sifatnya umum maupun spesifik sesuai dengan target penerima serta dapat dilakukan filter sesuai dengan karakteristik demografi target penerima. Informasi ini nanti akan diterima oleh peserta melalui fitur notifikasi pada Aplikasi KBS Mobile.

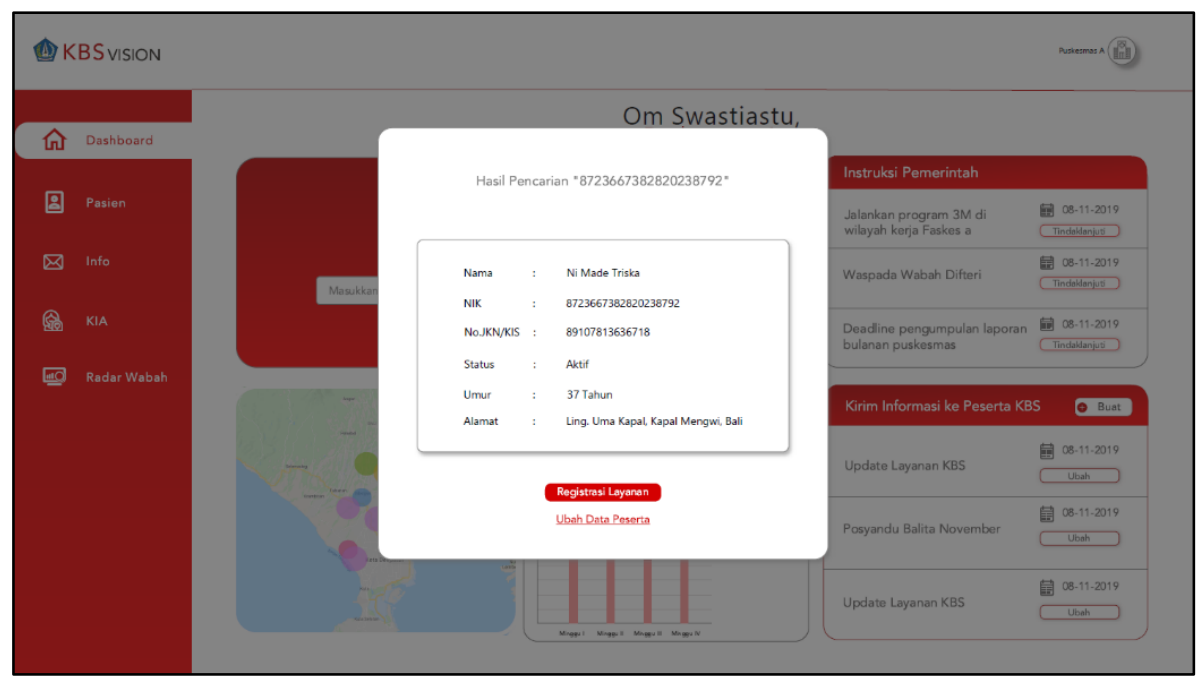

Gambar 33. Tampilan Menu Pencarian Data Pasien pada Dashboard

Apabila pasien mengakses layanan di fasilitas kesehatan, petugas dapat melakukan menu pencarian data pasien (untuk pasien lama) serta melakukan penambahan data pasien (untuk pasien baru) pada menu Pencarian Data Pasien yang terdapat pada Dashboard. Petugas dapat memasukkan NIK maupun nomor KIS/JKN yang ada pada kartu KBS Digital 
agar bisa muncul data pasien yang pernah tercatat sebelumnya. Selain menggunakan metode memasukkan data nomor JKN/KIS secara manual, proses ini juga dapat dipercepat dengan menggunakan scan bar code yang terdapat dalam kartu KBS yang dicetak maupun dalam bentuk Kartu KBS Digital. Apabila nomor JKN/KIS sudah berhasil dimasukkan, maka pada menu Dashboard akan tampil data pasien seperti nama lengkap pasien, NIK, nomor JKN/KIS, status kepesertaan, usia, serta alamat lengkap pasien. Pada proses ini, petugas juga dapat melakukan validasi serta memperbaharui database pasien yang bersangkutan seandainya ada perubahan data oleh pasien. Perubahan terhadap data pasien dilakukan oleh petugas serta dilakukan atas seizin dari pasien yang bersangkutan.

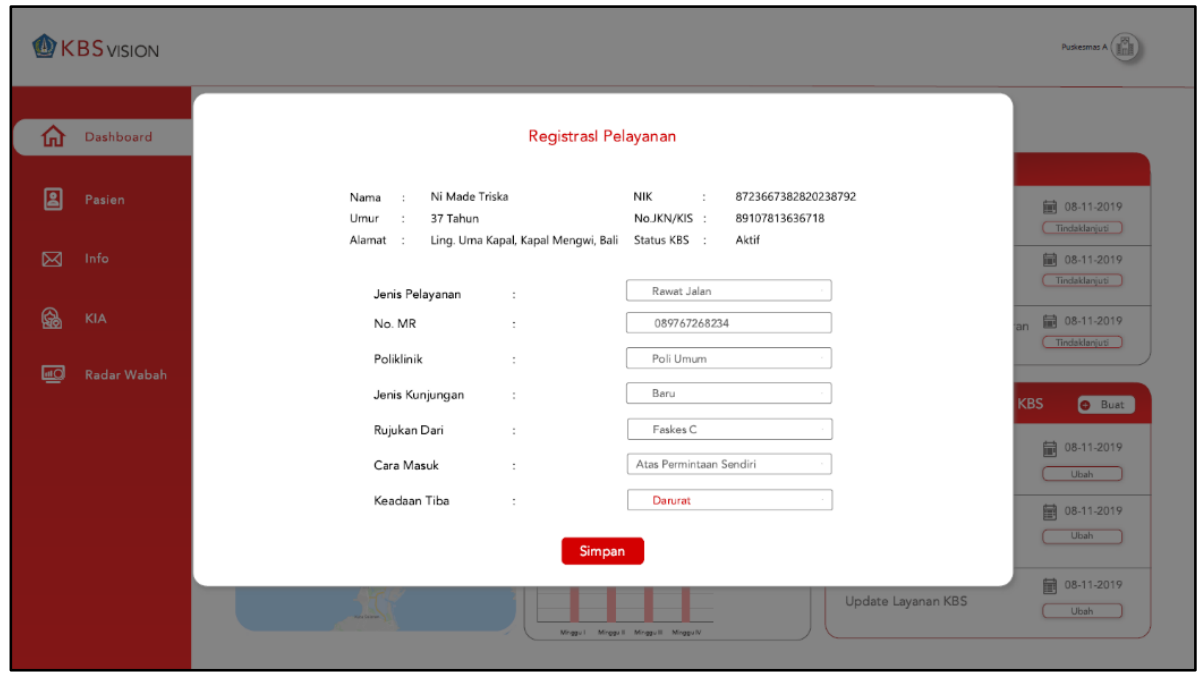

Gambar 34. Tampilan Registrasi Pelayanan pada Menu Dashboard

Fitur lain yang terdapat pada KBS Vision adalah menu Registrasi Pelayanan. Seluruh pasien yang datang ke fasilitas layanan didaftarkan pada menu Registrasi Pelayanan. Pada fitur ini berisi data terkait jenis pelayanan yang diakses pasien, nomor rekam medis pasien, poli layanan yang diakses, jenis kunjungan (baru atau lama), jenis rujukan, serta keadaan pasien saat tiba. Keseluruhan data ini akan tersimpan menjadi data riwayat kunjungan pasien serta pengobatan dari pasien di layanan. 


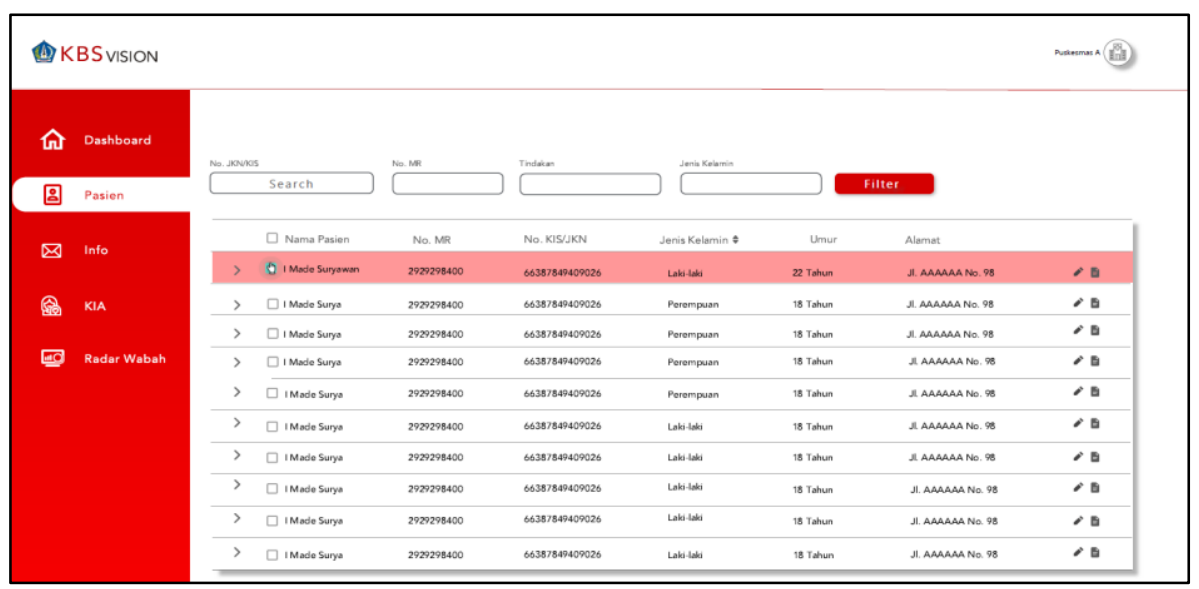

Gambar 35. Tampilan Menu Pasien pada KBS Vision

Menu Pasien berfungsi sebagai database untuk rekam medis elektronik pasien di masing-masing fasilitas kesehatan. Seluruh pasien yang pernah mengakses layanan kesehatan akan tercatat melalui sistem rekam medis elektronik. Petugas di layanan akan dapat melakukan pencarian data pasien sesuai dengan pilihan menu filter, yang terdiri dari berdasarkan nomor JKN/KIS, nomor Rekam Medis, Tindakan, serta Jenis Kelamin. Pada menu ini, petugas juga dapat melakukan analisis sederhana untuk mengetahui 10 besar penyakit, jenis penyakit dengan prevalensi tertinggi dan terendah, poli layanan yang paling banyak diakses, serta data kesakitan berdasarkan karakteristik sosiodemografi dari pasien yang mengakses layanan kesehatan.

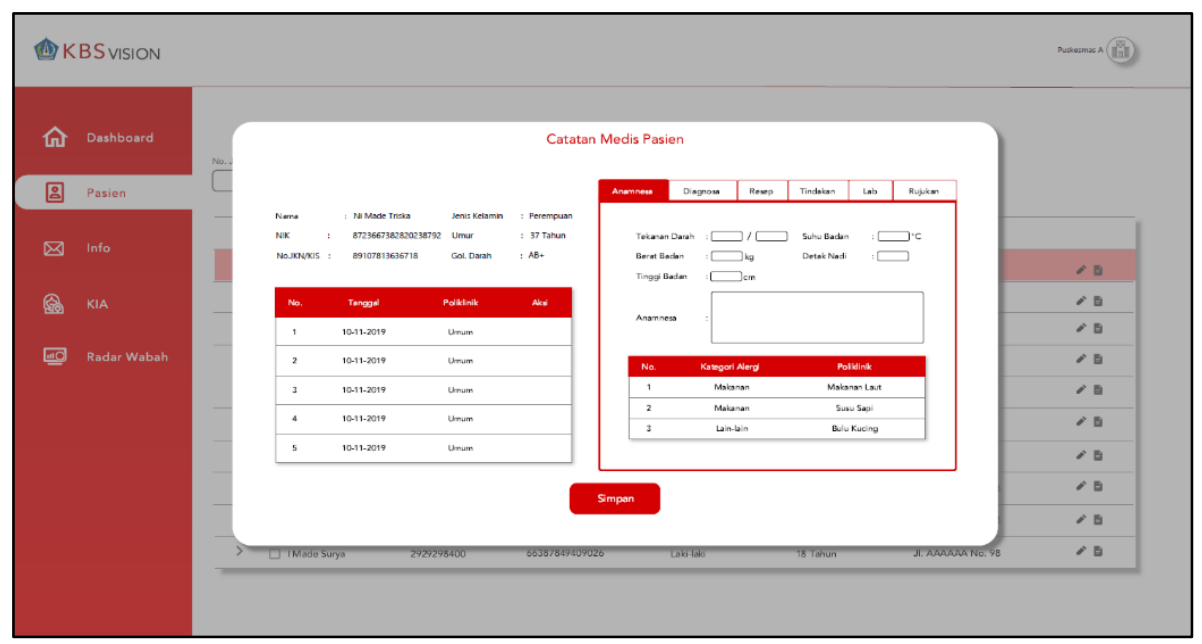

Gambar 36. Menu Catatan Medis Pasien 
Menu yang paling penting dalam KBS Vision adalah Menu Catatan Medis Pasien. Menu ini adalah rekam medis pasien secara elektronik. Seluruh pasien yang mengakses layanan kesehatan akan tercatat segala jenis tindakan medis yang diberikan. Menu Catatan Medis Pasien ini terdiri dari riwayat tanggal kunjungan, tindakan medis, anamnesa, diagnosis, resep obat, tindakan medis, hasil pemeriksaan laboratorium, dan riwayat rujukan. Keseluruhan data ini dapat diisi oleh masing-masing petugas kesehatan di masing-masing poli melalui komputer yang terhubung jaringan internet, sehingga database pasien yang lengkap dapat otomatis tercatat dan tersimpan pada KBS Vision. Database ini terhubung dengan KBS Mobile sehingga beberapa data kesehatan dasar pasien pada KBS Vision akan dapat diakses melalui KBS Mobile.

\section{Fitur pengembangan}

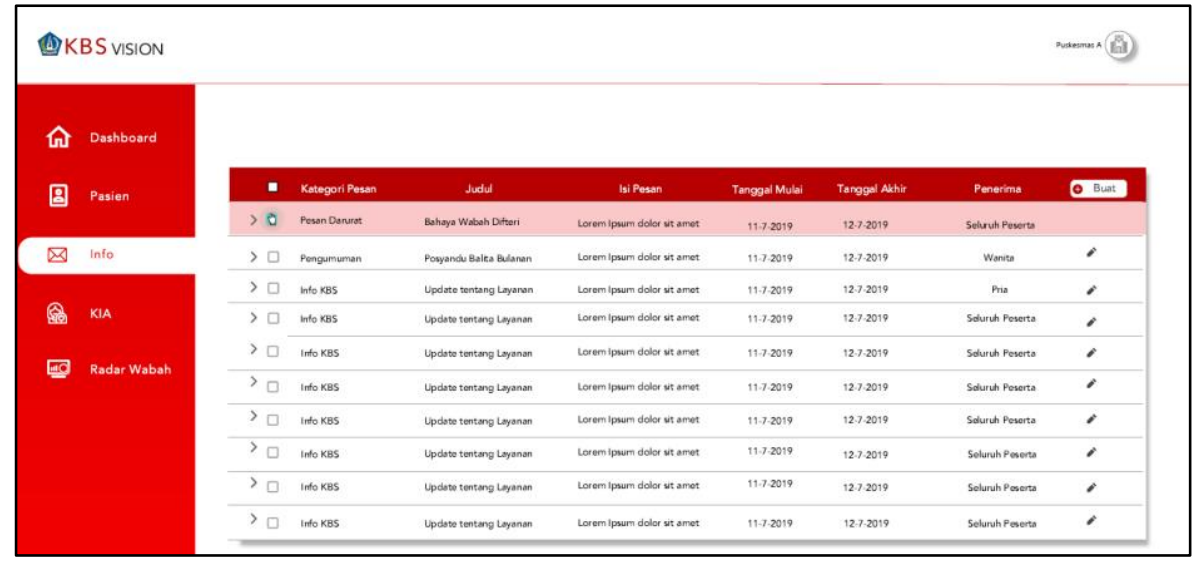

Gambar 37. Menu Informasi Kesehatan

Selain fitur utama pada KBS Vision yang bermanfaat untuk keperluan pelayanan kesehatan berupa pengobatan, terdapat fitur pengembangan yang dapat dimanfaatkan oleh layanan untuk upaya promotif dan preventif. Salah satu fitur yang tersedia adalah Menu Informasi Kesehatan. Fitur ini dapat dikembangkan di FKTP maupun di FKRTL yang disesuaikan dengan kebutuhan layanan. Apabila fasilitas kesehatan ingin menyebarkan informasi kesehatan tertentu kepada masyarakat, maka informasi tersebut dapat disebarkan melalui KBS Vision yang nantinya dapat diakses oleh masyarakat melalui fitur notifikasi yang ada pada KBS Mobile. 


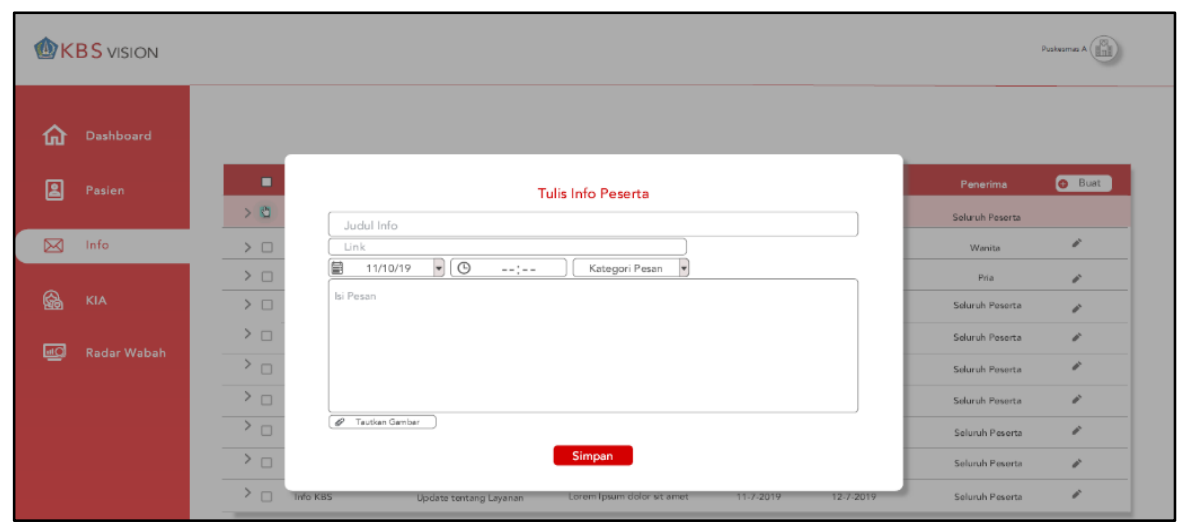

Gambar 38. Tampilan Menu Informasi Kesehatan

Informasi yang disebarkan dapat dikelompokkan berdasarkan jenis pesan (pengumuman, informasi KBS, dan sebagainya), judul informasi kesehatan, isi pesan, tanggal mulai penyebaran pesan, tanggal berakhir penyebaran pesan, frekuensi penyampaian pesan, serta target penerima. Informasi yang disebarkan ini dapat diatur apakah untuk masyarakat umum (semua peserta KBS) atau hanya untuk kelompok tertentu sesuai dengan jenis layanan yang diinformasikan (remaja, lansia, ibu hamil, dan sebagainya). Fitur informasi kesehatan ini bermanfaat untuk upaya promosi kesehatan kepada masyarakat untuk meningkatkan upaya promotif dan preventif terhadap suatu penyakit atau masalah kesehatan lainnnya. Fitur ini juga dapat dimanfaatkan untuk pengingat jadwal pelayanan kesehatan (imunisasi, pengobatan, dan sebagainya). Selain untuk informasi kesehatan, fitur ini juga dapat disisipkan survei untuk mengetahui penilaian masyarakat terkait kualitas pelayanan yang diberikan oleh fasilitas kesehatan. 


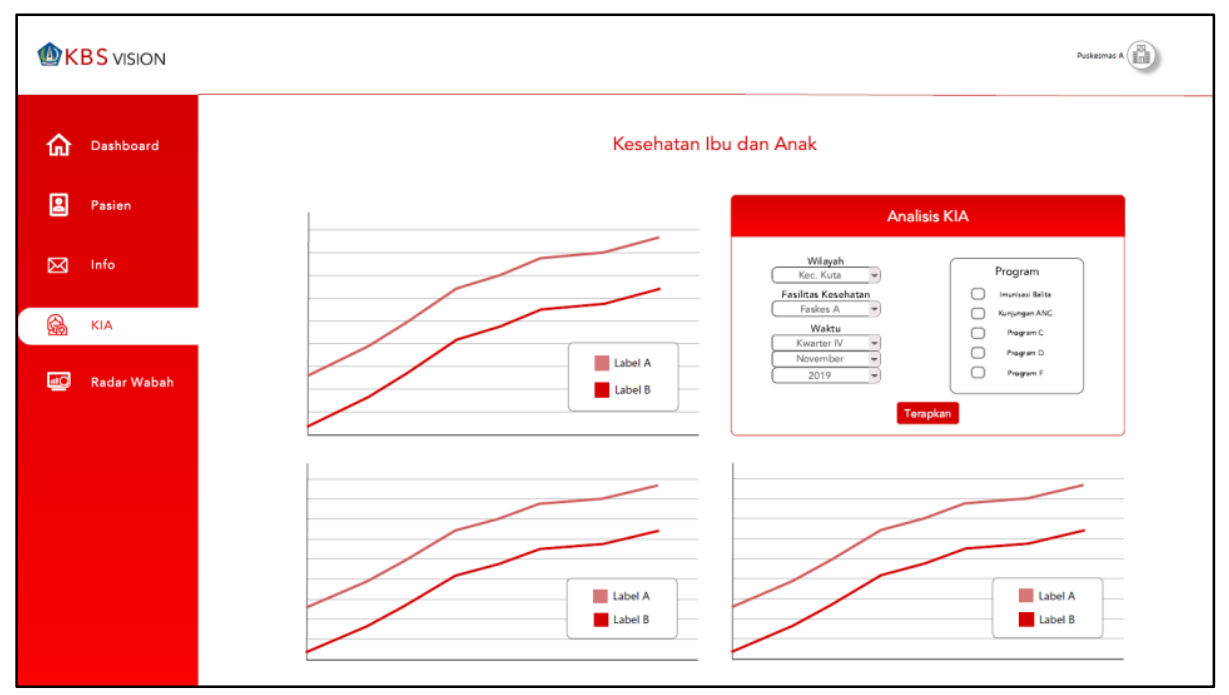

Gambar 39. Menu Kesehatan Ibu dan Anak (KIA)

KBS Vision juga dirancang untuk mengakomodasi layanan Kesehatan Ibu dan Anak (KIA). Untuk ibu hamil, menu KIA ini bermanfaat untuk pemantauan kehamilan, status gizi ibu hamil, serta risiko kehamilan. Menu ini juga dapat digunakan mengingatkan ibu hamil untuk memeriksakan kehamilan melalui fitur informasi kesehatan. Untuk kesehatan bayi hingga balita, fitur ini dapat digunakan untuk pemantauan status gizi dan kesehatan anak. Fitur ini bermanfaat untuk pemantauan wilayah setempat.

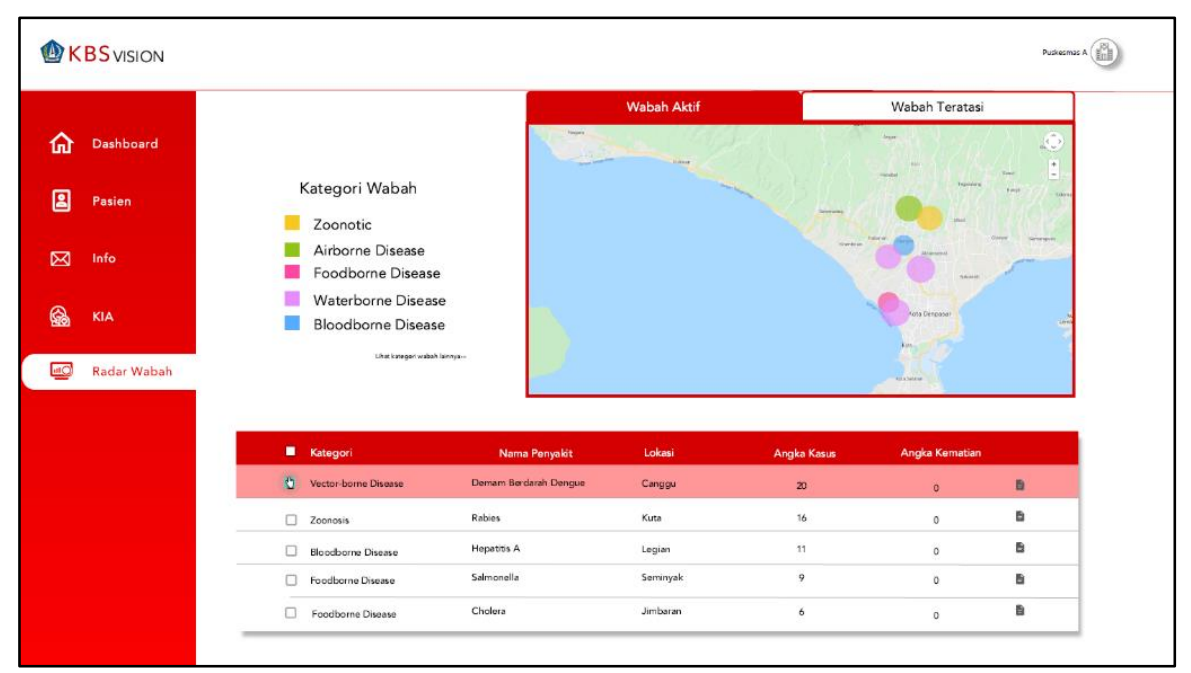

Gambar 40. Fitur Radar Wabah 
KBS Vision juga dapat difungsikan untuk keaspadaan dini (warning system) terhadap penyakit-penyakit yang berpotensi menimbulkan wabah. Apabila di fasilitas kesehatan terdapat peningkatan jumlah kasus suatu penyakit infeksi yang berisiko wabah (seperti Demam Berdarah Dengue), maka fitur ini akan otomatis menampilkan grafik dan peta digital. Petugas kesehatan di layanan dapat mengetahui trend penyakit yang berpotensi menimbukan wabah sehingga layanan kesehatan dapat melakukan langkahlangkah untuk pencegahan penyakit. Selain informasi potensi wabah yang dapat diakses oleh petugas kesehatan di layanan, informasi terkait potensi wabah juga dapat diakses oleh masyarakat melalui aplikasi KBS Mobile. Notifikasi terkait informasi potensi wabah serta cara pencegahannya akan diperoleh otomatis melalui KBS Mobile, sehingga masyarakat dapat waspada serta dapat berpartisipasi secara aktif untuk mencegah atau mengurangi risiko terjadinya wabah. Fitur pengembangan ini akan sangat bermanfaat untuk keperluan surveilans penyakit di masyarakat, terutama bagi FKTP. Sedangkan untuk KBS Vision pada FKRTL, menu ini dapat disesuaikan dengan kebutuhan layanan sehingga surveilans penyakit tetap dapat dilakukan.

\section{Alternatif pengembang KBS}

\section{Dikembangkan secara mandiri}

Sistem E-PHR apabila dikembangkan di Kabupaten Badung tidak dapat berdiri sendiri, tetapi memerlukan kerjasama lintas sektor dalam pengelolaannya. Jika dilihat dari kebutuhan personel dalam mengembangkan suatu sistem informasi, maka setidaknya diperlukan beberapa tenaga sumber daya manusia dengan masing-masing keahlian sebagai berikut:

Tabel 18. Kebutuhan Personil untuk Pengembangan Sistem E-PHR

\begin{tabular}{|c|c|c|}
\hline No & Jenis Tenaga Teknis & Rincian \\
\hline 1 & Ahli Sistem Informasi & $\begin{array}{l}\text { Pendidikan: } \\
\text { - } \quad \text { Tingkat pendidikan minimal S1/D4 dengan keahlian } \\
\text { bidang telematika (Sistem Informasi/ Teknologi } \\
\text { Informasi/ Sarjana Komputer/ Teknik Elektro). } \\
\text { Uraian Tugas: } \\
\text { - } \\
\quad \text { Memiliki pengetahuan tentang bisnis secara umum, } \\
\quad \text { pengetahuan yang memadai mengenai proses bisnis } \\
\text { organisasi, kebijakan organisasi, perilaku organisasi }\end{array}$ \\
\hline
\end{tabular}




\begin{tabular}{|c|c|c|}
\hline No & Jenis Tenaga Teknis & Rincian \\
\hline & & $\begin{array}{l}\text { dan aspek-aspek organisasi lainnya sesuai dengan } \\
\text { sistem yang akan ditangani. } \\
\text { - Memahami metodelogi pengembangan sistem } \\
\text { informasi, sehingga dapat menemukan dan } \\
\text { menggunakan metodelogi pengembangan yang paling } \\
\text { tepat dan sesuai dengan kondisi nyata dilapangan. } \\
\text { Memiliki kemampuan untuk bekerja sama dalam } \\
\text { team-work dalam melakukan } \\
\text { pemeliharaan/pengembangan sistem informasi atau } \\
\text { aplikasi-aplikasi yang ditangani. }\end{array}$ \\
\hline 2 & Ahli Sistem Analisis & $\begin{array}{l}\text { Pendidikan: } \\
\text { - } \\
\text { Tingkat pendidikan minimal S1/D4 dengan keahlian } \\
\text { bidang telematika (Sistem Informasi/ Teknologi } \\
\text { Informasi/ Sarjana Komputer/ Teknik Elektro). } \\
\text { Uraian Tugas: } \\
\text { - } \\
\text { Memiliki kemampuan untuk memecahkan masalah- } \\
\text { (dekomposisi). Memecah masalah-masalah tersebut } \\
\text { kedalam bagian-bagiannya, menganalisisnya dan } \\
\text { kemudian dapat merangkainya menjadi suatu sistem } \\
\text { yang dapat mengatasi permasalahan-permasalahan } \\
\text { tersebut. } \\
\text { Memiliki pengetahuan dan keahlian tentang teknik } \\
\text { pengolahan data, teknologi komputer dan } \\
\text { pemograman komputer. Keahlian teknis yang harus } \\
\text { dimiliki adalah termasuk keahlian dalam penggunaan } \\
\text { alat dan teknik untuk pengembangan perangkat } \\
\text { lunak aplikasi serta keahlian dalam menggunakan } \\
\text { komputer. } \\
\text { Mempunyai kemampuan untuk meletakkan } \\
\text { permasalahan-permasalahan kompleks yang } \\
\text { dihadapi oleh pengguna, memecah-mecah masalah } \\
\text { tersebut ke dalam bagian-bagiannya, } \\
\text { menganalisisnya dan kemudian harus dapat } \\
\text { merangkainya kembali menjadi suatu sistem yang } \\
\text { dapat mengatasi permasalahan tersebut. } \\
\text { Mempunyai kemampuan untuk mengadakan } \\
\text { komunikasi baik secara lisan maupun tertulis. } \\
\text { Keahlian ini diperlukan di dalam wawancara, } \\
\text { presentasi, rapat dan pembuatan laporan-laporan. }\end{array}$ \\
\hline 3 & Ahli Database Designer & $\begin{array}{l}\text { Pendidikan: } \\
\text { - } \quad \text { Tingkat pendidikan minimal S1/D4 dengan keahlian } \\
\text { bidang telematika (Sistem Informasi/ Teknologi } \\
\text { Informasi/ Sarjana Komputer/ Teknik Elektro). } \\
\text { Uraian Tugas: } \\
\quad \text { Memiliki keahlian teknis dalam penggunaan alat dan } \\
\quad \text { teknik untuk pengembangan perangkat lunak aplikasi }\end{array}$ \\
\hline
\end{tabular}




\begin{tabular}{|c|c|c|}
\hline No & Jenis Tenaga Teknis & Rincian \\
\hline & & $\begin{array}{l}\text { serta keahlian dalam menggunakan komputer. } \\
\text { Pengetahuan teknis yang harus dimiliki antara lain } \\
\text { pengetahuan tentang perangkat keras, teknologi } \\
\text { komunikasi data, database engine, database } \\
\text { administrator, sistem operasi, utiliti dan paket-paket } \\
\text { perangkat lunak lainnya. } \\
\text { Memiliki kemampuan dalam merancang design dari } \\
\text { database program aplikasi dan berkoordinasi dengan } \\
\text { sistem analis dan programmer dalam perancangan } \\
\text { tersebut. } \\
\text { Memiliki kemampuan teknis dalam merancang serta } \\
\text { membangun database tertentu sesuai dengan } \\
\text { software atau aplikasi yang ditangani. } \\
\text { Memiliki kemampuan dalam melakukan perbaikan } \\
\text { atau bug pada table-table, query maupun relation } \\
\text { dalam database yang bermasalah. }\end{array}$ \\
\hline 4 & Programmer & $\begin{array}{l}\text { Pendidikan: } \\
\text { - } \quad \text { Memiliki tingkat pendidikan minimal D3 dengan } \\
\text { keahlian bidang Telematika (Sistem Informasi/ } \\
\text { Teknologi Informasi/ Sarjana Komputer/ Teknik } \\
\text { Elektro). } \\
\text { Uraian Tugas: } \\
\text { - } \\
\text { Memiliki keahlian teknis dalam penggunaan alat dan } \\
\text { teknik untuk pengembangan perangkat lunak aplikasi } \\
\text { serta keahlian dalam menggunakan komputer. } \\
\text { Pengetahuan teknis yang harus dimiliki antara lain } \\
\text { pengetahuan tentang perangkat keras, teknologi } \\
\text { komunikasi data, bahasa-bahasa pemrograman, } \\
\text { sistem operasi, utiliti dan paket-paket perangkat } \\
\text { lunak lainnya. } \\
\text { Memiliki kemampuan dalam merancang spesifikasi } \\
\text { dari program aplikasi dan berkoordinasi dengan } \\
\text { sistem analis dalam perancangan tersebut. } \\
\text { Memiliki kemampuan teknis dalam penggunaan } \\
\text { bahasa pemrograman tertentu sesuai dengan } \\
\text { software atau aplikasi yang ditangani. } \\
\text { Memiliki kemampuan dalam melakukan perbaikan } \\
\text { atau bug pada software/aplikasi yang bermasalah. }\end{array}$ \\
\hline 5 & Operator Komputer & $\begin{array}{l}\text { Pendidikan: } \\
\text { - } \quad \text { Umum } \\
\text { Uraian Tugas: } \\
\text { - } \quad \text { Kemampuan melakukan input data. Operator harus } \\
\text { memiliki kemampuan membuat dokumentasi } \\
\quad \text { pengujian sistem dengan menginput sejumlah data. } \\
\quad \text { Selain itu operator membuat laporan untuk proses } \\
\quad \text { penginputan data yang bermasalah. Tidak ada ruang }\end{array}$ \\
\hline
\end{tabular}




\begin{tabular}{|c|c|c|}
\hline No & Jenis Tenaga Teknis & Rincian \\
\hline & & $\begin{array}{l}\text { untuk kesalahan karena itu akan mempengaruhi } \\
\text { seluruh proses pengembangan sistem. }\end{array}$ \\
\hline 6 & Administrator & $\begin{array}{l}\text { Pendidikan: } \\
\text { - Umum } \\
\text { Uraian Tugas: } \\
\text { - } \quad \text { Bertanggung jawab untuk mengurus, melengkapi dan } \\
\text { menyelesaikan dokumen-dokumen yang diperlukan } \\
\text { dalam kegiatan administrasi pekerjaan dengan pihak } \\
\text { pemberi pekerjaan. }\end{array}$ \\
\hline
\end{tabular}

Berdasarkan kebutuhan minimal dari sumber daya manusia yang diperlukan dalam proses pengembangan sistem E-PHR (KBS Vision dan KBS Mobile), maka dapat dilihat bahwa Dinas Kesehatan belum bisa melakukannya secara sendiri. Oleh sebab itu, Dinas Kesehatan dapat bekerjasama dengan Dinas Komunikasi dan Informasi dalam proses pengembangan KBS Vision dan KBS Mobile. Hal ini dikarenakan sumber daya manusia yang dimiliki oleh Dinas Komunikasi dan Informasi Kabupaten Badung sudah tersedia dan dirasa cukup mampu untuk mengembangkan KBS-Vision dan KBS Mobile. Apabila langkah ini diambil oleh Dinas Kesehatan, maka dana yang diperlukan untuk proses pengembangan sistem bisa lebih murah dan koordinasi bisa lebih mudah karena masih dalam lingkup OPD.

Meskipun Dinas Komunikasi dan Informasi Kabupaten Badung sudah memiliki sumber daya manusia yang bisa mengembangkan suatu sistem informasi, tetapi perlu diperhatikan bahwa sistem E-PHR tidak sederhana. Hal ini dikarenakan sistem E-PHR berkaitan dengan data kesehatan yang kompleks, serta melibatkan transaksi digital yang besar. Berkaitan dengan hal tersebut, Dinas Komunikasi dan Informasi belum memiliki pengalaman terkait pengelolaan data kesehatan yang begitu besar serta kompleks, dengan tingkat keamanan data yang tinggi. Oleh sebab itu, perlu dilakukan pembahasan lebih lanjut antara Dinas Kesehatan dengan Dinas Komunikasi dan Informasi terkait dengan mekanisme dan SOP pengelolaan sistem EPHR yang akan dikembangkan.

Selain dikembangkan oleh Dinas Komunikasi dan Informasi Kabupaten Badung, alterative lainnya adalah melalui kerjasama dengan pihak ketiga yang sudah berpengalaman menjadi developer sistem 
informasi. Apabila langkah ini diambil oleh Dinas Kesehatan, maka perlu memerhatikan sistem kontrak terkait kepemilikan sistem, akses data, serta mekanisme pemeliharaan sistem apabila terjadi masalah/kendala. Selain itu, bekerjasama dengan pihak ketiga juga menyebabkan dana yang dikeluarkan untuk pengembangan KBS Vision dan KBS Mobile menjadi lebih besar.

\section{Dikembangkan bersama dengan BPJS Kesehatan}

Selain alternative pengembangan sistem melalui Dinas Komunikasi dan Informasi serta melalui pihak ketiga, alternative pengembangan KBS Vision dan KBS Mobile dapat dilakukan melalui kerjasama dengan pihak BPJS. Jika dilihat dari pengalaman pengelolaan data kesehatan, BPJS sudah terbukti mampu melakukan pengembangan maupun pengelolaan sistem informasi kesehatan, seperti pada P-Care, V-Claim, dan Mobile JKN. Apabila Dinas Kesehatan memilih BPJS sebagai mitra pengembangan sistem, maka perlu diperhatikan apakah pihak BPJS bersedia bekerjasama dalam pengembangan KBS Vision dan KBS Mobile, di sisi lain BPJS juga sudah memiliki sistem yang mirip dengan KBS Vision dan KBS Mobile. Alternatif lainnya adalah E-PHR yang akan dikembangkan di Badung bisa disisipkan pada sistem yang sudah dimiliki oleh BPJS, seperti penyempurnaan fitur PCare, V-Claim, dan Mobile JKN sesuai dengan kebutuhan layanan. Jika Dinas Kesehatan memilih langkah ini, perlu dipertimbangkan apakah nantinya EPHR yang dikembangkan ini sudah sesuai dengan brand mark Pemerintah Kabupaten Badung yaitu mempertahankan nama KBS, atau dapat digantikan dengan penamaan BPJS.

\section{Dikembangkan oleh pihak ketiga (pengembang swasta)}

Selain alternative dikembangkan secara mandiri atau dengan bermitra dengan BPJS, pemerintah daerah Kabupaten Badung juga dapat memilih bermitra dengan pihak ketiga dari swasta sebagai pengembang system. Bermitra dengan pengembang swasta memiliki keunggulan dari segi fleksibilitas regulasi. Seperti diketahui, sebagai institusi negara BPJS terikat pada peraturan perundang-undangan dalam aktivitasnya dan saat ini belum terdapat kepastian mengenai regulasi mengenai menempatkan BPJS sebagai vendor atau pengembang system informasi untuk instansi pemerintah lain, dalam hal ini pemerintah daerah Kabupaten Badung. 
Dalam menghadapi ini, bermitra dengan pihak swasta dapat dipertimbangkan.

Kompetensi pihak swasta dalam pengembangan system informasi kesehatan juga dapat diperhitungkan. Saat ini sudah cukup banyak terdapat perusahaan-perusahaan pengembangan system informasi yang terspesialisasi dalam bidang system informasi kesehatan. Seperti diketahui e-Puskesmas sendiri merupakan system yang dikembangkan oleh mitra swasta yaitu PT Infokes Indonesia. Selain itu juga terdapat beberapa perusahaan start-up yang bergerak dalam bidang teknologi informasi kesehatan seperti Medi-Call atau HeloDoc yang berpengalaman mengembangkan aplikasi atau system informasi dalam bidang layanan kesehatan.

Akan tetapi, opsi ini juga harus memperhitungkan pengalaman mengenai kendala dalam melakukan bridging antara system yang dikembangkan dan dikelola swasta dengan system BPJS. Perencanaan yang matang harus dipertimbangkan untuk mengatasi kendala kurangnya akses komunikasi serta sumber daya untuk melakukan update program yang mampu mengikuti regulasi BPJS dan Kementerian Kesehatan sehingga dapat mempertahankan bridging dengan BPJS yang sudah terjadi lebih dulu dalam pengelolaan e-Puskesmas. 


\section{Ucapan Terima Kasīh}

Kajian ini tidak akan dapat terlaksana tanpa kerja sama berbagai pihak yang tidak dapat disebutkan satu per satu. Ucapan terima kasih terkhusus kami sampaikan kepada dr. Putu Ariyani, MIH dan Hari Mulyawan, S.Kom, MPH yang telah berperan dalam pengumpulan data kualitatif primer dalam kajian ini. Selain itu kami juga mengucapkan terima kasih yang sebesar-besarnya kepada seluruh jajaran staf Dinas Kesehatan Kabupaten Badung, Dinas Komunikasi dan Informasi Kabupaten Badung, BPJS Kesehatan, serta masyarakat Desa Carangsari dan Desa Kuta yang telah meluangkan waktu dan pikiran sebagai sumber data kualitatif primer dalam kajian ini. 


\section{Daitar Pustaka}

ADHA, A. D. H. A. (2015) Shared Health Summary - CDA Implementation Guide v1.4 - Australian Digital Health Agency. Available at: https://www.digitalhealth.gov.au/implementationresources/clinical-documents/EP-2397-2017/NEHTA-1840-2015 (Accessed: 2 December 2019).

Ahmadi, M. and Aslani, N. (2018) 'Capabilities and advantages of cloud computing in the implementation of electronic health record', Acta Informatica Medica. The Academy of Medical Sciences of Bosnia and Herzegovina, 26(1), p. 24.

AHMC, A. H. M. C. (2008) National E-Health and Information Principal Committee Draft National E-Health Strategy. Available at: www.deloitte.com.au. (Accessed: 2 December 2019).

Amir, N. (2019) 'Perlindungan Hukum Kerahasiaan Data Pasien Dalam Rekam Medik Elektronik'.

Asosiasi Penyelenggara Jasa Internet Indonesia (APJII) (2017) 'Penetrasi dan Prilaku Pengguna Internet Indonesia, 2016 Survey'.

Bednarczyk, R. A. et al. (2017) 'ReadyVax: A new mobile vaccine information app', Human vaccines \& immunotherapeutics. Taylor \& Francis, 13(5), pp. 1149-1154.

Bott, 0. J. (2004) 'The electronic health record: Standardization and implementation', in 2nd OpenECG Workshop, Berlin, Germany, pp. 5760.

Bush, J. et al. (2017) 'Impact of a mobile health application on user engagement and pregnancy outcomes among Wyoming Medicaid members', Telemedicine and e-Health. Mary Ann Liebert, Inc. 140 Huguenot Street, 3rd Floor New Rochelle, NY 10801 USA, 23(11), pp. 891-898.

Cannaby, S. et al. (2004) 'The cost benefit of electronic patient referrals in Denmark: summary report', Stud Health Technol Inform, 100, pp. 
Gunter, T. D. and Terry, N. P. (2005) 'The emergence of national electronic health record architectures in the United States and Australia: models, costs, and questions', Journal of medical Internet research. JMIR Publications Inc., Toronto, Canada, 7(1), p. e3.

Hanna, L. et al. (2017) 'Patient perspectives on a personally controlled electronic health record used in regional Australia: "I can be like my own doctor"', Health Information Management Journal. Sage Publications Sage UK: London, England, 46(1), pp. 42-48.

Häyrinen, K., Saranto, K. and Nykänen, P. (2008) 'Definition, structure, content, use and impacts of electronic health records: a review of the research literature', International journal of medical informatics. Elsevier, 77(5), pp. 291-304.

Hilvert, J. (2013) NEHTA shrugs off health records patent threat - Training \& Development - Networking - Software - Storage - iTnews. Available at: https://www.itnews.com.au/news/nehta-shrugs-off-healthrecords-patent-threat-333167 (Accessed: 2 December 2019).

Hughson, J. P. et al. (2018) 'The Rise of Pregnancy Apps and the Implications for Culturally and Linguistically Diverse Women: Narrative Review', JMIR mHealth and uHealth. JMIR Publications Inc., Toronto, Canada, 6(11), p. e189.

ISO, I. S. O. (2012) ISO/TR 14292:2012(en), Health informatics - Personal health records - Definition, scope and context. Available at: https://www.iso.org/obp/ui/\#iso:std:iso:tr:14292:ed-1:v1:en (Accessed: 2 December 2019).

Jian, W.-S. et al. (2011) 'The Taiwanese method for providing patients data from multiple hospital EHR systems', Journal of Biomedical Informatics. Elsevier, 44(2), pp. 326-332.

Kaelber, D. and Pan, E. C. (2008) 'The value of personal health record (PHR) systems', in AMIA Annual Symposium Proceedings. American Medical Informatics Association, p. 343.

Kasteren, Y. V. A. N. et al. (2017) 'Consumer perspectives on MyHealth 
Record: A review', in Integrating and Connecting Care: Selected Papers from the 25th Australian National Health Informatics Conference (HIC 2017). IOS Press, p. 146.

Kierkegaard, P. (2013) 'eHealth in Denmark: a case study', Journal of medical systems. Springer, 37(6), p. 9991.

Kolachalam, S. (2006) 'eHealth in Australia', IN INTERNATIONAL TELEMEDICINE AND eHEALTH.

Lee, M. et al. (2018) 'Mobile app-based health promotion programs: a systematic review of the literature', International journal of environmental research and public health. Multidisciplinary Digital Publishing Institute, 15(12), p. 2838.

Librianti, L., Rumenengan, G. and Hutapea, F. (2019) 'Analisa Pengisian Rekam Medis Dalam Rangka Proses Kelengkapan Klaim BPJS Di RSUD dr. Chasbullah Abdulmadjid Kota Bekasi 2018', Jurnal Bidang IImu Kesehatan, 9(1), pp. 50-61.

Lupton, D. (2019) 'II'd like to think you could trust the government, but I don't really think we can": Australian women's attitudes to and experiences of My Health Record', Digital health. SAGE Publications Sage UK: London, England, 5, p. 2055207619847017.

Muhammed, I. and Wickramasinghe, N. (2017) 'User Perceptions and Expectations of the Personally Controlled Electronic Health Record (PCEHR): A Case Study of Australia's e-health Solution', in Proceedings of the 50th Hawaii International Conference on System Sciences.

MyHR

(2019a) Homepage.

Available

at: https://www.myhealthrecord.gov.au/ (Accessed: 2 December 2019).

MyHR (2019b) Remove, restrict or hide information / My Health Record. Available at: https://www.myhealthrecord.gov.au/help/removerestrict-hide (Accessed: 2 December 2019).

NEHTA (2016) Evolution of eHealth in Australia - Achievements, lessons, and opportunities - Australian Digital Health Agency. Available at: 
https://www.digitalhealth.gov.au/about-theagency/publications/reports/benefit-and-evaluationreports/evolution-of-ehealth-in-australia-achievements-lessonsand-opportunities (Accessed: 2 December 2019).

Nøhr, C. et al. (2017) 'Nationwide citizen access to their health data: analysing and comparing experiences in Denmark, Estonia and Australia', BMC health services research. BioMed Central, 17(1), p. 534.

Pearce, C. and Bainbridge, M. (2014) 'A personally controlled electronic health record for Australia', Journal of the American Medical Informatics Association. BMJ Publishing Group BMA House, Tavistock Square, London, WC1H 9JR, 21(4), pp. 707-713.

Quaini, T. et al. (2018) 'A MODEL FOR BLOCKCHAIN-BASED DISTRIBUTED ELECTRONIC HEALTH RECORDS.', IADIS International Journal on WWW/Internet, 16(2).

Rabin, C. and Bock, B. (2011) 'Desired features of smartphone applications promoting physical activity', Telemedicine and e-Health. Mary Ann Liebert, Inc. 140 Huguenot Street, 3rd Floor New Rochelle, NY 10801 USA, 17(10), pp. 801-803.

Rau, H.-H. et al. (2010) 'Developing electronic health records in Taiwan', IT professional. IEEE, 12(2), pp. 17-25.

Reisman, M. (2017) 'EHRs: the challenge of making electronic data usable and interoperable', Pharmacy and Therapeutics. MediMedia, USA, 42(9), p. 572.

Robert, M. (no date) My Health Record: Deleting personal information from databases is harder than it sounds. Available at: https://theconversation.com/my-health-record-deleting-personalinformation-from-databases-is-harder-than-it-sounds-100962 (Accessed: 2 December 2019).

Shah, S. et al. (2008) 'A cost model for personal health records (PHRs)', in AMIA Annual Symposium Proceedings. American Medical Informatics Association, p. 657. 
Showell, C. (2017) 'Barriers to the use of personal health records by patients: a structured review', PeerJ. PeerJ Inc., 5, p. e3268.

Steele, R., Min, K. and Lo, A. (2012) 'Personal health record architectures: technology infrastructure implications and dependencies', Journal of the American Society for Information Science and Technology. Wiley Online Library, 63(6), pp. 1079-1091.

Sudirahayu, I. and Harjoko, A. (2016) 'Analisis Kesiapan Penerapan Rekam Medis Elektronik Menggunakan DOQ-IT di RSUD Dr. H. Abdul Moeloek Lampung', Journal of Information Systems for Public Health, 1(2), pp. 35-43.

Sudjana, S. (2017) 'Aspek Hukum Rekam Medis atau Rekam Medis Elektronik sebagai Alat Bukti Dalam Transaksi Teurapetik', Veritas et Justitia, 3(2), pp. 359-383.

Sundhed.dk (2019) Sundhed.dk is the unified Danish eHealth Portal providing both access to and information about all the Danish Healthcare Services. Available at: https://www.sundhed.dk/borger/service/om-sundheddk/ehealthin-denmark/background/ (Accessed: 2 December 2019).

Tang, P. C. et al. (2006) 'Personal health records: definitions, benefits, and strategies for overcoming barriers to adoption', Journal of the American Medical Informatics Association. BMJ Group BMA House, Tavistock Square, London, WC1H 9JR, 13(2), pp. 121-126.

Vance, B. et al. (2015) 'Benefits and barriers for adoption of personal health records'.

VicHealth (2019) Healthy living apps. Available at: https://www.vichealth.vic.gov.au/media-and-resources/vichealthapps (Accessed: 2 December 2019).

WHO (2016) FROM INNOVATION TO IMPLEMENTATION eHealth in the WHO European Region. Available at: http://www.euro.who.int/en/ehealth (Accessed: 2 December 2019). 
Revolusi Industri 4.0 membawa konsep-konsep seperti big data dan pemberdayaan individual melalui personalized medicine ke dalam ilmu kesehatan. Konsep-konsep ini dikejawantahkan dalam bentuk rekam kesehatan elektronik atau electronic personal health record (E-PHR). Dalam kajian ini penulis menjabarkan mengenai E-PHR, keuntungan, serta fasilitator dan kendala penerapannya. Penulis juga mengembangkan sebuah prototipe model sistem E-PHR yang dapat diterapkan untuk konteks Kabupaten Badung di Provinsi Bali, Indonesia.
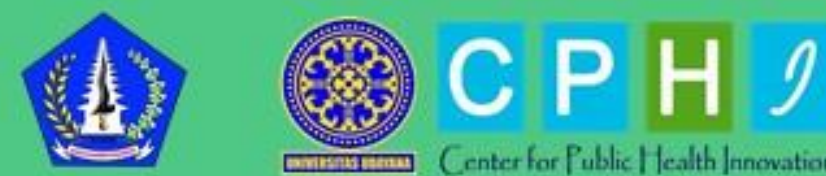

Center for Public / lealth Innovation

(C) CENTER FOR PUBLIC HEALTH INNOVATION, BALI, INDONESIA, 2019

ISBN 978-623-97473-2-9 (PDF)

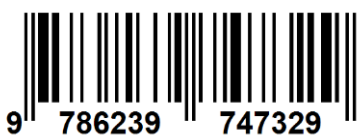

